\title{
More than two decades of research on insect neuropeptide GPCRs: an overview
}

\author{
Jelle Caers, Heleen Verlinden, Sven Zels, Hans Peter Vandersmissen, Kristel Vuerinckx and \\ Liliane Schoofs*
}

Animal Physiology and Neurobiology, Department of Biology, Zoological Institute, KU Leuven, Leuven, Belgium

\section{Edited by:}

Hubert Vaudry, University of Rouen, France

Reviewed by:

Dick R. Nässel,

Stockholm University, Sweden

Hoffmann Klaus H., University of

Bayreuth, Germany

*Correspondence:

Liliane Schoofs, Department

of Biology, Research Group of

Functional Genomics and

Proteomics, Naamsestraat 59,

KU Leuven, 3000 Leuven, Belgium.

e-mail: liliane.schoofs@

bio.kuleuven.be
This review focuses on the state of the art on neuropeptide receptors in insects. Most of these receptors are G protein-coupled receptors (GPCRs) and are involved in the regulation of virtually all physiological processes during an insect's life. More than 20 years ago a milestone in invertebrate endocrinology was achieved with the characterization of the first insect neuropeptide receptor, i.e., the Drosophila tachykinin-like receptor. However, it took until the release of the Drosophila genome in 2000 that research on neuropeptide receptors boosted. In the last decade a plethora of genomic information of other insect species also became available, leading to a better insight in the functions and evolution of the neuropeptide signaling systems and their intracellular pathways. It became clear that some of these systems are conserved among all insect species, indicating that they fulfill crucial roles in their physiological processes. Meanwhile, other signaling systems seem to be lost in several insect orders or species, suggesting that their actions were superfluous in those insects, or that other neuropeptides have taken over their functions. It is striking that the deorphanization of neuropeptide GPCRs gets much attention, but the subsequent unraveling of the intracellular pathways they elicit, or their physiological functions are often hardly examined. Especially in insects besides Drosophila this information is scarce if not absent. And although great progress made in characterizing neuropeptide signaling systems, even in Drosophila several predicted neuropeptide receptors remain orphan, awaiting for their endogenous ligand to be determined. The present review gives a précis of the insect neuropeptide receptor research of the last two decades. But it has to be emphasized that the work done so far is only the tip of the iceberg and our comprehensive understanding of these important signaling systems will still increase substantially in the coming years.

Keywords: insects, neuropeptides, G protein-coupled receptors, signal transduction, neurobiology

\section{INTRODUCTION}

The class of Insecta, which consists of more than 30 orders, forms the most diverse animal group on earth. With about one million documented species and presumably $10-30$ million awaiting to be described, insects probably account for $50-70 \%$ of all existing animals (Scherkenbeck and Zdobinsky, 2009; Bellés, 2010; Van Hiel et al., 2010). Basically all the physiological processes during an insect's life cycle are regulated by neuropeptides, including developmental processes, behavioral functions, metabolic events and reproduction. As such, neuropeptides are the largest (very versatile) class of extracellular signaling molecules that are involved in communication between insect cells (Gäde and Goldsworthy, 2003; Meeusen et al., 2003; Claeys et al., 2005a). The insect neuropeptides and their actions have extensively been reviewed in the past (Nässel, 2002; Gäde and Auerswald, 2003; Gäde and Goldsworthy, 2003; Meeusen et al., 2003; Altstein, 2004; Gäde, 2004; Isaac et al., 2004; Simonet et al., 2004; Claeys et al., 2005a; Coast and Garside, 2005; Ewer, 2005; Predel and Wegener, 2006; Mertens et al., 2007; Stay and Tobe, 2007; De Loof, 2008; Audsley and Weaver, 2009; Scherkenbeck and Zdobinsky, 2009; Verleyen et al., 2009; Verlinden et al., 2009; Weaver and Audsley, 2009; Altstein and Nässel, 2010; Bendena, 2010; Nässel and Winther, 2010; Van Hiel et al., 2010; Van Loy et al., 2010; Nässel and Wegener, 2011; Herrero, 2012; Spit et al., 2012; Taghert and Nitabach, 2012).

Neuropeptides exert their physiological functions by interacting with specific signal-transducing membrane receptors, resulting in intracellular responses (Zupanc, 1996). Most of these neuropeptide receptors belong to the $\mathrm{G}$ protein-coupled receptors (GPCRs), the largest family of cell surface proteins. However, there are some exceptions like the prothoracicotropic hormone (PTTH), which executes its role in metamorphosis through the activation of a receptor tyrosine kinase (RTK) (Rewitz et al., 2009). Most of the insulin-like peptides (ILPs) also interact with RTKs (Fernandez et al., 1995; Graf et al., 1997; Brogiolo et al., 2001; Wheeler et al., 2006; Wen et al., 2010; Iga and Smagghe, 2011). The eclosion hormone (EH), involved in ecdysis, interacts with a membrane-bound guanylate cyclase receptor (Chang et al., 2009) as does the neuropeptide-like precursor peptide 1 (NPLP1) (Overend et al., 2012). 
The functional characterization of the first insect neuropeptide receptor, the Drosophila melanogaster tachykinin-like receptor (DTKR) took place in 1991 (Li et al., 1991). Subsequently, another Drosophila tachykinin-like receptor (NKD) (Monnier et al., 1992) and a neuropeptide Y (NPY)-like receptor (Li et al., 1992) were identified. The latter has recently been deorphanized as the Drosophila RYamide receptor (Collin et al., 2011; Ida et al., 2011a). In the following years only a few more insect GPCRs were cloned, e.g., the diuretic hormone receptors of Manduca sexta and Acheta domesticus (Reagan, 1994, 1996), the Drosophila gonadotropinreleasing hormone receptor (Hauser et al., 1998), which later on was deorphanized as an adipokinetic hormone (AKH) receptor (Staubli et al., 2002) and the Drosophila allatostatin (AST) receptor (DAR-1) (Birgül et al., 1999).

The real breakthrough in the field of insect neuropeptide receptor research came with the publication of the Drosophila genome in 2000 (Adams et al., 2000). This opened the opportunity to predict receptors based on genomic data (Hewes and Taghert, 2001), which clearly boosted the receptor deorphanization rate. At present, 35 GPCRs are functionally characterized in Drosophila. One receptor (Dmel $\backslash \mathrm{SPR}$ ) is activated by seemingly different neuropeptides, the myoinhibitory peptide (MIP) and the sex peptide SP. The others mainly respond to one neuropeptide type, which underlines the specificity of the receptor/ligand couples. Another 14 GPCRs are predicted to be involved in neuropeptide signaling pathways, but their ligands are still unknown and therefore they are classified as "orphan" receptors (Table 1) (Meeusen et al., 2003; Hauser et al., 2006, 2008; Clynen et al., 2010a). In section "Methuselah (CG6936) and Methuselah-like Receptors" the methuselah receptor is also briefly discussed. In spite the fact that several studies have been performed on this receptor, it still is not clear if it is really a neuropeptide receptor and if the stunted gene really encodes for its endogenous ligands.

Despite the diversity in their endogenous ligands, GPCRs have been rather well conserved during evolution. This has facilitated the search for neuropeptide receptors in newly released genomes like those of Apis mellifera (Hauser et al., 2006), Tribolium castaneum (Hauser et al., 2008), and Bombyx mori (Yamanaka et al., 2008; Fan et al., 2010). Research in other insects also revealed a set of new neuropeptide signaling systems that are not present in Drosophila, e.g., AKH/corazonin-related peptide (ACP) discovered in Anopheles gambiae (Hansen et al., 2010), allatotropin (AT) discovered in B. mori (Yamanaka et al., 2008), and inotocin discoverd in T. castaneum (Stafflinger et al., 2008) (Table 1).

Hitherto, 149 insect genome projects are either completed or in progress (http://www.ncbi.nlm.nih.gov/sites/entrez? $\mathrm{db}=$ bioproject) and in 2011 , the $\mathrm{i} 5 \mathrm{~K}$ project was initiated, which aims to sequence 5000 insect genomes in the next 5 years (Robinson et al., 2011). With this overload of genomic information coming up, we intend to give the reader a clear overview of what is currently known on insect neuropeptide receptors. First, we will discuss some general characteristics of GPCRs and the deorphanizing strategies. Next, we will highlight the area of peptidomics, which facilitated the prediction and detection of ligands enormously, followed by a genetics part to discuss some commonly used tools to unravel the physiological functions of the neuropeptide-receptor systems. Thereafter, the current status of the insect neuropeptide GPCRs will be reviewed. To conclude, a short discussion about the importance of neuropeptide research in insects will be given.

\section{G PROTEIN-COUPLED RECEPTORS}

Several GPCR-(sub)families originated prior to the divergence of protostomian and deuterostomian animals. This led to a great diversification in chemical specificity to external stimuli like neuropeptides, glycoproteins, nucleotides, biogenic amines, odorants, taste ligands, and photons. Although GPCRs do not share any overall sequence homology, they do expose a similar topographical structure which is remarkably well conserved during evolution. They are typically composed of seven transmembrane (7TM) $\alpha$-helices, each consisting of 20-30 hydrophobic amino acids, and three extracellular and intracellular loops connecting the different helices. The N-terminus is located at the extracellular site and often possesses several glycosylation sites; the C-terminus, on the other hand, is orientated into the cytoplasm and offers some potential phosphorylation sites. The extracellular parts are involved in ligand-specific binding, while the intracellular areas interact with a member of the family of heterotrimeric GTP-binding proteins (G proteins), consisting of an $\alpha-, \beta-$, and $\gamma$-subunit (Bockaert and Pin, 1999). Based on shared sequence motifs, the GPCRs are categorized into at least six subfamilies. The evolutionary relationship between the different families is still unclear because of the lack of significant sequence homology. They probably evolved independently of each other or have adopted the $G$ protein signal transduction pathways through convergent evolution (Brody and Cravchik, 2000; Gether, 2000; Horn et al., 2000). All the neuropeptide GPCRs belong to the rhodopsin-like (family A) or the secretin-like (family B) subfamily.

When a GPCR becomes activated by its ligand, the extracellular signal will be transduced into intracellular physiological responses. An activated receptor will undergo a conformational change, which in turn leads to the activation of the associated $\mathrm{G}$ protein. This promotes the release of GDP from the $\alpha$-subunit, followed by binding of GTP. Next, the GTP-bound $\alpha$-subunit dissociates from the $\beta \gamma$-dimer and both will be released in the cytoplasm. Subsequently, they can interact with their specific effector proteins to elicit cellular signaling pathways. The effector proteins involved depend on the type of the $\alpha$-subunit. The most common $\alpha$-subunits are $\mathrm{G}_{\mathrm{q}}, \mathrm{G}_{\mathrm{s}}$, and $\mathrm{G}_{\mathrm{i} / \mathrm{o}}$. The $\mathrm{G}_{\mathrm{q}}$ subunits interact with phospholipase $C \beta$ (PLC $\beta$ ) in order to initiate the hydrolysis of the membrane-bound phosphoinositolbiphospholipid-bisphosphates resulting in diacylglycerol (DAG) and inositol triphosphate $\left(\mathrm{IP}_{3}\right)$. DAG activates protein kinase $\mathrm{C}(\mathrm{PKC})$ and $\mathrm{IP}_{3}$ mobilizes $\mathrm{Ca}^{2+}$ from intracellular stores like the endoplasmic reticulum. The $\mathrm{G}_{\mathrm{s}}$ and $\mathrm{G}_{\mathrm{i} / \mathrm{o}}$ subunits, respectively, activate or inhibit adenylyl cyclase provoking a subsequent increase or decrease of the cyclic adenosine monophosphate (cAMP) concentration within the cell. The $\mathrm{G}_{\mathrm{s}}$ proteins are also capable of activating $\mathrm{Ca}^{2+}$ channels, while the $\mathrm{G}_{i / \text { o }}$ proteins are able to interact with $\mathrm{K}^{+}$-channels. The intrinsic GTPase activity of $\mathrm{G} \alpha$ induces the hydrolysis of GTP to GDP, resulting in the reassociation of the subunits (Hepler and Gilman, 1992; Lustig et al., 1993; Vanden Broeck, 1996, 2001; Brody and Cravchik, 2000). 


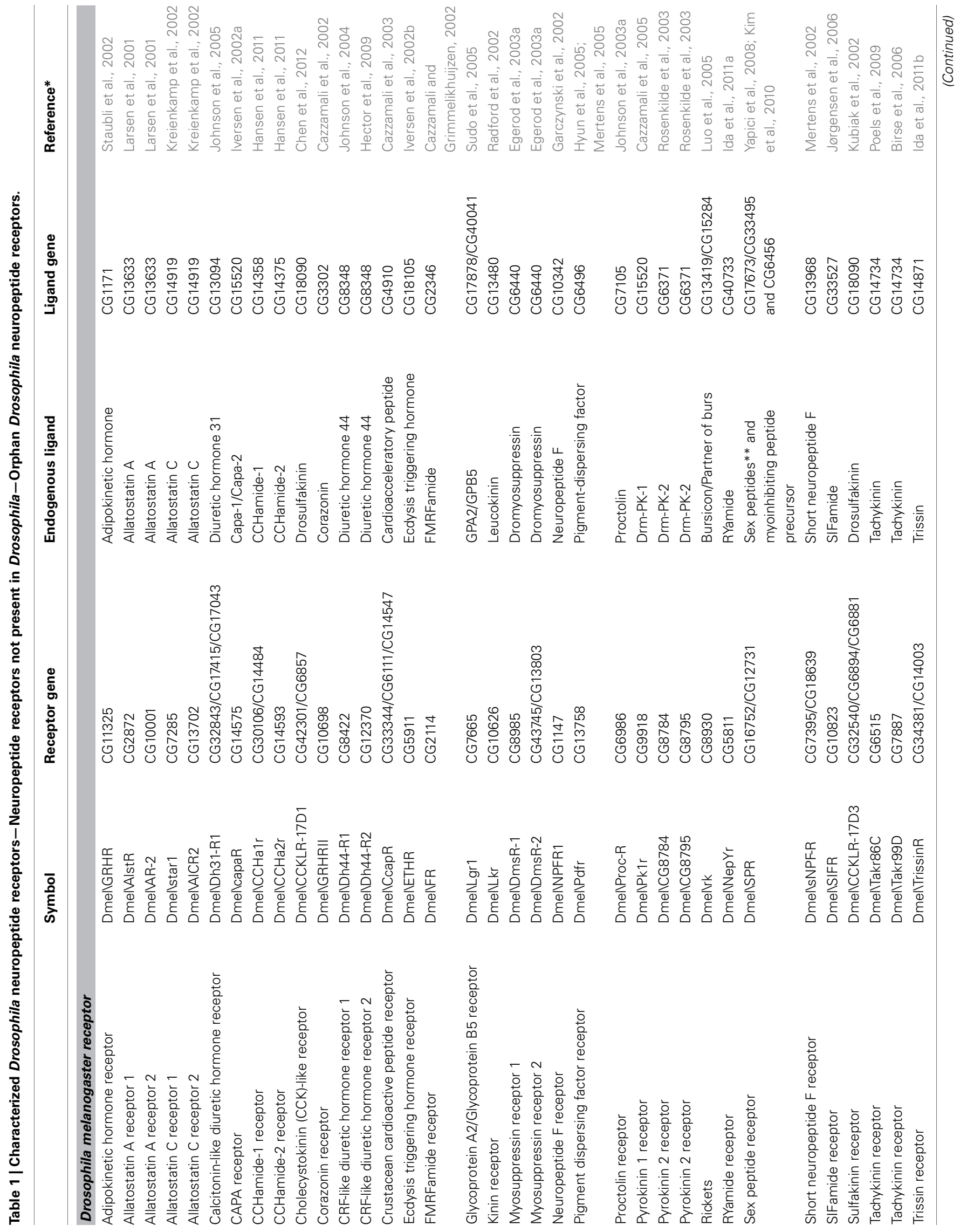




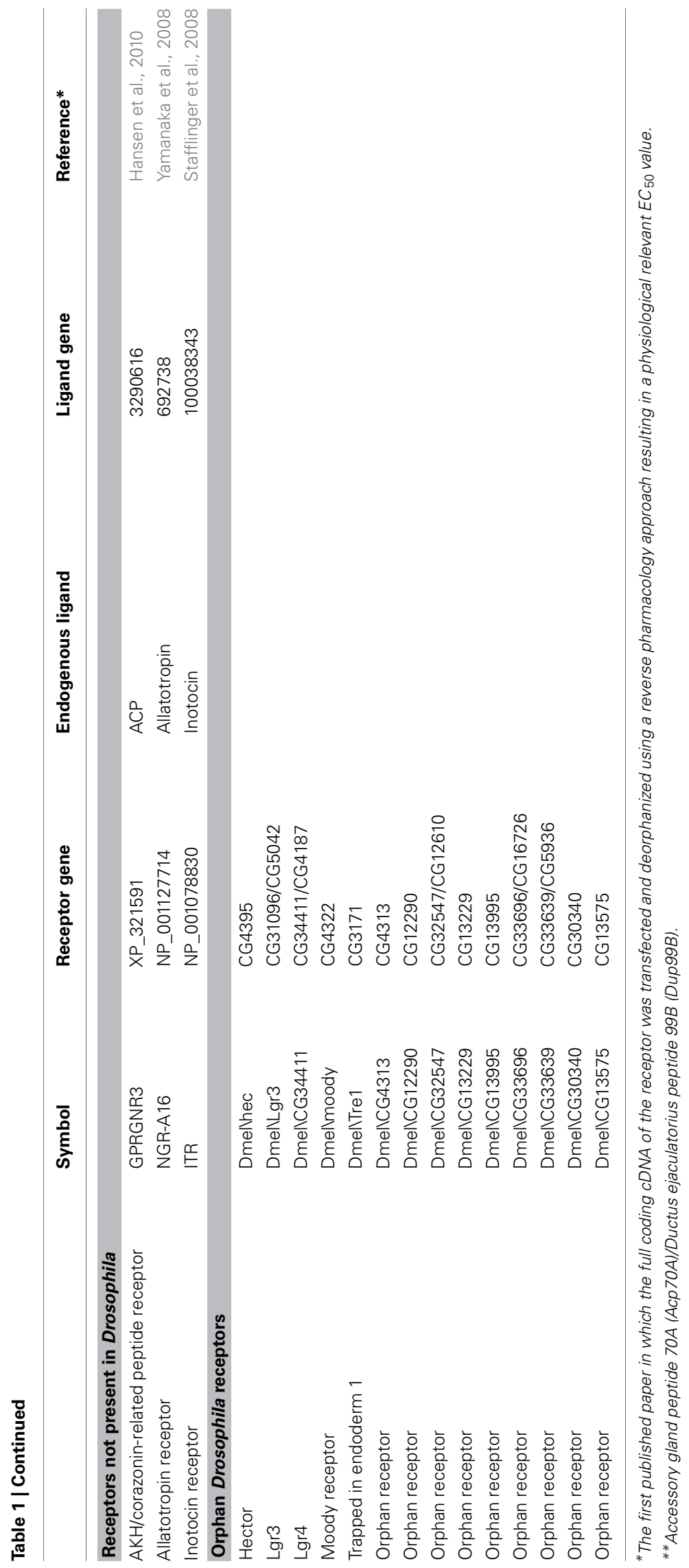




\section{DEORPHANIZING STRATEGIES}

There is a clear distinction between the techniques used to deorphanize receptors before and after the genomic era. In the past, one started with a bioactive ligand, purified from tissue extracts, in order to identify its corresponding receptor (the classic approach). Nowadays, an orphan receptor is used to explore its activating ligand from a library of synthetic compounds consisting of predicted neuropeptides (reverse pharmacology) (Meeusen et al., 2003). This strategy makes use of appropriate cellular expression systems used to express orphan receptors of interest. These systems hold the opportunity to measure one of the many second messenger reporter molecules released after receptor activation. The most commonly used expression systems are mammalian cell lines (Chinese Hamster Ovary [CHO] cells or Human Embryonic Kidney [HEK] 293 cells) and Xenopus oocytes. These are used in the bioluminescence-based assay ( $\mathrm{CHO}$ cells), the fluorescence-based assay (HEK293 cells), the luciferase-based assay (HEK293 cells) and the electrophysiological assay (Xenopus oocytes).

Because it is nearly impossible to predict which kind of $G$ protein interacts with an orphan receptor, a universal tool was required to predict the signaling cascade. This problem was circumvented with the discovery of the promiscuous $G$ protein $\alpha$ subunits $\mathrm{G} \alpha_{16}$ (human) and $\mathrm{G} \alpha_{15}$ (murine). These $\mathrm{G} \alpha$ proteins regulate PLC $\beta$, and possess the ability to interact with most GPCRs and, as such, their signaling pathways are redirected toward the release of $\mathrm{Ca}^{2+}$ (Offermanns and Simon, 1995). Both, the bioluminescence and the fluorescence assay are based on the measurement of the release of intracellular $\mathrm{Ca}^{2+}$ upon receptor activation. The bioluminescence assay makes use of bioluminescent proteins such as aequorine, purified from the jellyfish, Aequoria victoria, that interact with $\mathrm{Ca}^{2+}$ (Prasher et al., 1987; Stables et al., 1997). In the fluorescence assay usually HEK293 cells are charged with a $\mathrm{Ca}^{2+}$ sensitive fluorophore that serves as readout (Bender et al., 2002). The luciferase assay makes use of a reporter gene plasmid consisting of a cAMP response element (CRE) as readout for measuring intracellular cAMP levels (Janssen et al., 2008; Horodyski et al., 2011; Vuerinckx et al., 2011). For the electrophysiological assay, Xenopus oocytes are injected with a mix of the orphan receptor and the $G$ protein gated inwardly rectifying $\mathrm{K}^{+}$(GIRK) channels that are activated upon ligand binding. This leads to subsequent inward $\mathrm{K}^{+}$currents that can be measured (Kofuji et al., 1995; Ho and Murrell-Lagnado, 1999; Ulens et al., 1999).

Besides the use of these heterologous expression systems, one can also make use of a homologous expression system in which the orphan receptor is expressed in Drosophila Schneider-2 (S2) cells (Vanden Broeck et al., 1998). The use of heterologous expression systems, however, prevents that compounds present in an insect extract, or predicted insect ligands would activate endogenous mammalian or amphibian receptors (for reviews, see: Meeusen et al., 2003; Mertens et al., 2004; Beets et al., 2011; Bendena et al., 2012).

\section{NEUROPEPTIDES AND PEPTIDOMICS}

An important feature of the currently used deorphanizing strategies is the ability to screen orphan receptors with compound libraries containing potential neuropeptides. The possibility to create such libraries coincided with the availability of the first whole genome databases. This also launched the era of peptidomics, which encloses the purpose to simultaneously identify and/or visualize all peptides present in a cell, tissue, body liquid, or organism. Peptidomics studies are based on two major elements, the in silico prediction of neuropeptides and the discovery and identification of neuropeptides using mass spectrometric devices (Baggerman et al., 2002; Predel et al., 2004; Wegener et al., 2006).

Endogenous neuropeptides are enclosed in larger preprohormones, mostly between 50 and 500 amino acids long (Baggerman et al., 2005a). They can code for multiple structurally related or unrelated neuropeptides, as well as for just one neuropeptide. The only common feature of preprohormones is the presence of an amino-terminal signal peptide, with exception of a predicted AST CC neuropeptide in Drosophila which has an amino-terminal peptide anchor (Veenstra, 2009a). This peptide is immediately cleaved off after arrival in the endoplasmic reticulum. The residual prohormone undergoes enzymatic cleavage at mono- or dibasic amino acid residues to release the neuropeptides (Hook et al., 2008; Rholam and Fahy, 2009). Most neuropeptides require posttranslational modifications to become bioactive or to improve stability.

Because of the poor sequence conservation between preprohormones and the short length of the neuropeptides, the majority consists only of 4-20 amino acids, their prediction from genome databases is not straightforward. Nevertheless, classical BLAST analyses have revealed 36 neuropeptide genes in D. melanogaster (Hewes and Taghert, 2001; Vanden Broeck, 2001), and 35 in A. gambiae (Riehle et al., 2002). Later on, the combined use of different bioinformatic tools, to overcome the low sensitivity of a BLAST analysis alone, revealed a total of 119 potential neuropeptide-coding genes in Drosophila (Liu et al., 2006; Clynen et al., 2010a). All neuropeptides predicted by these methods can be synthesized to construct synthetic peptide libraries applied in the reverse pharmacology assays.

The bioinformatic predictions, though, do not reveal which neuropeptides are ultimately produced, and endogenous bioactive neuropeptides may be overlooked in the genomic data. The processing of a precursor can also differ during developmental stages or between tissues, and post-translational modifications are hard to predict based on sequence information. Therefore, a biochemical characterization of neuropeptides is necessary. There are several possible peptidomics methods available to provide in these needs, all based on mass spectrometry. The most common tool is a combination of liquid chromatography, tandem mass spectrometry and database mining, which allows the detection and sequencing of low concentrations of neuropeptides from complex mixtures (Clynen et al., 2010b). Mass spectrometry applications led to the discovery of hundreds of neuropeptides. As is often the case, Drosophila peptidomics (Baggerman et al., 2002; Baggermanet al., 2005b; Schoofs and Baggerman, 2003) paved the way for peptidomic studies in other insects, e.g., A. mellifera (Hummon et al., 2006; Boerjan et al., 2010a), Nasonia vitripennis (Hauser et al., 2010), T. castaneum (Li et al., 2008), and Aedes aegypti (Predel et al., 2010). Also in insects with no completely 
sequenced genome, peptidomics may prove useful, e.g., Locusta migratoria (Clynen et al., 2006; for reviews, see: Hummon et al., 2006; Boonen et al., 2008; Menschaert et al., 2010).

\section{FUNCTIONAL GENOMICS}

Upon the characterization of a neuropeptide receptor and its ligand, the question remains which function they possess in a specific organism. These functions can be determined with genetic tools. In the classic approach the phenotype of interest is chosen first and then attempts are made to identify the genes responsible for this phenotype (forward genetics). With the rise of the whole genome era, a tremendous number of genes with unknown functions were identified. This made it possible to start with a gene of interest and to study its function (reverse genetics). Currently, the most used techniques to perform reverse genetics are silencing of genes of interest by RNA interference (RNAi), generating knockouts, and overexpressing specific genes using the GAL4/UAS system.

The generation of loss-of-function phenotypes through the application of RNAi is a fairly new technique as it was described for the first time in 1998 in Caenorhabditis elegans (Fire et al., 1998), immediately followed by a report of RNAi usage in $D$. melanogaster (Kennerdell and Carthew, 1998). RNAi studies are widely used in the field of insect research and have proven to be appropriate to unravel functions of neuropeptides and their receptors in various species (Bellés, 2010; An et al., 2012). There is a genome-wide transgenic RNAi library available for Drosophila, consisting of short gene fragments cloned as inverted repeats and expressed using the binary GAL4/UAS system (Dietzl et al., 2007). The usage of the GAL4/UAS system to perform RNAi experiments becomes also more established in other insects like B. mori (Dai et al., 2008) and T. castaneum (Schinko et al., 2010).

RNAi can not entirely impede the expression of a gene of interest. To generate a complete knockout of a gene, mutagenic or homologous recombination tools are frequently used. Mutagenesis relies on the incorporation of mutations, which can be obtained by the application of chemical mutagenesis or by transposable element mutagenesis, followed by a thorough screen to detect the samples containing mutations in the gene of interest. Homologous recombination is based on the host DNA repair system for the alteration of a target sequence in the genome by a donor sequence. This donor sequence exhibits homology to the target sequence, but contains the desired genetic modifications. The alteration is preceded by the generation of a double strand break in the target or donor sequence, inducing the homologous recombination repair system (for reviews, see: Reumer et al., 2008; Wesolowska and Rong, 2010; An et al., 2012).

Besides studying the effects of a knockdown or a complete knockout of a certain gene, overexpressing a gene can also yield important information about its function. To obtain overexpression, the gene of interest can be coupled to a binary GAL4/UAS system as well.

The previous described techniques to identify, deorphanize and determine the functions of neuropeptide signaling systems are widely applied in insect research, yielding an enormous amount of information. Table 2 summarizes the neuropeptide receptors that have been predicted and/or functionally characterized for a selection of model insects. In the next section we aim to give a brief summary of what is known so far relating to these insect neuropeptide receptors. For convenience all intertitles are accompanied with the corresponding computed gene (CG) numbers of the Drosophila receptors. These numbers were used for genes identified during the annotation of the whole Drosophila genome sequence. For those receptor genes not annotated in Drosophila, the accession number of the receptor gene for the insect in which it was first deorphanized is added.

\section{DEORPHANIZED NEUROPEPTIDE RECEPTORS ADIPOKINETIC HORMONE RECEPTORS (CG11325 ORTHOLOGS)}

The first structural characterization of an AKH neuropeptide was achieved in 1976 (Stone et al., 1976). Currently, around 55 isoforms, derived from various insect species, have been described (Gäde, 2009; Caers et al., 2012; Gäde and Marco, 2012; Jedlička et al., 2012; Malik et al., 2012; Weaver et al., 2012). They consist of $8-10$ amino acids, and are characterized by a blocked $\mathrm{N}$-terminus (pyroglutamate) and C-terminus (amidation) (Gäde and Auerswald, 2003). The main function of AKH is the regulation of the energy metabolism. During energy requiring processes like flight, the AKH neuropeptides are released from the corpora cardiac (CC) and will interact with their receptors, present in the membrane of the fat body adipocytes. This will induce the release of energy rich substrates (lipids, trehalose, or proline) (Lorenz and Gäde, 2009). The kind of substrates released, depends on the coupled $G$ protein. When AKH binds to a $G_{q}$ protein-coupled receptor, glycogen phosphorylase will be activated and trehalose will be set free. If the signaling pathway acts by a $G_{s}$ proteincoupled receptor, triacylglycerol lipase will be activated, resulting in the production of DAG or free fatty acids (Gäde and Auerswald, 2003). The last years it became clear that the function of AKH is not restricted to locomotory activity alone, but that it acts as a general regulator of homeostasis in insects, influencing all energy requiring processes (e.g., egg production, feeding behavior, larval growth, molting, and immune response) (Goldsworthy et al., 2002, 2003; Lorenz, 2003; Lee and Park, 2004; Isabel et al., 2005; Grönke et al., 2007; Bharucha et al., 2008; Lorenz and Gäde, 2009; Arrese and Soulages, 2010; Attardo et al., 2012; Konuma et al., 2012). AKH also serves as an anti-stress hormone in oxidative stress situations (Kodrík et al., 2007; Večeřa et al., 2007; Kodrík, 2008; Huang et al., 2011a).

The AKH receptors (AKHR) are closely related to the ACP receptors and constitute the invertebrate AKH/ACP receptor family. Together with the invertebrate corazonin/gonadotropin releasing hormone $(\mathrm{GnRH})$ receptor family and the vertebrate/protochordate $\mathrm{GnRH}$ receptor family they compose the GnRH receptor superfamily (Lindemans et al., 2011; Roch et al., 2011). The first AKHR was determined in M. sexta by using fat body fractions to ascertain the optimal binding conditions for tritium-labeled Manse-AKH (Ziegler et al., 1995). The Drosophila AKHR was the first to be cloned and was deorphanized by making use of the electrophysiological assay (Park et al., 2002), and its characterization was confirmed by Staubli et al. (2002) using a bioluminescence assay. Later, AKHRs were also identified and characterized in other insect species: Periplaneta americana (Hansen et al., 2006; Wicher et al., 2006a), A. gambiae (Belmont 


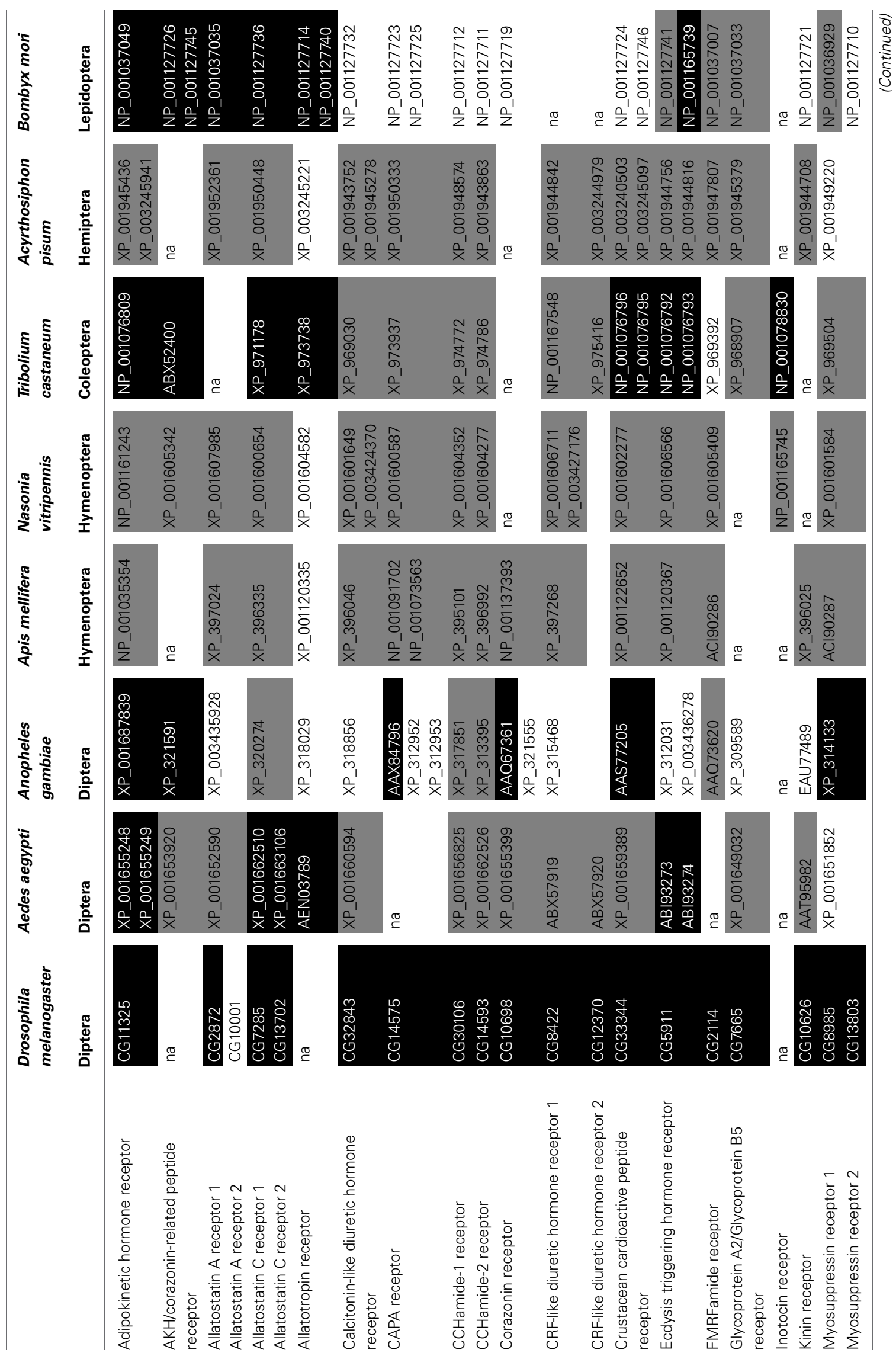




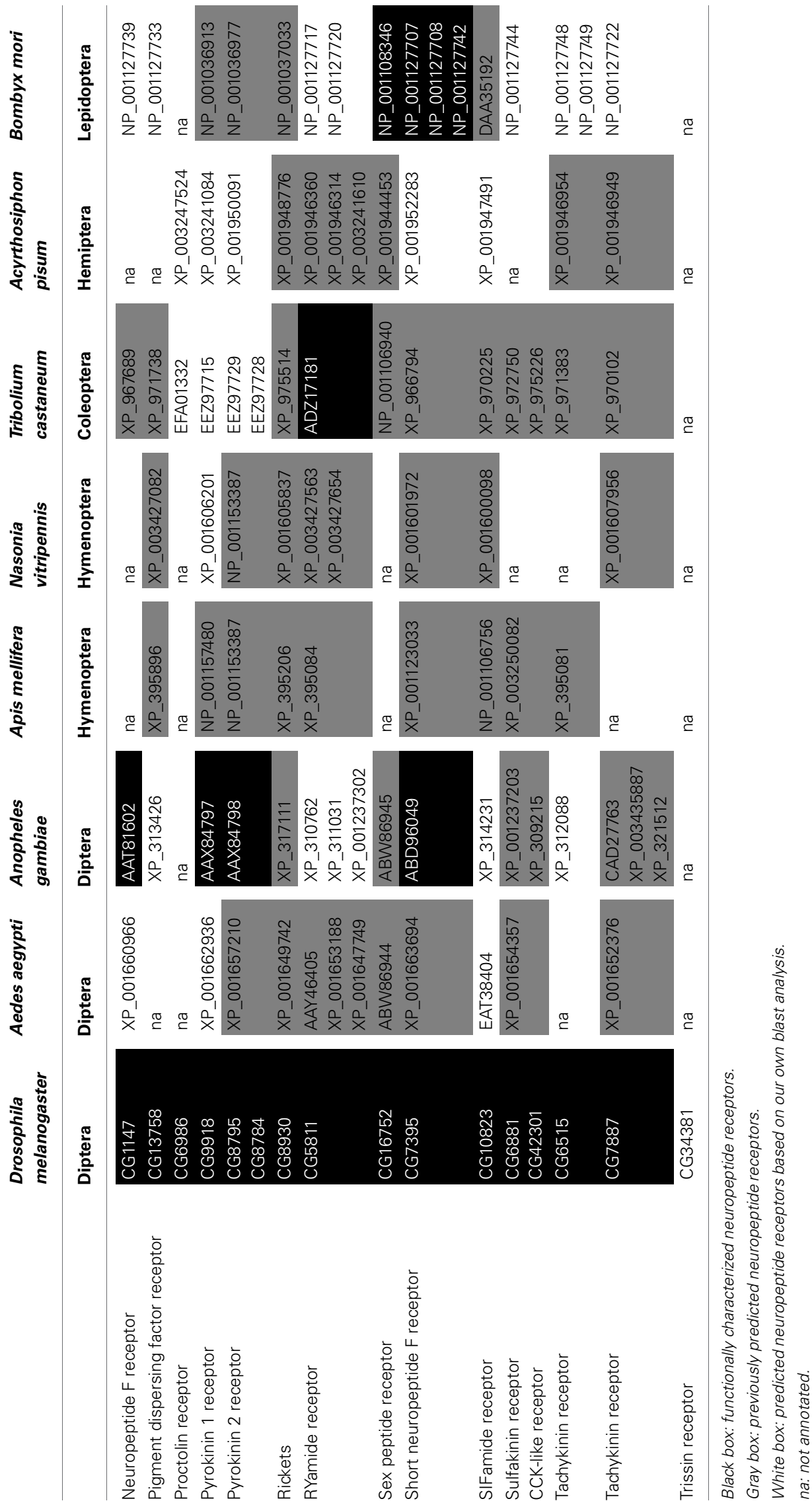


et al., 2006), B. mori (Staubli et al., 2002; Zhu et al., 2009; Huang et al., 2010), and T. castaneum (Li, unpublished data). Two putative AKHR variants have been predicted in A. aegypti (Kaufmann et al., 2009) and one AKHR is identified in the Apis genome (Hauser et al., 2006). However, it remains doubtful if this receptor is really functional in the honeybee, because mass spectrometric techniques have failed to detect the predicted Apis AKH neuropeptide (Veenstra et al., 2012). Besides expression in the fat body (Kaufmann and Brown, 2006; Ziegler et al., 2011), the AKHR is also expressed in various neurons of $P$. americana, including the abdominal dorsal unpaired medial (DUM) neurons, which are responsible for the release of octopamine. As such, octopamine may be the link between elevated AKH-titers and the increase in locomotion (Wicher et al., 2006b, 2007; Verlinden et al., 2010).

\section{ADIPOKINETIC HORMONE/CORAZONIN-RELATED PEPTIDE RECEPTOR (XP_321591 ORTHOLOGS)}

In 2006, an A. gambiae receptor was annotated and cloned that was closely related to the $\mathrm{AKH}$ and corazonin receptors, but could not be activated by these neuropeptides (Belmont et al., 2006). Hansen et al. (2010) detected a neuropeptide closely related to both AKH and corazonin and named it ACP. This neuropeptide was able to activate the receptor expressed in $\mathrm{CHO} / \mathrm{G} \alpha_{16}$ cells in a dose-responsive manner (Hansen et al., 2010). Subsequently, the ACP receptor was also characterized in T. castaneum (Hansen et al., 2010). Recently, two predicted ACP receptors of B. mori (Yamanaka et al., 2008; Hansen et al., 2010) were also characterized, but were indicated as AKHR (Shi et al., 2011). The ACP neuropeptides were in fact already described in L. migratoria (Siegert, 1999) and in A. gambiae (Kaufmann and Brown, 2006), but were classified as AKH neuropeptides with unknown functions. ACP and its receptor are structurally intermediate between the $\mathrm{AKH}$ and corazonin neuropeptides and their receptors, which is a prominent example of receptor/ligand co-evolution. An ancestral receptor and ligand gene have probably duplicated several times followed by mutations and evolutionary selection, leading to three signaling systems. However, the ACP signaling system is absent in all investigated Drosophila species as well as in $A$. mellifera, Acyrthosiphon pisum, Pediculus humanus, and in the crustacean Daphnia pulex, suggesting that it may have been lost several times during arthropod evolution (Hansen et al., 2010). So far no functions are assigned to the ACP signaling system, but the high expression shortly before and after hatching of T. castaneum suggests a role in early larval development (Hansen et al., 2010).

\section{ALLATOSTATIN A RECEPTORS (CG2872 AND CG10001 ORTHOLOGS)}

The endogenous ligands of the AST A receptor are the A-type AST neuropeptides which belong to the group of allatoregulatory neuropeptides together with the B-, and C-type allatostins and the ATs (for a review, see: Weaver and Audsley, 2009) and the recently discovered AST CC neuropeptides (Veenstra, 2009a). Allatoregulatory peptides are named after their ability to either inhibit (ASTs) or stimulate (ATs) juvenile hormone (JH) synthesis (Audsley et al., 2008). The B-type ASTs are also known as myoinhibiting peptides and were found to activate the SP receptor [see section "Sex Peptide/Myoinhibiting Peptide Receptor (CG16752/CG12731 Orthologs)"].

The A-type AST-As, or FGLamides were first isolated of brain extracts of cockroaches (Woodhead et al., 1989; Pratt et al., 1991), and have since been found in every investigated insect species, except for T. castaneum (Li et al., 2008). They are characterized by a conserved (Y/F)XFG(L/I)- $\mathrm{NH}_{2}$ sequence (Hayes et al., 1994; Audsley et al., 1998). AST-As regulate JH biosynthesis in cockroaches, crickets, and termites (Pratt et al., 1989, 1991; Woodhead et al., 1989, 1994; Bellés et al., 1994; Weaver et al., 1994; Lorenz et al., 1995, 1999; Yagi et al., 2005; for a review, see: Stay and Tobe, 2007). A property attributed to all AST-As is myoinhibition of visceral muscles (Hoffmann et al., 1999; Stay, 2000; Aguilar et al., 2003; Weaver and Audsley, 2009; Zandawala et al., 2012). Recently, Drosophila AST-A was linked to food intake and foraging behavior (Hergarden et al., 2012; Wang et al., 2012). In Drosophila, two A-type AST receptors are identified: DAR-1 and DAR-2 (Birgül et al., 1999; Larsen et al., 2001). DAR-1, when expressed in Xenopus oocytes was shown to couple to a G-protein of the $\mathrm{G}_{\mathrm{i} / \mathrm{o}}$ family. When expressed in CHO cells, DAR-1 and -2 are activated by AST-A and mobilize intracellular $\mathrm{Ca}^{2+}$ (Larsen et al., 2001). AST-A receptors were also characterized in P. americana (Auerswald et al., 2001), B. mori (Secher et al., 2001), and Diploptera punctata (Lungchukiet et al., 2008). Northern blot experiments showed that the B. mori receptor is expressed in the midgut of fifth larval instars and to a much lesser extend in the brain (Secher et al., 2001).

\section{ALLATOSTATIN C RECEPTORS (CG7285 AND CG13702 ORTHOLOGS)}

The first C- or PISCF-type AST was characterized in the late pupae of M. sexta. AST-Cs contain a typical C-terminal PISCF$\mathrm{OH}$ sequence, a blocked $\mathrm{N}$-terminus and a disulfide bridge linking Cys-7 and Cys-14 (Kramer et al., 1991). Orthologs are found in other lepidopteran, dipteran and coleopteran species ( $\mathrm{Li}$ et al., 2006). In several insects, C-type or C-type-like ASTs can have both allatostatic and allatotropic properties, depending on the age of the animal (Abdel-Latief et al., 2004; Clark et al., 2008; Griebler et al., 2008; Abdel-Latief and Hoffmann, 2010). In Diptera two AST-C receptors have been characterized for Drosophila using Xenopus oocytes (Kreienkamp et al., 2002) and for Aedes using HEK cells (Mayoral et al., 2010). Only one AST-C receptor was found to be present in Bombyx (Yamanaka et al., 2008) and in Tribolium (Audsley et al., 2012). Activation of the Bombyx AST-C receptor elicits an increase in intracellular cAMP levels (Yamanaka et al., 2008), while the Tribolium receptor was deorphanized in HEK cells, inducing a $\mathrm{Ca}^{2+}$ response (Audsley et al., 2012). In adult fruit flies, both drostar genes are expressed in the optic lobes and the pars intercerebralis, where the AST-C neuropeptide was also found to be present. This suggests a function in the modulation of visual information processing. In the last larval stage, receptor expression was found in the brain and corpora allata (CA) (Kreienkamp et al., 2002). In Aedes significant differences were observed in tissue distribution and expression levels for the two receptor paralogs (Mayoral et al., 2010). In Tribolium the highest transcript levels were noticed in the head and the gut, with variable amounts in the fat body and reproductive organs. 
These transcript levels were also shown to be sex-dependent (Audsley et al., 2012).

The recently discovered AST CC neuropeptide (AST CC) (Veenstra, 2009a) was also identified in Tribolium and showed to be capable of activating the AST-C receptor in a dose-dependent manner (Audsley et al., 2012). A knock out of the Drosophila Ast$C C$ gene is embryonic lethal, suggesting that it is an essential gene (Veenstra, 2009a).

\section{ALLATOTROPIN RECEPTORS (NP_001127714 ORTHOLOGS)}

AT was named after its ability to stimulate $\mathrm{JH}$ biosynthesis in the CA but is also linked to other functions like myostimulation, cardio-acceleration, regulation of photic entrainment, ion exchange regulation, and the up-regulation of the secretion of digestive enzymes (Veenstra et al., 1994; Würden and Homberg, 1995; Lee et al., 1998; Koladich et al., 2002; Petri et al., 2002; Homberg et al., 2003; Hofer and Homberg, 2006; Lwalaba et al., 2010; Sterkel et al., 2010), of which the myotropic role of AT is probably the most ancestral (Elekonich and Horodyski, 2003). ATs are found in several invertebrate EST and genomic databases (for reviews, see: Clynen and Schoofs, 2009; Weaver and Audsley, 2009) and they all have a TARGF/Y motif at the C-terminus. In Manduca and Bombyx, also AT-like (ATL) neuropeptides were found, which arise by alternative splicing of the AT gene (Horodyski et al., 2001; Nagata et al., 2012a). In 2008, the AT receptor (ATR) was characterized in B. mori (Yamanaka et al., 2008). Remarkable, this receptor was mainly localized in the Short neuropeptide F (sNPF)-producing cells in the CC, but not in the $\mathrm{JH}$ producing $\mathrm{CA}$. It was suggested that AT regulates the production and/or release of sNPFs from the CC and that these sNPFs are responsible for some of the allatotropic functions assigned to the ATs (Yamanaka et al., 2008). In 2011, the ATRs of $M$. sexta, T. castaneum, and A. aegypti were characterized (Horodyski et al., 2011; Vuerinckx et al., 2011; Nouzova et al., 2012) and show, unlike the ligand, remarkable similarity with the vertebrate orexin receptors (Yamanaka et al., 2008; Vuerinckx et al., 2011). Upon activation by AT or ATLs, Manse-ATR, and TricaATR elevate both intracellular $\mathrm{Ca}^{2+}$ and cAMP concentrations in cellular expression systems (Horodyski et al., 2011; Vuerinckx et al., 2011). Expression of ATs and ATRs in the different insect species is likely to be strongly regulated, since large differences were measured between developmental stages, sexes, feeding conditions, etc. (Elekonich and Horodyski, 2003; Horodyski et al., 2011; Vuerinckx et al., 2011; Nouzova et al., 2012). Possibly additional ATRs may be present in some insect species, since very similar additional receptors have been predicted from Bombyx and Aedes genomes (Yamanaka et al., 2008; Nouzova et al., 2012).

\section{CALCITONIN-LIKE DIURETIC HORMONE RECEPTORS (CG32843/CG17415/CG17043 ORTHOLOGS)}

The first calcitonin-like diuretic hormone (CT/DH), called Dippu-DH $\mathrm{DH}_{31}$ was identified in D. punctata (Furuya et al., 2000). More orthologs were discovered by phylogenetic analysis (Zandawala, 2012). CT/DH stimulates fluid secretion by Malpighian tubules and seems to work via a $\mathrm{Ca}^{2+}$-dependent mechanism in D. punctata (Furuya et al., 2000). In Drosophila, $\mathrm{CT} / \mathrm{DH}$ stimulates fluid secretion by activating the apical membrane V-ATPases via cAMP as second messenger (Coast et al., 2001) and in Anopheles the fluid excretion in Malpighian tubules is also cAMP driven (Coast et al., 2005). In Rhodnius, diuresis by CT/DH seems to be independent of cAMP (Te Brugge et al., 2011). CT/DH is also involved in contractions of the gut and associated glands (Te Brugge et al., 2009) and may play a role in ecdysis (Kim et al., 2006a,b). The Drosophila CT/DH receptor (DH31-R1) is activated by Drome- $\mathrm{DH}_{31}$ and is expressed in the Malpighian tubules. The signaling in HEK293 cells was dependent upon co-expression of the receptor component protein (RCP), which is critical for downstream signaling from the mammalian calcitonin-like receptor (Johnson et al., 2005). One $\mathrm{CT} / \mathrm{DH}$ receptor has been predicted in A. aegypti, A. gambiae, A. mellifera, $N$. vitripennis, and T. castaneum and two CT/DH receptors were found in A. pisum, although it is not yet clear whether both paralogues encode a functional CT/DH receptor.

\section{CAPA RECEPTORS (CG14575 ORTHOLOGS)}

The insect capa neuropeptides, or periviscerokinin peptides, usually possess the C-terminal sequence FPRVamide. The insect capability gene encodes a preprohormone containing two capa neuropeptides (capa-1 and capa-2) and one or more pyrokinin-1 (Kean et al., 2002), but they do not activate each other's receptors (Iversen et al., 2002a; Rosenkilde et al., 2003; Cazzamali et al., 2005). Capa neuropeptides have a diuretic effect on the Malpighian tubules of Drosophila (Pollock et al., 2004), but in $R$. prolixus and other insects they act antidiuretic (Coast and Garside, 2005; Paluzzi and Orchard, 2006). Recently, it was shown that the Aedes capa neuropeptide can induce either diuretic or antidiuretic effects depending on the dose (Ionescu and Donini, 2012). In addition, capa neuropeptides have myotropic effects in a variety of insects (Wegener et al., 2002; Predel and Wegener, 2006). Capa receptors have been characterized in Drosophila and in Anopheles (Iversen et al., 2002a; Park et al., 2002; Olsen et al., 2007; Terhzaz et al., 2012). Both capa-1 and capa-2 elicited a dose-dependent response. The gene encoding the Drosophila capa receptor is highly expressed in larval and adult tubules (Terhzaz et al., 2012).

Capa receptors are found in different mosquito species, although not in A. aegypti. In other holometabolous insects, orthologs are found in representatives of the major orders, including Hymenoptera, Coleoptera, and Lepidoptera. The honey bee genome contains two paralogues, as does the $B$. mori and $M$. sexta genome. Also $N$. vitripennis contains a paralogue (XP_001600587.2), formerly suggested lacking this receptor (Hauser et al., 2006, 2010; Yamanaka et al., 2008). Also in Coleoptera, a capa receptor is found in Tribolium (Hauser et al., 2008).

\section{CCHAMIDE-1 AND -2 RECEPTORS (CG30106/CG14484 AND CG14593 ORTHOLOGS)}

The first CCHamide neuropeptide has only recently been identified in B. mori and it was found to be expressed in the central nervous system and the midgut (Roller et al., 2008). Subsequently, two CCHamide neuropeptides were detected in all insects with a sequenced genome (Hansen et al., 2011). In D. melanogaster, cognate receptors have been identified for both CCHamide 
neuropeptides. CG30106 expressed in $\mathrm{CHO} / \mathrm{G} \alpha_{16}$ cells was activated by CCHamide- 1 at nanomolar concentrations but also responded to high concentrations of CCHamide-2. CG14593 was activated by nanomolar concentrations of CCHamide- 2 as well as by micromolar concentrations of CCHamide-1 (Hansen et al., 2011). Previously, CG30106 had been described as a receptor for myoinhibiting neuropeptides (Johnson et al., 2003b), but as several independent attempts to repeat this result were fruitless, this was likely an erroneous characterization.

\section{CORAZONIN RECEPTORS (CG10698 ORTHOLOGS)}

The first corazonin was isolated and identified from the CC of $P$. americana and was presented as a new cardioaccelerating neuropeptide (Veenstra, 1989). Corazonin is present in most insects (excluding beetles and aphids) (for reviews, see: Gäde et al., 2008; Li et al., 2008; Weaver and Audsley, 2008; Huybrechts et al., 2010) and the most common corazonin sequence among insects is pQTFQYSRGWTNamide (Predel et al., 2007). The role of corazonin, however, is not restricted to cardio-excitatory actions. In locusts, corazonin is involved in cuticular melanization in the gregarious phase (Tawfik et al., 1999; Tanaka et al., 2002), in M. sexta a role in the initiation of ecdysis behavior is noticed (Kim et al., 2004; Žitňan et al., 2007) and it has been suggested that corazonin is involved in sex-dependent stress responses (Zhao et al., 2010) and in the regulation of insulin producing cells in Drosophila ((Kapan et al., 2012); for reviews, see: Veenstra, 2009b; Boerjan et al., 2010b).

The corazonin receptor was first characterized in Drosophila by making use of a bioluminescence assay (Cazzamali et al., 2002), which was confirmed using Xenopus oocytes (Park et al., 2002). Subsequently, the corazonin receptors for M. sexta (Kim et al., 2004), A. gambiae (Belmont et al., 2006) and B. mori (Shi et al., 2011) were characterized, and a putative corazonin receptor for Musca domestica, was cloned (Sha et al., 2012). Neither the corazonin neuropeptide nor its receptor could be identified in Tribolium (Hauser et al., 2008) or Acyrthosiphon. In N. vitripennis, despite the presence of a corazonin neuropeptide, so far no corazonin receptor could be predicted (Hauser et al., 2010). The invertebrate corazonin receptors are part of the $\mathrm{GnRH}$ receptor superfamily [see section "Adipokinetic Hormone Receptors (CG11325 Orthologs)"] (Lindemans et al., 2011; Roch et al., 2011). The Drosophila receptor is expressed in all developmental stages (Cazzamali et al., 2002). The Manduca corazonin receptor is present in endocrine Inka cells, the source of preecdysis- and ecdysis-triggering hormones, suggesting a role upstream of ecdysis triggering hormone (ETH) (Kim et al., 2004). In Anopheles, there are pronounced spikes of corazonin receptor expression in 2nd instar larvae and around the transition from pupa to adult (Hillyer et al., 2012). In Musca, a high level of corazonin receptor expression was noticed in the larval salivary glands and a moderate level in the central nervous system. In adults, the receptor was expressed both in the head and body (Sha et al., 2012).

\section{CRF-LIKE DIURETIC HORMONE RECEPTORS (CG8422 AND CG12370 ORTHOLOGS)}

The first corticotropin-releasing factor like diuretic hormone $(\mathrm{CRF} / \mathrm{DH})$ was identified in $M$. sexta as a diuretic peptide (DP) consisting of 41 amino acids that shows sequence similarity to corticotropin releasing factor, urotensin I and sauvagine (Kataoka et al., 1989). A second CRF/DH was also discovered in $M$. sexta (Blackburn et al., 1991). CRF/DHs are also referred to as $\mathrm{DH}_{44}$, after the number of amino acids in the CRF/DH of D. melanogaster (Cabrero et al., 2002). CRF/DH increases fluid excretion in vivo (Kataoka et al., 1989) and in vitro (Kay et al., 1991, 1992; Lehmberg et al., 1991; Clottens et al., 1994) and increases cAMP levels in Malpighian tubules (Lehmberg et al., 1991; Kay et al., 1992; Clottens et al., 1994; Furuya et al., 1995). Besides its diuretic function, $\mathrm{CRF} / \mathrm{DH}$ negatively influences feeding and reproduction (Keeley et al., 1992; Van Wielendaele et al., 2012) and stimulates gut contractions (Te Brugge et al., 2009). The $M$. sexta $\mathrm{CRF} / \mathrm{DH}$ receptor was the first to be cloned and was activated by Manse-DH, making use of cAMP as second messenger (Reagan, 1995). Also the CRF/DH receptor in A. domesticus uses cAMP as secondary messenger (Reagan, 1996). The first $D$. melanogaster CRF/DH receptor (DH44-R1), encoded by CG8422, may couple to multiple second messengers as both cAMP and $\mathrm{Ca}^{2+}$ were stimulated upon binding of Drome-DH to the receptor (Johnson et al., 2004). The second D. melanogaster CRF/DH receptor (DH44-R2), encoded by CG12370, is also activated by Drome-DH resulting in an increase of intracellular cAMP and causes specific $\beta$-arrestin translocation to the plasma membrane. DH44-R2 is probably the receptor that modulates DH sensitivity at the level of the microtubules (Hector et al., 2009). A CRF/DH receptor was also cloned in $B$. mori and in A. aegypti (Ha et al., 2000). The Aedes DH-I receptor is by far the most abundant receptor in Malpighian tubules and its transcript levels increase after a blood meal (Jagge and Pietrantonio, 2008). More CRF/DH receptor orthologs were found in T. castaneum and A. pisum, but only one orthologue is found in A. gambiae, A. mellifera, and N. vitripennis up to date. Although the number of receptors seems to differ, $\mathrm{CRF} / \mathrm{DH}$ signaling is likely to be conserved in all major insect orders.

\section{CRUSTACEAN CARDIOACTIVE PEPTIDE RECEPTORS (CG33344/CG6111/CG14547 ORTHOLOGS)}

Crustacean cardioactive peptide (CCAP) was originally identified in the shore crab Carcinus maenas and exhibited an acceleratory effect on semi-isolated heart tissue (Stangier et al., 1987). An identical neuropeptide was subsequently isolated from L. migratoria (Stangier et al., 1989). The structure of CCAP is identical in all examined insects and consists of the cyclic nonapeptide PFCNAFTGCamide. CCAP stimulates heart contractions (Cheung et al., 1992; Furuya et al., 1993; Li et al., 2011a) and contractions of visceral muscles (Stangier et al., 1989; Donini et al., 2001, 2002; Donini and Lange, 2002), and promotes the release of AKH (Veelaert et al., 1997) and digestive enzymes (Sakai et al., 2006). CCAP also plays a role in ecdysis in several insects (Gammie and Truman, 1997; Ewer et al., 1998; Kim et al., 2006a,b; Arakane et al., 2008). Drosophila and Anopheles CCAP receptors have been expressed in $\mathrm{CHO} / \mathrm{G} \alpha_{16}$ cells and are activated by CCAP (Cazzamali et al., 2003; Belmont et al., 2006). In T. castaneum, two genes encode for CCAP receptors (Hauser et al., 2008) and both showed a dose-dependent response to CCAP (Li et al., 2011a). Functional analysis using RNAi revealed that only 
TcCCAPR-2 is essential for cardioacceleratory activity (Li et al., 2011a). CCAP receptor orthologs have been found in A. mellifera (Hauser et al., 2006), A. aegypti, A. pisum, B. mori, and N. vitripennis and thus the CCAP receptor seems to be conserved in many insect orders.

\section{ECDYSIS TRIGGERING HORMONE RECEPTORS (CG5911 ORTHOLOGS)}

To be able to grow and undergo metamorphosis, insects need to shed their exoskeleton, the process known as ecdysis (Truman, 1996). This process is initiated and regulated by the ETH (for a review, see: Žitňan et al., 2007). The eth gene encodes for two active neuropeptides named pre-ETH and ETH in moths and ETH1 and ETH2 in other insects. The ETHs have a common $\mathrm{PRX}_{1}$-amide $\left(\mathrm{X}_{1}\right.$ is $\mathrm{I}, \mathrm{V}, \mathrm{L}$, or $\left.\mathrm{M}\right)$ sequence at the C-terminus (Park et al., 2002). In Drosophila, Manduca, and Bombyx, the two ETHs differ in length. In Drosophila and Manduca the short form only can elicit a part of the ecdysis behaviors, whereas the long one can elicit whole ecdysis (Žitňan et al., 1999; Park et al., 2002). In Bombyx and Aedes, both neuropeptides seemed to be equally potent (Žitňan et al., 2002; Dai and Adams, 2009). In Apis, Nasonia, and Acyrthosiphon only one form is found, that in Apis is shown to be sufficient to elicit ecdysis (Žitňan et al., 1999; Park et al., 2002). These neuropeptides are released in the bloodstream and activate the ETH receptors (ETHRs) situated in the central nervous system. The ethr gene encodes for two splice variants of the receptor, ETRH-A and ETRH-B (Iversen et al., 2002b; Park et al., 2002; Dai and Adams, 2009; Roller et al., 2010), and the first ETHRs were identified in Drosophila (Iversen et al., 2002b; Park et al., 2002). The two forms are expressed in different central neurons (Kim et al., 2006a,b). ETHR-A is expressed in inhibitory and/or excitatory neuropeptide producing neurons, releasing the neuropeptides in response to ETH to regulate ecdysis (Kim et al., 2006a,b). In B. mori ETHR-B is highly expressed in the CA, pointing to a possible allatoregulatory function (Yamanaka et al., 2008). In Drosophila, Manduca, and Aedes activation of both receptors expressed in $\mathrm{CHO}$ cells could increase intracellular $\mathrm{Ca}^{2+}$ levels (Iversen et al., 2002b; Park et al., 2002; Kim et al., 2006a,b; Dai and Adams, 2009). In Bombyx, ETHR-B was expressed in HEK293 cells and was shown to be able to increase intracellular cAMP levels (Yamanaka et al., 2008). In Tribolium, the function of the ETRHs was confirmed through RNAi experiments (Arakane et al., 2008). ETRHs were also found in several holo- and hemimetabolous insects (Riehle et al., 2002; Žitňan et al., 2003; Clynen et al., 2006; Roller et al., 2010).

\section{FMRFAMIDE RECEPTORS (CG2114 ORTHOLOGS)}

The family of (N-terminally extended) FMRFamides is named after the tetrapeptide FMRFamide that was identified in the sunray venus clam Macrocallista nimbosa (Price and Greenberg, 1977), but not all extended FMRFamides retain the exact Cterminal motif. The first extended FMRFamide in insects was cloned and characterized in D. melanogaster (Nambu et al., 1988; Schneider and Taghert, 1988). More extended FMRFamides were detected by mass spectrometric analysis in various major insect orders (Verleyen et al., 2004a; Neupert and Predel, 2005; Li et al., 2008; Ons et al., 2009; Rahman et al., 2009; Huybrechts et al., 2010; Audsley et al., 2011; Zoephel et al., 2012). FMRFamides modulate heart and gut contractions in insects (Banner and Osborne, 1989; Robb and Evans, 1990; Duttlinger et al., 2002). The FMRFamide neurons become active at the early stages of pre-ecdysis in D. melanogaster, suggesting a role in the ecdysis process (Kim et al., 2006b). The Drosophila FMRFamide receptor is the only deorphanized insect FMRFamide receptor so far and was found to be activated by six of the seven endogenous D. melanogaster extended FMRFamides (Cazzamali and Grimmelikhuijzen, 2002; Meeusen et al., 2002). Orthologous FMRFamide receptors are found in A. gambiae (Duttlinger et al., 2003), A. mellifera, N. vitripennis, T. castaneum, A. pisum, and B. mori but have not been characterized up to date. FMRFamide receptors are conserved throughout insects, but our knowledge about these receptors is very limited.

\section{INOTOCIN RECEPTOR (NP_001078830 ORTHOLOGS)}

This neuropeptide was first discovered in the 1980s in L. migratoria and showed similarity to the oxytocin/vasopressin peptide family in Mammalia. The antiparallel dimer of the neuropeptide was described to have diuretic properties (Proux et al., 1987). Although the neuropeptide could not be identified in most insect species with sequenced genomes, it was recently found in T. castaneum and $N$. vitripennis. The mature neuropeptide shows C-terminal amidation. The T. castaneum inotocin receptor was characterized in $\mathrm{CHO} / \mathrm{G} \alpha_{16}$ cells displaying strong activation in the nanomolar range. For both the neuropeptide precursor and its receptor transcript levels have been reported throughout development of T. castaneum, but in larvae and the head of adult beetles high levels were detected (Aikins et al., 2008; Stafflinger et al., 2008). Inotocin was shown to act indirectly as a diuretic factor on Tenebrio molitor Malpighian tubules in the presence of central nervous system and CC-CA (Aikins et al., 2008).

\section{KININ (MYOKININ) RECEPTORS (CG10626 ORTHOLOGS)}

Insect kinins are small neuropeptides that function as myotropic, neuromodulatory, and diuretic hormones in the insect Malphigian tubules (Hayes et al., 1989; Terhzaz et al., 1999; Coast and Garside, 2005). These neuropeptides, which are characterized by the C-terminal sequence $\mathrm{FX}_{1} \mathrm{X}_{2}$ WGamide (where $\mathrm{X}_{1}$ is $\mathrm{F}, \mathrm{H}, \mathrm{N}, \mathrm{S}$ or $\mathrm{Y}$ and $\mathrm{X}_{2}$ is $\mathrm{A}, \mathrm{P}$, or $\mathrm{S}$ ), were first isolated from Leucophea maderae (Holman et al., 1987; Hayes et al., 1989). The Drosophila kinin receptor was deorphanized in S2 cells using a bioluminescence assay (Radford et al., 2002). Antibodies raised against the receptor identified sites of myokinin action like stellate cells of the Malphigian tubules, two triplets of cells in the pars intercerebralis of the adult central nervous sytem and additional cells in the larval nervous system. Western blots and reverse transcription-PCR confirmed these locations, but also identified expression in male and female gonads. These tissues also displayed elevated $\mathrm{Ca}^{2+}$ in response to myokinin, demonstrating novel roles for these neuropeptides (Radford et al., 2002). In A. aegypti the myokinin receptor was shown to be critical for in vivo fluid excretion post blood feeding (Kersch and Pietrantonio, 2011). In Drosophila the receptor was shown to be involved in appetite, chemosensory responses, and metabolism (Al-Anzi et al., 2010; de Haro et al., 2010; Cognigni et al., 2011; López-Arias et al., 2011). Receptor orthologs are also 
present in A. mellifera (Hauser et al., 2006), A. gambiae, Culex quinquefasciatus, $A$. pisum, P. humanus, and $B$. mori, but seem to be absent in $N$. vitripennis and T. castaneum.

\section{LEUCINE-RICH REPEATS CONTAINING GPCRs (LGRs)}

These receptors, which belong to the rhodopsin-like GPCRs, can be considered "the odd ones out" within this receptor family as they display ectodomains that are much larger than is generally the case for rhodopsin-like GPCRs. Based on the structure of the ectodomain and the hinge region which links the ectodomain to the serpentine domain, three major types can be identified within the LGR family (Hsu et al., 2000; Van Hiel et al., 2012).

\section{Type A LGRs (CG7665 orthologs)}

Type A LGRs typically have 7-9 leucine-rich repeats (LRRs) in their ectodomain. Although little data are available on these receptors in insects, they are thought to be of significant importance as they are homologous to the three vertebrate receptors for the glycoprotein hormones (follicle stimulating hormone, thyroid stimulating hormone, luteinizing hormone, and choriogonadotropin). In contrast to the situation in vertebrates, invertebrate genomes encode only one type A LGR and the receptor is conserved in most sequenced insect genomes, but seems to be lost in Hymenoptera (Hauser et al., 2006, 2010; Fan et al., 2010). Another exception is the T. castaneum genome which encodes two type A LGRs (Hauser et al., 2008; Van Hiel et al., 2012).

LGR1 from D. melanogaster is activated by a heterodimer formed by GPA2 and GPB5 (Sudo et al., 2005) which are produced in neuroendocrine cells of the ventral nervous system (Sellami et al., 2011). As is the case for the vertebrate glycoprotein hormones, both of these subunits are cystine knot proteins with complex three dimensional structures (Vitt et al., 2001). Based on transcript studies, $d L g r 1$ gene expression has been detected throughout all developmental stages of the fruit fly (Hauser et al., 1997; Graveley et al., 2011). In wandering larvae and adults, high transcript abundance has been reported for the hindgut and the salivary glands (Chintapalli et al., 2007).

\section{Type B LGRs (CG8930 orthologs)}

LGRs from type B feature 16-18 LRRs, about twice the number found in the other two types (Van Hiel et al., 2012). In vertebrates, three type B LGRs can be identified, whereas in insect genomes only one type B has been found. The D. melanogaster member of the type B LGRs, LGR2 ( $r k$ ) was cloned in 2000 (Eriksen et al., 2000) and was activated by bursicon (Luo et al., 2005; Mendive et al., 2005). Analogous to the known ligands of the LGR type A receptors, this hormone is a heterodimer of cystine knot glycoproteins. The bursicon hormone itself had already been described in the 1960s (Fraenkel et al., 1966), but it took until 2004 before its sequence was unraveled (Dewey et al., 2004; Honegger et al., 2004). Bursicon was found to induce the hardening and darkening of the cuticle of newly eclosed adult flies as well as the expansion of the wings (Luo et al., 2005; Mendive et al., 2005). More recently, bursicon has been shown to be responsible for the maturation of the wing, driving the epithelial-mesenchymal transition of the wing epithelial cells (Natzle et al., 2008), but the authors reported that apoptosis associated with wing maturation was not bursicon-regulated in contrast to previous results (Kimura et al., 2004). With regard to wing expansion, it has been proposed that the bursicon secreting neurons in the abdominal ganglion are responsible for neurohemal release, whereas the bursiconpositive neurons in the subesophageal ganglion would orchestrate wing expansion behavior (Peabody et al., 2008). Also, there are indications that bursicon is released preceding the initiation of larval ecdysis and that it is responsible for tanning the pupal case (Loveall and Deitcher, 2010). Additionally, recent data indicate that homodimers of the bursicon $\alpha$ - and $\beta$-subunits induced innate immunity genes in the fruit fly (An et al., 2012).

In addition to D. melanogaster, LGR2 homologues have been identified in representatives of most insect orders including in $A$. mellifera, T. castaneum, and A. pisum (Hauser et al., 2006, 2008, 2010; Van Hiel et al., 2012). Interestingly, in A. mellifera a single gene was found to encode bursicon. This protein features two cystine knot domains similar to the dimer of two cystine-knot proteins as is the case in the fruit fly and the silk moth (Mendive et al., 2005).

\section{Type C LGRs (CG31096/CG6857 and CG34411/CG4187 orthologs)}

In contrast to the vertebrate type C LGRs which are activated by members of the insulin-relaxin peptide family, in insects these receptors are largely uncharacterized. In D. melanogaster, two members of the type C LGRs can be identified, dLGR3 and dLGR4. In contrast, in A. mellifera and T. castaneum, only one receptor has been found which is, respectively, most closely related to dLGR3 and dLGR4 (Hauser et al., 2008). The ligands of these receptors are still unknown.

\section{MYOSUPPRESSIN RECEPTORS (CG8985 AND CG43745/CG13803 ORTHOLOGS)}

Myosuppressins have a conserved C-terminal FLRFamide. The first myosuppressin was isolated from $L$. maderae (Holman et al., 1986). Myosuppressins inhibit gut contractions and regulate heart contractions (Holman et al., 1986; Lange and Orchard, 1998; Wasielewski and Skonieczna, 2008; Maestro et al., 2011). They also contribute to the regulation of digestive processes by controlling the release of several digestive enzymes in the alimentary canal (Harshini et al., 2002; Hill and Orchard, 2005). Furthermore, myosuppressins inhibit food uptake and thus seem to classify as anorexic factors (Matthews et al., 2008; Vilaplana et al., 2008; Down et al., 2011; Nagata et al., 2011). The first putative myosuppressin receptor was characterized in L. migratoria. Cold competition binding studies and kinetic binding assays with a radiolabeled ligand were used to calculate the dissociation constant of the receptor (Kwok and Orchard, 2002). D. melanogaster possesses two myosuppressin receptors, DMSR-1 (CG8985) and DMSR-2 (CG43745/CG13803), and were activated by $D$. melanogaster myosuppressin in a dose-dependent manner. Another myosuppressin receptor was characterized in A. gambiae (Schöller et al., 2005). Additional myosuppressin receptors have been annotated in A. aegypti, A. mellifera, N. vitripennis, T. castaneum, A. pisum, and B. mori. DMSR-2 is expressed in the head and the body and possibly regulates the actions of myosuppressin on visceral muscles. DMSR-1 is only expressed in the head (Egerod et al., 2003a). Myosuppressin receptors are not 
evolutionary related to FMRFamide receptors and both represent two separately evolved signaling systems, despite the resemblance of their ligands (Schöller et al., 2005).

\section{NEUROPEPTIDE F RECEPTORS (CG1147 ORTHOLOGS)}

Invertebrate neuropeptide F (NPF) peptides are structural homologues of the vertebrate NPY family. The Drosophila NPF neuropeptide was the first full length member of the NPY/NPF family identified in insects (Brown et al., 1999). The insect NPF neuropeptides are characterized by the consensus sequence $\mathrm{x}_{\mathrm{n}} \mathrm{PxRx}_{\mathrm{n}} \mathrm{YLx}_{2} \mathrm{Lx}_{2} \mathrm{YYx}_{4}$ RPRFamide (Nässel and Wegener, 2011). NPF is involved in various processes in Drosophila like foraging, feeding, alcohol sensitivity, stress, aggression, reproduction, learning, and locomotion (Shen and Cai, 2001; Wu et al., 2003, 2005a,b; Wen et al., 2005; Lee et al., 2006; Dierick and Greenspan, 2007; Lingo et al., 2007; Chen et al., 2008; Krashes et al., 2009; Xu et al., 2010; Hermann et al., 2012; Shohat-Ophir et al., 2012, for a review, see: Nässel and Wegener, 2011). In several other insects NPF is also (predicted to be) involved in feeding behavior (Zhu et al., 1998; Stanek et al., 2002; Garczynski et al., 2005; Gonzalez and Orchard, 2008, 2009; Nuss et al., 2008, 2010; Ament et al., 2011; Huang et al., 2011b). NPF has also an effect on cardiac activity in the blowfly Protophormia terraenovae (Setzu et al., 2012). The Drosophila NPF receptor was characterized by means of a radioreceptor approach. The signaling pathway probably acts via Gi and adenylate cyclase as determined by NPF-induced inhibition of forskolin-stimulated cAMP production (Garczynski et al., 2002). The NPF receptor was also characterized in Anopheles (Garczynski et al., 2005) and has been predicted in several other insects like Bombyx and Tribolium (Hauser et al., 2008; Yamanaka et al., 2008; Fan et al., 2010). The proposed Nasonia NPF receptor (Hauser et al., 2010) is more likely to be a short NPF receptor; consequently there is probably no NPF receptor present in Nasonia. Expression of the Drome-NPF receptor was observed in cells of the midgut and numerous neurons in the brain and ventral nerve cord of the third instar larva (Garczynski et al., 2002). The NPF receptor was also located in the adult brain (Wen et al., 2005; Krashes et al., 2009). The Anoga-NPF receptor was detected in all life stages except for eggs (Garczynski et al., 2005).

\section{PIGMENT DISPERSING FACTOR RECEPTORS (CG13758 ORTHOLOGS)}

The first pigment dispersing factor (PDF) neuropeptide in insects was characterized in Romalea microptera (Rao et al., 1987). The best know function of PDF is its role in the circadian clock as a network coordinator, output factor and regulator of its plasticity similar to the vertebrate vasoactive intestinal peptide (VIP). Further processes that where associated with PDF are activity, reproduction, arousal, and geotaxis (for a review, see: Meelkop et al., 2011). Recently, also a role for PDF in the control of visceral physiology in Drosophila was described, thereby extending the similarities between fly PDF and VIP in mammals (Talsma et al., 2012). In 2005, three research groups simultaneously identified the PDF receptor in Drosophila. Mertens et al. (2005) found the receptor to be specifically responsive to PDF and to couple with Gs, leading to an elevated cAMP concentration upon receptor activation. Mutants showed an aberrant behavioral rhythmicity and a severe negative geotaxis. In a large-scale temperature preference behavior screen in Drosophila, Hyun et al. (2005) identified a mutant that preferred colder temperatures during the night and named it han (Korean for cold). Han seems to be a mutant of a P element controlling the CG13758 gene. But mutations in the latter gene did not cause temperature preference difference. Instead it shows arrhythmic circadian behavior in constant darkness as seen in $p d f$ null mutants. PDF specifically binds to S2 cells expressing HAN and thereby elevates the cAMP level. The third research group also identified a mutant with the same disrupted circadian behavior as $p f d$ mutants and named it groom-of-PDF (gop) (Lear et al., 2005). Later studies showed, however, that only the advanced evening activity is common with the $p d f$ mutants. $p d f r$ mutants, in contrast to $p d f$ mutants, did have a morning peak (Im and Taghert, 2010). There are several indications that $p d f r$ is regulated at steady-state level by the clock gene period (Lear et al., 2005; Mertens et al., 2005). Localization studies showed PDFR expression in the brain and visual system in close correspondence to PDF expression. PDFR expression shows also similarities to the clock pacemaker network of neurons. Furthermore expression is found dispersed in the anterior and posterior surfaces of the central brain and subesophageal ganglion (Shafer et al., 2008; Im and Taghert, 2010). In embryos no expression was noticed (Hyun et al., 2005). Drosophila is the only insect where the PDFR has been deorphanized so far. However, homologous sequences are found in many insects like several Drosophila species, A. gambiae, A. mellifera, N. vitripennis, B. mori, and T. castaneum.

\section{PROCTOLIN RECEPTORS (CG6986 ORTHOLOGS)}

Proctolin or RYLPT is a myo- and neurostimulatory neuropeptide of which the appearance seems to be restricted to arthropods (Starratt and Brown, 1975; Nässel, 2002). It stimulates or potentiates muscle contraction, is cardio-acceleratory and acts as a neurohormone (Orchard et al., 1989; Lange, 2002; Clark et al., 2006; Lange and Orchard, 2006; Nässel and Winther, 2010). The Drosophila gene for the proctolin receptor was identified and cloned (Egerod et al., 2003b; Johnson et al., 2003a,b; Taylor et al., 2004; Orchard et al., 2011). When the receptor was stably expressed in $\mathrm{CHO} / \mathrm{G} \alpha_{16}$ cells, a dose-dependent response was measured for proctolin (Egerod et al., 2003b). In competitionbased studies, the proctolin receptor binds proctolin with high affinity (Johnson et al., 2003a). The proctolin and/or proctolin receptor gene was found in the genomes of only a few insect species, including T. castaneum, T. molitor, P. humanus, and A. pisum (Hauser et al., 2008; Li et al., 2008; Weaver and Audsley, 2008; Huybrechts et al., 2010). No proctolin gene has been identified in genomes of A. aegypti, A. gambiae, A. mellifera, $N$. vitripennis, B. mori, or Acromyrmex echinatior and three other ant species (Hauser et al., 2006, 2010; Roller et al., 2008; Predel et al., 2010; Nygaard et al., 2011), where proctolin and its receptor are now considered absent.

\section{PYROKININ RECEPTORS (CG8784, CG8795 AND CG9918 ORTHOLOGS)}

Pyrokinins are characterized by the C-terminal sequence FXPRLamide (X = S, T, K, A, or G) (Holman et al., 1986; Predel et al., 2001). They are involved in the stimulation of gut motility, the production and release of sex pheromones, diapause, and 
pupariation (Holman et al., 1986; Predel et al., 2001; Nässel, 2002; Altstein, 2004; Verleyen et al., 2004a; Homma et al., 2006). The pyrokinins can be subdivided into two groups, pyrokinin1 (C-terminus WFGPRLamide) and pyrokinin-2 (C-terminus PFKPRLamide) (Cazzamali et al., 2005). The first identified insect pyrokinin receptors were those of $D$. melanogaster, where three pyrokinin receptors occur. CG9918 seems to be specific for pyrokinin-1 and CG8784 and CG8795 for pyrokinin-2 (Park et al., 2002; Rosenkilde et al., 2003; Cazzamali et al., 2005). Two pyrokinin receptors were cloned and pharmacologically characterized in A. gambiae, one being more specific for pyrokinin-1, the other for pyrokinin-2 (Olsen et al., 2007). The pyrokinin-2 receptor orthologue of Helicoverpa zea expressed in Spodoptera frugiperda (Sf) 9 cells also responded to pheromone biosynthesisactivating neuropeptide (PBAN) in the low nanomolar range (Choi et al., 2003).

A. mellifera has two pyrokinin receptor orthologs, but since they both have the same sequence identities $(55-56 \%)$ to the Drosophila genes, it is difficult to classify them as pyrokinin-1 or -2 receptors (Hauser et al., 2006). The T. castaneum genome contains probably three pyrokinin receptors, which are currently classified according to their highest amino acid residue identities (Hauser et al., 2008). Pyrokinin receptors have been found in all insects so far, but it is difficult to classify them as pyrokinin1 or -2 receptors (Jurenka and Nusawardani, 2011). This will remain problematic until in vivo studies using genetics will have solved this issue (Melcher et al., 2006).

\section{RYAMIDE RECEPTORS (CG5811 ORTHOLOGS)}

In 2010, a new class of neuropeptides was discovered from the genome of $N$. vitripennis. These RYamides are characterized by the C-terminal motif FFxxxRYamide (Hauser et al,, 2010). Thereupon, RYamides were identified for all insects with a sequenced genome, except for some ant species (Hauser et al., 2010; Nygaard et al., 2011). Recently, the RYamide receptors for D. melanogaster and T. castaneum were characterized using $\mathrm{CHO} / \mathrm{G}_{16}$ cells. Both Drosophila RYamides were capable of activating the receptor in the nanomolar range. For T. castaneum it was observed that Trica-RYamide-2 is somewhat more potent than Trica-RYamide-1 to activate the receptor (Collin et al., 2011; Ida et al., 2011a). Although the Drosophila receptor was also activated by high concentrations of mammalian NPY and NPYY (Li et al., 1992), a phylogenetic analysis seems to indicate that there is no significant structural relationship between NPY and RYamide receptors (Collin et al., 2011). A first study to unravel the function of the RYamides was performed in Phormia regina. Injections of Drosophila RYamide-1 attenuate the feeding motivation of these flies (Ida et al., 2011a). The receptor is mainly expressed in the hindgut, while it is not, or hardly present in other investigated tissues in Drosophila males and females. This strengthens the hypothesis that the signaling system has a role in digestion, or maybe water reabsorption (Collin et al., 2011; Ida et al., 2011a).

\section{SEX PEPTIDE/MYOINHIBITING PEPTIDE RECEPTOR (CG16752/CG12731 ORTHOLOGS)}

SP induces the post-mating effects that occur in female fruit flies (Kubli and Bopp, 2012). It is produced in the male accessory glands and transferred with the seminal fluid during copulation. It induces egg laying and loss of receptivity for additional mating (Chen et al., 1988), alters the female's sleep pattern (Isaac et al., 2010) and provokes antimicrobial peptide expression (Peng et al., 2005; Domanitskaya et al., 2007). Additionally, the food uptake and preference of females is altered after copulation (Carvalho et al., 2006; Barnes et al., 2007; Kubli, 2010; Ribeiro and Dickson, 2010; Vargas et al., 2010). The SP receptor (SPR) from D. melanogaster has been characterized and homologues of this receptor were identified in various insects with the exception of Hymenoptera (Yapici et al., 2008; Kim et al., 2010). Expression of this receptor is found in the female reproductive organs, especially the spermatheca, and the central nervous system of both males and females in very similar patterns (Yapici et al., 2008; Häsemeyer et al., 2009; Poels et al., 2010).

In addition to SP, the related ductus ejaculatorius peptide (DUP) 99B (Saudan et al., 2002) can activate SPR (Yapici et al., 2008). Although both SP and DUP99B have only been identified in Drosophila species, they can also elicit physiological responses in the lepidopteran Helicoverpa armigera (Fan et al., 1999). As SP and DUB99B so far have only been found in most-not all-Drosophila species, the receptor's evolutionary conservation was a puzzle that was only recently solved. SPR can be activated not only by SP, but also by myoinhibiting peptides (MIPs, also known as B-type ASTs) (Kim et al., 2010; Poels et al., 2010). These neuropeptides show the same evolutionary conservation as SPR and therefore likely correspond to the ancestral ligands of SPR. MIPs display a characteristic $\mathrm{WX}_{6}$ Wamide Cterminal motif and were first purified from L. migratoria (Schoofs et al., 1991), but members of the neuropeptide family were also identified in other species such as Gryllus bimaculatus, $D$. melanogaster, and R. prolixus (Lorenz et al., 1995; Williamson et al., 2001; Lange et al., 2012). MIPs display myoinhibiting activity in visceral muscle preparations in vitro (Schoofs et al., 1991; Blackburn et al., 1995, 2001; Predel et al., 2001). In G. bimaculatus, they inhibit JH biosynthesis (Lorenz et al., 1995), and in D. melanogaster and M. sexta, MIP may silence neurons that are not required during the ecdysis program (Kim et al., 2006a,b). Evidence from B. mori indicates that expression of the MIP receptor is strongly upregulated following a sudden decline of the 20-hydroxyecdysone titer. Therefore, MIP receptor signaling may be involved in the fine-tuning of ecdysteroid titers (Yamanaka et al., 2010).

\section{SHORT NEUROPEPTIDE F RECEPTORS (CG7395/CG18639 ORTHOLOGS)}

sNPF neuropeptides were first identified in A. aegypti and indicated as "Aedes head peptides" (Matsumoto et al., 1989). Nowadays, sNPFs are predicted in all insect with a sequenced genome and they are characterized by the $\mathrm{C}$-terminal consensus sequence xPxLRLRFamide (Nässel and Wegener, 2011). The main functions of sNPF seem to be linked to the regulation of feeding behavior (Lee et al., 2004, 2008, 2009; Chen and Pietrantonio, 2006; Kahsai et al., 2010; Ament et al., 2011; Lu and Pietrantonio, 2011; Nagata et al., 2011, 2012b; Root et al., 2011; Hong et al., 2012; Mikani et al., 2012). Other processes in which sNPF is probably involved in are diapause, learning behavior, ovarian growth stimulation, metabolic stress, cardiac activity, the circadian rhythm, 
and the regulation of hormone production and hormonal release (Schoofs et al., 2001; Huybrechts et al., 2004; Johard et al., 2008; Nässel et al., 2008; Kahsai et al., 2010; Lu and Pietrantonio, 2011; Kapan et al., 2012; Setzu et al., 2012; for a review, see: Nässel and Wegener, 2011). As previously discussed in section "Allatotropin Receptors (NP_001127714 Orthologs)," sNPF peptides may also possess allatotropic activity (Yamanaka et al., 2008). The first sNPF receptor was identified in Drosophila and all four predicted Drosophila sNPF peptides activate the receptor in physiological concentrations (Mertens et al., 2002; Feng et al., 2003). Also in Solenopsis invicta (Chen and Pietrantonio, 2006), A. gambiae (Garczynski et al., 2007), and B. mori (Yamanaka et al., 2008) the sNPF receptor has been deorphaned. When co-expressed in Xenopus oocytes, the Drosophila sNPF receptor activates exogenously expressed inwardly rectifying $\mathrm{K}^{+}$channels (Reale et al., 2004). The sNPF receptor is present in a limited number of neurons in the nervous system of all developmental stages. Throughout development, the receptor is also expressed in peripheral tissues including the gut, Malpighian tubules, fat body, and ovaries as has been shown in various insects (Mertens et al., 2002; Feng et al., 2003; Chen and Pietrantonio, 2006; Garczynski et al., 2007; Yamanaka et al., 2008; Lu and Pietrantonio, 2011; Kahsai et al., 2012; Nagata et al., 2012b).

\section{SIFAMIDE RECEPTORS (CG10823 ORTHOLOGS)}

SIFamides are highly conserved during evolution and have been isolated from various insects (Verleyen et al., 2004b; Audsley and Weaver, 2006). SIFamide is present in four neurons in the insect pars intercerebralis and this specific pattern suggests a neuromodulatory role in combining visual, tactile and olfactory input. Targeted cell ablation and RNAi has revealed that SIFamide modulates sexual behavior in fruit flies (Terhzaz et al., 2007). The Drosophila SIFamide receptor is activated by the SIFamide (Jørgensen et al., 2006). The identification of well-conserved SIFamide receptor orthologs in all insects with a sequenced genome, suggests that SIFamide signaling regulates an essential function in arthropods (Hauser et al., 2006, 2008; Jørgensen et al., 2006; Verleyen et al., 2009).

\section{SULFAKININ AND CHOLECYSTOKININ (CCK)-LIKE RECEPTORS (CG32540/CG6894/CG6881 AND CG42301/CG6857 ORTHOLOGS)}

Sulfakinins (SKs) are the insect homologues of the vertebrate cholecystokinin (CCK) and gastrin neuropeptides (Nachman et al., 1986a,b; Staljanssens et al., 2011). They are named after the sulfated tyrosyl residue in their active core sequence YGHMRFamide that is usually required for biological activity. The first insect SKs were isolated from L. maderae and stimulated hindgut contractions (Nachman et al., 1986a,b). Peptidomic techniques elucidated SK peptides in all major insect orders (Verleyen et al., 2004a; Li et al., 2008; Ons et al., 2009; Hauser et al., 2010; Huybrechts et al., 2010; Audsley et al., 2011; Zoephel et al., 2012). SK regulates food uptake and works as a satiety factor that inhibits feeding in several insect species (Wei et al., 2000; Maestro et al., 2001; Downer et al., 2007; Meyering-Vos and Müller, 2007). Drosulfakinins are coreleased with ILPs and influence food choice in D. Melanogaster (Söderberg et al., 2012). It stimulates hindgut contractions (Nachman et al., 1986a,b; Marciniak et al., 2011), but inhibits contractions of the heart, oviduct and ejaculatory duct (Marciniak et al., 2011). Only one insect SK receptor, the D. melanogaster SK receptor 1 (Drome-SKR1) has been deorphanized so far. It is activated by $\left[\mathrm{Leu}^{7}\right]$-Drome-SK-1 at nanomolar concentrations. $\left[\mathrm{Leu}^{7}\right]$-Drome-SK-1 was tested instead of the endogenous $\left[\mathrm{Met}^{7}\right]$-Drome-SK-1 for stability reasons. The sulphate residue is essential for high-affinity receptor binding in all tested cellular assays (Kubiak et al., 2002). SK receptors are widespread in insects: T. castaneum and A. gambiae have two SK receptors, while A. aegypti, A. mellifera, and B. mori contain at least one.

Drosophila contains a second, recently characterized, SK receptor, the CCK-like receptor (Chen et al., 2012). As both SK receptors probably arose through a gene duplication and because of the high homology between the two, it is likely that they also display similar ligand specificity (Hewes and Taghert, 2001; Kubiak et al., 2002). Both, CCKLR and DSK are strong positive growth regulators of the $D$. melanogaster larval neuromuscular junction (Chen and Ganetzky, 2012), by signaling via the cAMP-protein kinase A (PKA)-CRE binding protein (CREB) pathway, known for its role in structural synaptic plasticity in learning and memory (Chen and Ganetzky, 2012). A $\beta$-arrestin translocation assay in HEK cells was used to show that sulfated drosulfakinins are the endogenous ligands for CCKLR-17D1. Binding of DSK-1S or DSK-2S to the receptor promotes larval locomotion and evokes stress-induced larval escape behavior (Chen et al., 2012).

\section{TACHYKININ RECEPTORS (CG6515 AND CG7887 ORTHOLOGS)}

Insect tachykinins differ from mammalian tachykinins by their $\mathrm{C}$-terminal consensus sequence, which is $\mathrm{FX}_{1} \mathrm{GX}_{2}$ Ramide, rather than FXGLMamide as in mammals. There are many different tachykinin isoforms in each insect, which are all encoded by a single gene (Siviter et al., 2000). They play various roles in neuronal signaling and gut activity (Vanden Broeck, 2001; Nässel, 2002; Coast and Garside, 2005; Predel et al., 2005; Van Loy et al., 2010). The first insect GPCR capable of sensing tachykininrelated neuropeptides was cloned from Drosophila and is termed Drosophila tachykinin receptor (DTKR and CG7887) (Li et al., 1991). Drosophila tachykinin-related neuropeptides (Drome-TKs) are the endogenous ligands of DTKR and dose-dependently increased intracellular $\mathrm{Ca}^{2+}$ concentrations, as well as cyclic AMP levels, when applied on DTKR-expressing HEK293 or S2 cells (Birse et al., 2006; Poels et al., 2007). DTKR is involved in the regulation of insulin signaling and the olfactory sensory processing in the antennal lobe (Ignell et al., 2009; Birse et al., 2011).

A second tachykinin receptor in Drosophila is the neurokinin receptor (NKD and CG6515) (Monnier et al., 1992). Drome-TK-6 (with an Ala instead of Gly) is the only known fly neuropeptide with clear agonist activity on NKD-expressing cells (Poels et al., 2009), which suggests that NKD is able to discriminate between Ala- and Gly-containing isoforms of tachykinin ligands, a feature that does not apply to DTKR (Van Loy et al., 2010). A similar tachykinin receptor has been cloned from Stomoxys calcitrans (STKR) (Guerrero, 1997). Its endogenous ligand, StocaTK, which contains an Ala-residue instead of the highly conserved Gly-residue, behaves as a partial agonist (Poels et al., 2009; Van Loy et al., 2010). 
A putative tachykinin receptor has been cloned from brain tissue of L. maderae (Johard et al., 2001). One or two tachykinin receptor orthologs have been identified in all insects with a sequenced genome (Hauser et al., 2006, 2008), pointing at an indispensable role of these proteins.

\section{TRISSIN RECEPTOR (CG34381/CG14003 ORTHOLOGS)}

Trissin is a recently identified neuropeptide that contains six Cys residues which form three intramolecular disulfide bridges. Trissin has been shown to activate the D. melanogaster GPCR CG34381 stably expressed in $\mathrm{CHO} / \mathrm{G} \alpha_{16}$ cells at picomolar concentrations. Given the toxic and antimicrobial properties of many Cys containing neuropeptides, one hypothesis is that trissin may have an antimicrobial function. Transcript profiling data for trissin and its receptor on the other hand indicated that transcripts for both were present in the central nervous system of third instar larvae and adults, suggesting that trissin might be a neuropeptide (Ida et al., 2011b). Neuropeptides with high sequence similarity to trissin have been found in several Drosophila species and in three mosquitoes, A. aegypti, A. gambiae, and C. quinquefasciatus as well as in B. mori (Ida et al., 2011b). In A. mellifera, raalin displayed sequence similarity with trissin but this neuropeptide only features 5 Cys residues (Kaplan et al., 2007). Since currently no signal sequence or C-terminal processing sites have been identified for this neuropeptide, its sequence may still be incomplete.

\section{REMAINING ORPHAN DROSOPHILA RECEPTORS}

At least 14 GPCRs predicted to have a neuropeptide as cognate ligand are still orphan and include CG4313, CG12290, CG32547/CG12610, CG13229, CG13995, CG33696/CG16726, CG33639/CG5936, CG30340, and CG13575.

The orphan receptor hector (CG4395) is involved in the regulation of Drosophila male courtship behavior. It is expressed in numerous brain cells, mainly in the mushroom bodies, the central complex and, at lower levels, in a subset of glomeruli in the antennal lobes. However, only those cells that co-express fruitless (fru-one of the two main regulators of male courtship behavior besides doublesex) and hector are critical for male courtship (Li et al., 2011b).

The moody gene (CG4322) encodes two splice variants, Moody- $\alpha$ and Moody- $\beta$ that differ in their long carboxy-terminal domains. Both receptors are coexpressed in glial cells that surround and insulate the nervous system, which is required for the formation and maintenance of the Drosophila blood-brain barrier (Bainton et al., 2005; Schwabe et al., 2005; Hatan et al., 2011). The moody receptors are also involved in drug sensitivity (Bainton et al., 2005; for a review, see: Daneman and Barres, 2005).

The receptor encoded by trapped in endoderm 1 (tre1, CG3171) is a functional analog of the CXCR4 receptor of vertebrates, which is involved in tumor metastasis (Kamps et al., 2010). Tre1 is essential for the transepithelial migration of Drosophila germ cells from the posterior midgut toward the gonads (Kunwar et al., 2003). The receptor probably plays a role in three phases of early migration: polarization of germ cells, dispersal into individual cells, and transepithelial migration (Kunwar et al., 2008). Trel also regulates the relative orientation of cortical polarity in embryonic Drosophila neural stem cells (neuroblasts) (Yoshiura et al., 2012).

\section{METHUSELAH (CG6936) AND METHUSELAH-LIKE RECEPTORS}

The methuselah ( $m$ th) gene encodes a family B GPCR and is involved in stress response and biological ageing in Drosophila (Lin et al., 1998). Also 15 methuselah-like (mthl) relatives were identified in Drosophila, most of them characterized by a unique motif in the extracellular domain consisting of up to ten cysteine residues and several glycosylation sites (West et al., 2001; Patel et al., 2012). Two peptides were identified capable of activating the Mth receptor in a dose-dependent manner. These peptides correspond with the splice variants A and B of the Drosophila gene stunted (sun), which codes for the $\varepsilon$-subunit of mitochondrial ATP synthase (Cvejic et al., 2004; Kidd et al., 2005). The $\mathrm{EC}_{50}$ values for both polypeptides, however, were quite high with $4 \mu \mathrm{M}$ for Sun A and 3.8 $\mu \mathrm{M}$ for Sun B. A second splice variant of the receptor was activated in somewhat lower doses with an $\mathrm{EC}_{50}$ value of $0.6 \mu \mathrm{M}$ for Sun A and Sun B. The stunted gene was also shown to be involved in ageing and oxidative stress (Cvejic et al., 2004). Later on, the Drosophila SP and a non-physiological peptide with a randomly generated sequence, the serendipitous peptide activator of Mth (SPAM), were also identified as agonists of the Mth receptor. The peptides share almost no sequence homology with Sun A and B, indicating the promiscuity of Mth for activation (Ja et al., 2009). However, mth mutants do not affect behaviors controlled by SP, so it is doubtful that activation of the Mth receptor by these ligands is of any biological significance (Ja et al., 2009). An extensive developmental expression and sequence divergence study was performed by Patel et al. (2012). More studies are needed to affirm which are the cognate ligands of the Mth receptor and to unravel the physiological roles of the methuselah-like receptors.

\section{REMAINING ORPHAN NEUROPEPTIDES}

For several neuropeptides, including the ion transport peptides (ITPs), neuroparsins, orcokinins, and amnesiac, the cognate receptor is unknown at the moment. ITPs function as antidiuretic hormones in locusts (Audsley et al., 1992; Phillips et al., 2001). ITPs are found in the genomes of many insect orders including dipterans, lepidopterans, and coleopterans (Dircksen et al., 2008; Begum et al., 2009; Dircksen, 2009).

Neuroparsins are pleiotropic neuropeptides and are inter alia involved in reproduction and serve as molecular markers of the process of phase transition in locusts (Brown et al., 1998; Girardie et al., 1998; Claeys et al., 2005b, 2006; Badisco et al., 2007). It is noteworthy that in the genus Drosophila, the gene coding for the neuroparsins is absent from the melanogaster subgroup of the subgenus Sophophora, although present in other species of the genus (Veenstra, 2010).

Insect orcokinins were first identified in B. germanica and $S$. gregaria (Pascual et al., 2004; Hofer et al., 2005) and were subsequently detected in various other insects, excluding Drosophila and Tribolium (Roller et al., 2008). A study in L. maderae indicates that orcokinins are involved in circadian behavior (Hofer and Homberg, 2006). In B. mori it was demonstrated that orcokinins act as prothoracicotropic factors and as such are involved in 
ecdysteroidogenesis (Yamanaka et al., 2011). Recently, a new family of neuropeptides was discovered in $R$. prolixus, named Orcokinin B, because it arises due to alternative splicing of the orcokinin gene. Orcokinin B expression is observed in several insects, except Drosophila spp. and A. pisum (Sterkel et al., 2012).

The amnesiac ( $a m n$ ) gene, which encodes a putative neuropeptide precursor (Feany and Quinn, 1995; Moore et al., 1998), is important for stabilizing olfactory memory, and is involved in various aspects of other associative and non-associative learning (Quinn et al., 1979; Gong et al., 1998; DeZazzo et al., 1999; Keene et al., 2004, 2006; Yu et al., 2006; Motosaka et al., 2007). Additional studies have indicated that $a m n$ is also involved in ethanol sensitivity, sleep, temperature preference behavior and nociception (Moore et al., 1998; Hong et al., 2008; Liu et al., 2008; Aldrich et al., 2010). The amn gene was found to code for neuropeptides closely related to the vertebrate pituitary adenylate cyclase-activating polypeptide (PACAP) and submammalian glucagon/growth hormone-releasing hormone (GHRH) and were shown to possess phylogenetically conserved functions (Hashimoto et al., 2002).

\section{DISCUSSION AND FUTURE PROSPECTS}

This review clearly shows that during the last two decades a tremendous progress has been made on the field of insect neuropeptide signaling systems. This progress is mostly attributable to the increased availability of insect genomes and the advancing fields of genomics and peptidomics. It became clear that several of these systems are well conserved in all insect species, suggesting that they are indispensable in general insect physiological functions. Other neuropeptides and their receptors were apparantly lost during evolution in several insect species or orders, suggesting that they were otiose, or that their functions were taken over by other ligands. To gain more insight into the evolution of neuropeptide GPCRs across the Insecta, more insect genomes need to be sequenced, which may soon be accomplished due to the i5K project (Robinson et al., 2011). But despite the great progression made in insect endocrinology, the knowledge about the functions of many of the neuropeptides and their receptors involved is still scarce. Furthermore, even in Drosophila, the preeminent insect model organism, various receptors are still orphan and the physiological roles they play are still a mystery. It may be obvious that a lot of work has to be performed before the functions of the different signaling systems will be clearly understood and to unravel how these systems are intertwined with each other. This information is also necessary to get a better view on the evolutionary origin of the peptide-receptor couples and how they changed during evolution among species. It should be emphasized that sequence similarity between different insects does not necessarily implies functional similarity or vice versa. So, it remains a prerequisite to functionally characterize neuropeptide GPCRs in several insect model species. Reverse genetic tools including RNAi, or the application of the fairly new technique of genome editing using engineered zinc finger nucleases (Urnov et al., 2010) are only some of the methods being developed in several insects, which will likely boost GPCR functional research. Nevertheless, cross genome clustering of receptors based on sequence homology may be a good starting point to acquire a better view on their putative functions (Metpally and Sowdhamini, 2005).
The usefulness of research on insect neuropeptide signaling systems goes beyond the world of insects as several mammalian neuropeptides and/or their receptors have orthologs in insects. Well studied examples of such conserved signaling systems are the GnRH (Lindemans et al., 2011; Roch et al., 2011; De Loof et al., 2012), the tachykinin (Pennefather et al., 2004; Van Loy et al., 2010), the NPF/NPY (Nässel and Wegener, 2011), the capapyrokinin/neuromedin (Melcher et al., 2006; Terhzaz et al., 2012), the AST C/somatostatin (Birgül et al., 1999; Veenstra, 2009a), the myoinhibiting peptide/galanin (Blackburn et al., 1995), the PDF/VIP (Vosko et al., 2007; Talsma et al., 2012), the diuretic hormone/corticotropin releasing hormone (Lovejoy et al., 2009; De Loof et al., 2012), the diuretic hormone/calcitonin (Zandawala, 2012), and the SK/CCK (Staljanssens et al., 2011) orthologs, meaning that these signaling systems arose before the divergence of the Proto- and Deuterostomia (more than 700 million years ago). This strengthens the reasons to study insect endocrinology as these studies can help and learn vertebrate endocrinologists more about the current vertebrate receptors (Grimmelikhuijzen and Hauser, 2012a).

It should be clear that the importance of neuropeptides and their receptors in insect physiology can hardly be overestimated. The great variety among the neuropeptides and their receptors between different insect species makes them also potential targets for the development of a new generation of insecticides with high species specificity (Grimmelikhuijzen et al., 2007; Bendena, 2010; Grimmelikhuijzen and Hauser, 2012b). Such insecticides would ideally only be harmful for pest insects like insects acting as vectors for diseases or herbivorous insects detrimental for agriculture, while beneficial insects would be unharmed. The development of such new controlling agents is necessary because of the detrimental effects of the currently used insecticides on the environment and their toxicity to non-target organisms. The increasing resistance of pest insects against the used insecticides is also an expanding problem (Casida and Quistad, 1998; Van Hiel et al., 2010). As such, more and more research is performed on neuropeptides in order to develop synthetic ligands that can disturb the proper functioning of neuropeptide signaling systems, provoking detrimental effects on the insect's fitness. Once again we want to emphasize the importance of elucidating the biochemical pathways and the functions of the neuropeptides in order to be able to design these so called peptidomimetics. Hitherto, no neuropeptide-based insecticides are in use, but a lot of progress is made on a number of interesting neuropeptides (Teal et al., 1999; Gäde and Goldsworthy, 2003; Altstein, 2004; Scherkenbeck and Zdobinsky, 2009; Altstein and Nässel, 2010; Nachman and Pietrantonio, 2010).

\section{ACKNOWLEDGMENTS}

The authors acknowledge the Research Foundation Flanders (FWO-Vlaanderen, Belgium, G.0417.08) and the KU Leuven Research Foundation GOA/11/002. Heleen Verlinden is a postdoctoral research fellow of the FWO-Vlaanderen. Sven Zels is supported by the Flemish government agency for Innovation by Science and Technology (IWT-Vlaanderen, Belgium). Hans Peter Vandersmissen and Kristel Vuerinckx are supported by the KU Leuven. 


\section{REFERENCES}

Abdel-Latief, M., Meyering-Vos, M., and Hoffmann, K. H. (2004). Characterization of a novel peptide with allatotropic activity in the fall armyworm Spodoptera frugiperda. Regul. Pept. 122, 69-78.

Abdel-Latief, M., and Hoffmann, K. H. (2010). Neuropeptide regulators of the juvenile hormone biosynthesis (in vitro) in the beetle, Tenebrio molitor (Coleoptera, Tenebrionidae). Arch. Insect Biochem. Physiol. 74, 135-146.

Adams, M. D., Celniker, S. E., Holt, R. A., Evans, C. A., Gocayne, J. D., Amanatides, P. G., et al. (2000). The genome sequence of Drosophila melanogaster. Science 287, 2185-2195.

Aguilar, R., Maestro, J. L., Vilaplana, L., Pascual, N., Piulachs, M.-D., and Bellés, X. (2003). Allatostatin gene expresión in brain and midgut, and activity of synthetic allatostatins on feeding-related processes in the cockroach Blattella germanica. Regul. Pept. 115, 171-177.

Aikins, M. J., Schooley, D. A., Begum, K., Detheux, M., Beeman, R. W., and Park, Y. (2008). Vasopressinlike peptide and its receptor function in an indirect diuretic signaling pathway in the red flour beetle. Insect Biochem. Mol. Biol. 38, 740-748.

Al-Anzi, B., Armand, E., Nagamei, P., Olszewski, M., Sapin, V., Waters, C., et al. (2010). The leucokinin pathway and its neurons regulate meal size in Drosophila. Curr. Biol. 20, 969-978.

Aldrich, B. T., Kasuya, J., Faron, M., Ishimoto, H., and Kitamoto, T. (2010). The amnesiac gene is involved in the regulation of thermal nociception in Drosophila melanogaster. J. Neurogenet. 24, 33-41.

Altstein, M. (2004). Novel insect control agents based on neuropeptide antagonists: the PK/PBAN family as a case study. J. Mol. Neurosci. 22, 147-157.

Altstein, M., and Nässel, D. R. (2010). Neuropeptide signaling in insects. Adv. Exp. Med. Biol. 692, 155-165.

Ament, S. A., Velarde, R. A., Kolodkin, M. H., Moyse, D., and Robinson, G. E. (2011). Neuropeptide Y-like signalling and nutritionally mediated gene expression and behaviour in the honey bee. Insect Mol. Biol. 20, 335-345.

An, S., Dong, S., Wang, Q., Li, S., Gilbert, L. I., Stanley, D., et al. (2012). Insect neuropeptide bursicon homodimers induce innate immune and stress genes during molting by activating the NF-kappaB transcription factor relish. PLoS ONE 7:e34510. doi: 10.1371/journal.pone.0034510

Arakane, Y., Li, B., Muthukrishnan, S., Beeman, R. W., Kramer, K. J., and Park, Y. (2008). Functional analysis of four neuropeptides, $\mathrm{EH}$, ETH, CCAP and bursicon, and their receptors in adult ecdysis behavior of the red flour beetle, Tribolium castaneum. Mech. Dev. 125, 984-995.

Arrese, E. L., and Soulages, J. L. (2010). Insect fat body: energy, metabolism, and regulation. Annu. Rev. Entomol. 55, 207-225.

Attardo, G. M., Benoit, J. B., Michalkova, V., Yang, G., Roller, L., Bohova, J., et al. (2012). Analysis of lipolysis underlying lactation in the tsetse fly, Glossina morsitans. Insect Biochem. Mol. Biol. 42, 360-370.

Audsley, N., Matthews, H. J., Down, R. E., and Weaver, R. J. (2011). Neuropeptides associated with the central nervous system of the cabbage root fly, Delia radicum (L). Peptides 32, 434-440.

Audsley, N., Matthews, H. J., Price, N. R., and Weaver, R. J. (2008). Allatoregulatory peptides in Lepidoptera, structures, distribution and functions. J. Insect Physiol. 54, 969-980.

Audsley, N., McIntosh, C., and Phillips, J. E. (1992). Isolation of a neuropeptide from locust corpus cardiacum which influences ileal transport. J. Exp. Biol. 173, 261-274.

Audsley, N., and Weaver, R. J. (2006). Analysis of peptides in the brain and corpora cardiaca-corpora allata of the honey bee, Apis mellifera using MALDI-TOF mass spectrometry. Peptides 27, 512-520.

Audsley, N., Weaver, R. J., and Edwards, J. P. (1998). Enzyme linked immunosorbent assay for Manduca sexta allatostatin (Mas$\mathrm{AS})$, isolation and measurement of Mas-AS immunoreactive peptide in Lacanobia oleracea. Insect Biochem. Mol. Biol. 28, 775-784.

Audsley, N., and Weaver, R. J. (2009). Neuropeptides associated with the regulation of feeding in insects. Gen. Comp. Endocrinol. 162, 93-104.

Audsley, N., Vandersmissen, H. P., Weaver, R., Dani, P., Matthews, J., Down, R., et al. (2012). Characterisation and tissue distribution of the PISCF allatostatin receptor in the red flour beetle, Tribolium castaneum. Insect Biochem. Mol. Biol. doi: 10.1016/ j.ibmb.2012.09.007. [Epub ahead of print].
Auerswald, L., Birgül, N., Gäde, G. Kreienkamp, H. J., and Richter, D. (2001). Structural, functional, and evolutionary characterization of novel members of the allatostatin receptor family from insects. Biochem. Biophys. Res. Commun. 282, 904-909.

Badisco, L., Claeys, I., Van Loy, T., Van Hiel, M. B., Franssens, V., Simonet, G., et al. (2007). Neuroparsins, a family of conserved arthropod neuropeptides. Gen. Comp. Endocrinol. 153, 64-71.

Baggerman, G., Boonen, K., Verleyen, P., De Loof, A., and Schoofs, L. (2005b). Peptidomic analysis of the larval Drosophila melanogaster central nervous system by twodimensional capillary liquid chromatography quadrupole time-offlight mass spectrometry. J. Mass Spectrom. 40, 250-260.

Baggerman, G., Huybrechts, J., Clynen, E., Hens, K., Harthoorn, L., Van Der Horst, D., et al. (2002). New insights in Adipokinetic Hormone $(\mathrm{AKH})$ precursor processing in Locusta migratoria obtained by capillary liquid chromatography-tandem mass spectrometry. Peptides 23, 635-644.

Baggerman, G., Liu, F., Wets, G., and Schoofs, L. (2005a). Bioinformatic analysis of peptide precursor proteins. Ann. N.Y. Acad. Sci. 1040, 59-65.

Bainton, R. J., Tsai, L. T., Schwabe, T., DeSalvo, M., Gaul, U., and Heberlein, U. (2005). moody encodes two GPCRs that regulate cocaine behaviors and blood-brain barrier permeability in Drosophila. Cell 123, 145-156.

Banner, S. E., and Osborne, R. H. (1989). Modulation of 5HT and proctolin receptors by FMRFamide in the foregut of the locust Schistocerca gregaria. J. Insect Physiol. 35, 887-892.

Barnes, A. I., Boone, J. M., Partridge, L., and Chapman, T. (2007). A functioning ovary is not required for sex peptide to reduce receptivity to mating in D. melanogaster. J. Insect Physiol. 53, 343-348.

Beets, I., Lindemans, M., Janssen, T., and Verleyen, P. (2011). Deorphanizing g protein-coupled receptors by a calcium mobilization assay. Methods Mol. Biol. 789, 377-391.

Begum, K., Li, B., Beeman, R. W., and Park, Y. (2009). Functions of ion transport peptide and ion transport peptide-like in the red flour beetle Tribolium castaneum. Insect Biochem. Mol. Biol. 39, 717-725.
Bellés, X. (2010). Beyond Drosophila: RNAi in vivo and functional genomics in insects. Annu. Rev. Entomol. 55, 111-128.

Bellés, X., Maestro, J.-L., Piulachs, M.-D., Johnsen, A. H., Duve, H., and Thorpe, A. (1994). Allatostatic neuropeptides from the cockroach Blattella germanica (L.) (Dictyoptera, Blattellidae) Identification, immunolocalization and activity. Regul. Pept. 53, 237-247.

Belmont, M., Cazzamali, G., Williamson, M., Hauser, F. and Grimmelikhuijzen, C. J. P. (2006). Identification of four evolutionarily related G proteincoupled receptors from the malaria mosquito Anopheles gambiae. Biochem. Biophys. Res. Commun. 344, 160-165.

Bendena, W. G. (2010). Neuropeptide physiology in insects. Adv. Exp. Med. Biol. 692, 166-191.

Bendena, W. G., Campbell, J., Zara, L., Tobe, S. S., and Chin-Sang, I. D. (2012). Select neuropeptides and their G-protein coupled receptors in Caenorhabditis elegans and Drosophila melanogaster. Front. Endocrin. 3:93. doi: 10.3389/fendo.2012.00093

Bender, E., Buist, A., Jurzak, M., Langlois, X., Baggerman, G., Verhasselt, P., et al. (2002). Characterization of an orphan $\mathrm{G}$ protein-coupled receptor localized in the dorsal root ganglia reveals adenine as a signaling molecule. Proc. Natl. Acad. Sci. U.S.A. 99, 8573-8578.

Bharucha, K. N., Tarr, P., and Zipursky, S. L. (2008). A glucagon-like endocrine pathway in Drosophila modulates both lipid and carbohydrate homeostasis. J. Exp. Biol. 211, 3103-3110.

Birgül, N., Weise, C., Kreienkamp, H. J., and Richter, D. (1999). Reverse physiology in Drosophila: identification of a novel allatostatin-like neuropeptide and its cognate receptor structurally related to the mammalian somatostatin/galanin/opioid receptor family. EMBO J. 18, 5892-5900.

Birse, R. T., Johnson, E. C., Taghert, P. H., and Nässel, D. R. (2006). Widely distributed Drosophila G-proteincoupled receptor (CG7887) is activated by endogenous tachykininrelated peptides. J. Neurobiol. 66, 33-46.

Birse, R. T., Söderberg, J. A. E., Luo, J., Winther, Å. M. E., and Nässel, D. R. (2011). Regulation of insulin-producing cells in the adult Drosophila brain via the tachykinin 
peptide receptor DTKR. J. Exp. Biol. 214(Pt 24), 4201-4208.

Blackburn, M. B., Jaffe, H., Kochansky, J., and Raina, A. K. (2001). Identification of four additional myoinhibitory peptides (MIPs) from the ventral nerve cord of Manduca sexta. Arch. Insect Biochem. Physiol. 48, 121-128.

Blackburn, M. B., Kingan, T. G., Bodnar, W., Shabanowitz, J., Hunt, D. F., Kempe, T., et al. (1991). Isolation and identification of a new diuretic peptide from the tobacco hornworm, Manduca sexta. Biochem. Biophys. Res. Commun. 181, 927-932.

Blackburn, M. B., Wagner, R. M., Kochansky, J. P., Harrison, D. J., Thomas-Laemont, P., and Raina, A. K. (1995). The identification of two myoinhibitory peptides, with sequence similarities to the galanins, isolated from the ventral nerve cord of Manduca sexta. Regul. Pept. 57, 213-219.

Bockaert, J., and Pin, J. P. (1999). Molecular tinkering of $\mathrm{G}$ proteincoupled receptors: an evolutionary success. EMBO J. 18, 1723-1729.

Boerjan, B., Cardoen, D., Bogaerts, A., Landuyt, B., Schoofs, L., and Verleyen, P. (2010a). Mass spectrometric profiling of (neuro)-peptides in the worker honeybee, Apis mellifera. Neuropharmacology 58, 248-258.

Boerjan, B., Verleyen, P., Huybrechts, J., Schoofs, L., and De Loof, A. (2010b). In search for a common denominator for the diverse functions of arthropod corazonin: a role in the physiology of stress? Gen. Comp. Endocrinol. 166, 222-233.

Boerjan, B., Cardoen, D., Verdonck, R., Caers, J., and Schoofs, L. (2012). Insect omics research coming of age. Can. J. Zool. 90, 440-455.

Boonen, K., Landuyt, B., Baggerman, G., Husson, S. J., Huybrechts, J., and Schoofs, L. (2008). Peptidomics: the integrated approach of MS, hyphenated techniques and bioinformatics for neuropeptide analysis. J. Sep. Sci. $31,427-445$.

Brody, T., and Cravchik, A. (2000). Drosophila melanogaster $\mathrm{G}$ proteincoupled receptors. J. Cell Biol. 150, F83-F88.

Brogiolo, W., Stocker, H., Ikeya, T., Rintelen, F., Fernandez, R., and Hafen, E. (2001). An evolutionarily conserved function of the Drosophila insulin receptor and insulin-like peptides in growth control. Curr. Biol. 11, 213-221.

Brown, M. R., Crim, J. W., Arata, R. C., Cai, H. N., Chun, C., and Shen, P. (1999). Identification of a Drosophila brain-gut peptide related to the neuropeptide $\mathrm{Y}$ family. Peptides 20, 1035-1042.

Brown, M. R., Graf, R., Swiderek, K. M., Fendley, D., Stracker, T. H., Champagne, D. E., et al. (1998). Identification of a steroidogenic neurohormone in female mosquitoes. J. Biol. Chem. 273, 3967-3971.

Cabrero, P., Radford, J. C., Broderick, K. E., Costes, L., Veenstra, J. A., Spana, E. P., et al. (2002). The Dh gene of Drosophila melanogaster encodes a diuretic peptide that acts through cyclic AMP. J. Exp. Biol. 205, 3799-3807.

Caers, J., Peeters, L., Janssen, T., De Haes, W., Gäde, G., and Schoofs, L. (2012). Structure-activity studies of Drosophila adipokinetic hormone (AKH) by a cellular expression system of dipteran AKH receptors. Gen. Comp. Endocrinol. 177, 332-337.

Carvalho, G. B., Kapahi, P., Anderson, D. J., and Benzer, S. (2006). Allocrine modulation of feeding behavior by the sex peptide of Drosophila. Curr. Biol. 16, 692-696.

Casida, J. E., and Quistad, G. B. (1998). Golden age of insecticide research: past, present, or future? Annu. Rev. Entomol. 43, 1-16.

Cazzamali, G., and Grimmelikhuijzen, C. J. P. (2002). Molecular cloning and functional expression of the first insect FMRFamide receptor. Proc. Natl. Acad. Sci. U.S.A. 99, 12073-12078.

Cazzamali, G., Hauser, F., Kobberup, S., Williamson, M., and Grimmelikhuijzen, C. J. P. (2003). Molecular identification of a Drosophila G protein-coupled receptor specific for crustacean cardioactive peptide. Biochem. Biophys. Res. Commun. 303, 146-152.

Cazzamali, G., Saxild, N., and Grimmelikhuijzen, C. J. P. (2002). Molecular cloning and functional expression of a Drosophila corazonin receptor. Biochem. Biophys. Res. Commun. 298, 31-36.

Cazzamali, G., Torp, M., Hauser, F., Williamson, M., and Grimmelikhuijzen, C. J. P. (2005). The Drosophila gene CG9918 codes for a pyrokinin-1 receptor. Biochem. Biophys. Res. Commun. 335, 14-19.

Chang, J. C., Yang, R. B., Adams, M. E., and Lu, K. H. (2009). Receptor guanylyl cyclases in Inka cells targeted by eclosion hormone. Proc. Natl. Acad. Sci. U.S.A. 106, 13371-13376.

Chen, J., Zhang, Y., and Shen, P. (2008). A protein kinase C activity localized to neuropeptide Y-like neurons mediates ethanol intoxication in Drosophila melanogaster. Neuroscience 156, 42-47.

Chen, M. E., and Pietrantonio, P. V. (2006). The short neuropeptide Flike receptor from the red imported fire ant, Solenopsis invicta Buren (Hymenoptera: Formicidae). Arch. Insect Biochem. Physiol. 61, 195-208.

Chen, P. S., Stumm-Zollinger, E., Aigaki, T., Balmer, J., Bienz, M., and Bohlen, P. (1988). A male accessory gland peptide that regulates reproductive behavior of female $D$. melanogaster. Cell 54, 291-298.

Chen, X., and Ganetzky, B. (2012). A neuropeptide signaling pathway regulates synaptic growth in Drosophila. J. Cell Biol. 196, 529-543.

Chen, X., Peterson, J., Nachman, R. J., and Ganetzky, B. (2012). Drosulfakinin activates CCKLR$17 \mathrm{D} 1$ and promotes larval locomotion and escape response in Drosophila. Fly 6, 1-8.

Cheung, C. C., Loi, P. K., Sylwester, A. W., Lee, T. D., and Tublitz, N. J. (1992). Primary structure of a cardioactive neuropeptide from the tobacco hawkmoth, Manduca sexta. FEBS Lett. 313, 165-168.

Chintapalli, V. R., Wang, J., and Dow, J. A. (2007). Using FlyAtlas to identify better Drosophila melanogaster models of human disease. Nat. Genet. 39, 715-720.

Choi, M. Y., Fuerst, E. J., Rafaeli, A., and Jurenka, R. (2003). Identification of a G protein-coupled receptor for pheromone biosynthesis activating neuropeptide from pheromone glands of the moth Helicoverpa zea. Proc. Natl. Acad. Sci. U.S.A. 100, 9721-9726.

Claeys, I., Poels, J., Simonet, G., Franssens, V., Van Loy, T., Van Hiel, M. B., et al. (2005a). Insect neuropeptide and peptide hormone receptors: current knowledge and future directions. Vitam. Horm. 73 , 217-282.

Claeys, I., Simonet, G., Breugelmans, B., Van Soest, S., Franssens, V., Sas, F., et al. (2005b). Quantitative real-time RT-PCR analysis in desert locusts reveals phase dependent differences in neuroparsin transcript levels. Insect Mol. Biol. 14, 415-422.

Claeys, I., Breugelmans, B., Simonet, G., Van Soest, S., Sas, F., De Loof, A., et al. (2006). Neuroparsin transcripts as molecular markers in the process of desert locust (Schistocerca gregaria) phase transition. Biochem. Biophys. Res. Commun. 341, 599-606.

Clark, L., Lange, A. B., Zhang, J. R., and Tobe, S. S. (2008). The roles of Dippu-allatostatin in the modulation of hormone release in Locusta migratoria. J. Insect Physiol. 54, 949-958.

Clark, L., Zhang, J. R., Tobe, S. S., and Lange, A. B. (2006). Proctolin: a possible releasing factor in the corpus cardiacum/corpus allatum of the locust. Peptides 27, 559-566.

Clottens, F. L., Holman, G. M., Coast, G. M., Totty, N. F., Hayes, T. K., Kay, I., et al. (1994). Isolation and characterization of a diuretic peptide common to the house fly and stable fly. Peptides 15, 971-979.

Clynen, E., Huybrechts, J., Verleyen, P., De Loof, A., and Schoofs, L. (2006). Annotation of novel neuropeptide precursors in the migratory locust based on transcript screening of a public EST database and mass spectrometry. BMC Genomics 7:201. doi: 10.1186/1471-2164-7-201

Clynen, E., and Schoofs, L. (2009). Peptidomic survey of the locust neuroendocrine system. Insect Biochem. Mol. Biol. 39, 491-507.

Clynen, E., Liu, F., Husson, S. J., Landuyt, B., Hayakawa, E., Baggerman, G., et al. (2010b). Bioinformatic approaches to the identification of novel neuropeptide precursors. Methods Mol. Biol. 615, 357-374.

Clynen, E., Reumer, A., Baggerman, G., Mertens, I., and Schoofs, L. (2010a). Neuropeptide biology in Drosophila. Adv. Exp. Med. Biol. 692, 192-210.

Coast, G. M., and Garside, C. S. (2005) Neuropeptide control of fluid balance in insects. Ann. N.Y. Acad. Sci. 1040, 1-8.

Coast, G. M., Garside, C. S., Webster, S. G., Schegg, K. M., and Schooley, D. A. (2005). Mosquito natriuretic peptide identified as a calcitoninlike diuretic hormone in Anopheles gambiae (Giles). J. Exp. Biol. 208, 3281-3291.

Coast, G. M., Webster, S. G., Schegg, K. M., Tobe, S. S., and Schooley, D. A. (2001). The Drosophila melanogaster homologue of an insect calcitonin-like diuretic peptide stimulates V-ATPase activity in fruit fly Malpighian tubules. J. Exp. Biol. 204, 1795-1804.

Cognigni, P., Bailey, A. P., and MiguelAliaga, I. (2011). Enteric neurons and systemic signals couple nutritional and reproductive status with intestinal homeostasis. Cell Metab. $13,92-104$.

Collin, C., Hauser, F., Krogh-Meyer, P., Hansen, K. K., de Gonzalez, V., Williamson, M., et al. (2011). Identification of the Drosophila and Tribolium receptors for the recently 
discovered insect RYamide neuropeptides. Biochem. Biophys. Res. Commun. 412, 578-583.

Cvejic, S., Zhu, Z., Felice, S. J., Berman, Y., and Huang, X.-Y. (2004). The endogenous ligand stunted of the GPCR methuselah extends lifespan in Drosophila. Nat. Cell Biol. 6, 540-546.

Dai, H., Ma, L., Wang, J., Jiang, R., Wang, Z., and Fei, J. (2008). Knockdown of ecdysis-triggering hormone gene with a binary UAS/GAL4 RNA interference system leads to lethal ecdysis deficiency in silkworm. Acta Biochim. Biophys. Sin. (Shanghai) 40, 790-795.

Dai, L., and Adams, M. E. (2009). Ecdysis triggering hormone signaling in the yellow fever mosquito Aedes aegypti. Gen. Comp. Endocrinol. 162, 43-51.

Daneman, R., and Barres, B. A. (2005). The blood-brain barrier-lessons from moody flies. Cell 123, 9-12.

de Haro, M., Al-Ramahi, I., BenitoSipos, J., López-Arias, B., Dorado, B., Veenstra, J. A., et al. (2010). Detailed análisis of leucokininexpressing neurons and their candidate functions in the Drosophila nervous system. Cell Tissue Res. 339, 321-336.

De Loof, A. (2008). Ecdysteroids, juvenile hormone and insect neuropeptides: recent successes and remaining major challenges. Gen. Comp. Endocrinol. 155, 3-13.

De Loof, A., Lindemans, M., Liu, F., De Groef, B., and Schoofs, L. (2012). Endocrine archeology: do insects retain ancestrally inherited counterparts of the vertebrate releasing hormones GnRH, GHRH, TRH, and CRF? Gen. Comp. Endocrinol. 177, 18-27.

Dewey, E. M., McNabb, S. L., Ewer, J., Kuo, G. R., Takanishi, C. L., Truman, J. W., et al. (2004). Identification of the gene encoding bursicon, an insect neuropeptide responsible for cuticle sclerotization and wing spreading. Curr. Biol. 14, 1208-1213.

DeZazzo, J., Xia, S., Christensen, J., Velinzon, K., and Tully, T. (1999). Developmental expression of an $\mathrm{amn}^{+}$transgene rescues the mutant memory defect of amnesiac adults. J. Neurosci. 19, 8740-8746.

Dierick, H. A., and Greenspan, R. J. (2007). Serotonin and neuropeptide F have opposite modulatory effects on fly aggression. Nat. Genet. 39, 678-682.

Dietzl, G., Chen, D., Schnorrer, F., Su, K. C., Barinova, Y., Fellner, M., et al. (2007). A genome-wide transgenic RNAi library for conditional gene inactivation in Drosophila. Nature $448,151-156$

Dircksen, H. (2009). Insect ion transport peptides are derived from alternatively spliced genes and differentially expressed in the central and peripheral nervous system. J. Exp. Biol. 212, 401-412.

Dircksen, H., Tesfai, L. K., Albus, C., and Nassel, D. R. (2008). Ion transport peptide splice forms in central and peripheral neurons throughout postembryogenesis of Drosophila melanogaster. J. Comp. Neurol. 509, 23-41.

Domanitskaya, E. V., Liu, H., Chen, S., and Kubli, E. (2007). The hydroxyproline motif of male sex peptide elicits the innate immune response in Drosophila females. FEBS J. 274, 5659-5668.

Donini, A., Agricola, H., and Lange, A. B. (2001). Crustacean cardioactive peptide is a modulator of oviduct contractions in Locusta migratoria. J. Insect Physiol. 47, 277-285.

Donini, A., and Lange, A. B. (2002). The effects of crustacean cardioactive peptide on locust oviducts are calcium-dependent. Peptides 23 , 683-691.

Donini, A., Ngo, C., and Lange, A. B. (2002). Evidence for crustacean cardioactive peptide-like innervation of the gut in Locusta migratoria. Peptides 23, 1915-1923.

Down, R. E., Matthews, H. J., and Audsley, N. (2011). Oral activity of FMRFamide-related peptides on the pea aphid Acyrthosiphon pisum (Hemiptera: Aphididae) and degradation by enzymes from the aphid gut. Regul. Pept. 171, 11-18.

Downer, K. E., Haselton, A. T., Nachman, R. J., and Stoffolano, J. G. Jr. (2007). Insect satiety: sulfakinin localization and the effect of drosulfakinin on protein and carbohydrate ingestion in the blow fly, Phormia regina (Diptera: Calliphoridae). J. Insect Physiol. 53, 106-112.

Duttlinger, A., Berry, K., and Nichols, R. (2002). The different effects of three Drosophila melanogaster dFMRFamide-containing peptides on crop contractions suggest these structurally related peptides do not play redundant functions in gut. Peptides 23, 1953-1957.

Duttlinger, A., Mispelon, M., and Nichols, R. (2003). The structure of the FMRFamide receptor and activity of the cardioexcitatory neuropeptide are conserved in mosquito. Neuropeptides 37, 120-126.

Egerod, K., Reynisson, E., Hauser, F., Cazzamali, G., Williamson, M., and
Grimmelikhuijzen, C. J. P. (2003a) Molecular cloning and functional expression of the first two specific insect myosuppressin receptors. Proc. Natl. Acad. Sci. U.S.A. 100, 9808-9813.

Egerod, K., Reynisson, E., Hauser, F., Williamson, M., Cazzamali, G., and Grimmelikhuijzen, C. J. P. (2003b). Molecular identification of the first insect proctolin receptor. Biochem. Biophys. Res. Commun. 306, 437-442.

Elekonich, M. M., and Horodyski, F. M. (2003). Insect allatotropins belong to a family of structurally-related myoactive peptides present in several invertebrate phyla. Peptides 24 , 1623-1632.

Eriksen, K. K., Hauser, F., Schiøtt, M., Pedersen, K.-M., Søndergaard, L., and Grimmelikhuijzen, C. J. P. (2000). Molecular cloning, genomic organization, developmental regulation, and a knock-out mutant of a novel leu-rich repeats-containing G protein-coupled receptor (DLGR2) from Drosophila melanogaster. Genome Res. 10, 924-938.

Ewer, J. (2005). Behavioral actions of neuropeptides in invertebrates: insights from Drosophila. Horm. Behav. 48, 418-429.

Ewer, J., Wang, C. M., Klukas, K. A., Mesce, K. A., Truman, J. W., and Fahrbach, S. E. (1998). Programmed cell death of identified peptidergic neurons involved in ecdysis behavior in the Moth, Manduca sexta. J. Neurobiol. 37, 265-280.

Fan, Y., Rafaeli, A., Gileadi, C., Kubli, E., and Applebaum, S. W. (1999) Drosophila melanogaster sex peptide stimulates juvenile hormone synthesis and depresses sex pheromone production in Helicoverpa armigera. J. Insect Physiol. 45, 127-133.

Fan, Y., Sun, P., Wang, Y., He, X., Deng, X., Chen, X., et al. (2010). The $\mathrm{G}$ protein-coupled receptors in the silkworm, Bombyx mori. Insect Biochem. Mol. Biol. 40, 581-591.

Feany, M. B., and Quinn, W. G. (1995). A neuropeptide gene defined by the Drosophila memory mutant amnesiac. Science 268, 869-873.

Feng, G. P., Reale, V., Chatwin, H. M., Kennedy, K., Venard, R., Ericsson, C., et al. (2003). Functional characterization of a neuropeptide F-like receptor from Drosophila melanogaster. Eur. J. Neurosci. 18, 227-238.

Fernandez, R., Tabarini, D., Azpiazu, N., Frasch, M., and Schlessinger, J. (1995). The Drosophila insulin receptor homolog: a gene essential for embryonic development encodes two receptor isoforms with different signaling potential. $E M B O$ J. 14, 3373-3384.

Fire, A., Xu, S., Montgomery, M. K., Kostas, S. A., Driver, S. E., and Mello, C. C. (1998). Potent and specific genetic interference by doublestranded RNA in Caenorhabditis elegans. Nature 391, 806-811.

Fraenkel, G., Hsiao, C., and Seligman, M. (1966). Properties of bursicon: an insect protein hormone that controls cuticular tanning. Science 151, 91-93.

Furuya, K., Liao, S., Reynolds, S. E., Ota, R. B., Hackett, M., and Schooley, D. A. (1993). Isolation and identification of a cardioactive peptide from Tenebrio molitor and Spodoptera eridania. Biol. Chem. Hoppe Seyler 374, 1065-1074.

Furuya, K., Milchak, R. J., Schegg, K. M., Zhang, J., Tobe, S. S., Coast, G. M., et al. (2000). Cockroach diuretic hormones: characterization of a calcitonin-like peptide in insects. Proc. Natl. Acad. Sci. U.S.A. 97, 6469-6474.

Furuya, K., Schegg, K. M., Wang, H., King, D. S., and Schooley, D. A. (1995). Isolation and identification of a diuretic hormone from the mealworm Tenebrio molitor. Proc. Natl. Acad. Sci. U.S.A. 92, 12323-12327.

Gammie, S. C., and Truman, J. W. (1997). Neuropeptide hierarchies and the activation of sequential motor behaviors in the hawkmoth, Manduca sexta. J. Neurosci. 17, 4389-4397.

Garczynski, S. F., Brown, M. R., Shen, P., Murray, T. F., and Crim, J. W. (2002). Characterization of a functional neuropeptide F receptor from Drosophila melanogaster. Peptides 23, 773-780.

Garczynski, S. F., Crim, J. W., and Brown, M. R. (2005) Characterization of neuropeptide $F$ and its receptor from the African malaria mosquito, Anopheles gambiae. Peptides 26, 99-107.

Garczynski, S. F., Crim, J. W., and Brown, M. R. (2007) Characterization and expression of the short neuropeptide $\mathrm{F}$ receptor in the African malaria mosquito, Anopheles gambiae. Peptides 28, 109-118.

Gäde, G., and Auerswald, L. (2003). Mode of action of neuropeptides from the adipokinetic hormone family. Gen. Comp. Endocrinol. 132, 10-20.

Gäde, G., and Goldsworthy, G. (2003). Insect peptide hormones: a selective review of their physiology and 
potential application for pest control. Pest Manag. Sci. 59, 1063-1075.

Gäde, G. (2004). Regulation of intermediary metabolism and water balance of insects by neuropeptides. Annu. Rev. Entomol. 49, 93-113.

Gäde, G. (2009). Peptides of the adipokinetic hormone/red pigment-concentrating hormone family: a new take on biodiversity. Ann. N.Y. Acad. Sci. 1163, 125-136.

Gäde, G., and Marco, H. G. (2012). The adipokinetic hormone (AKH) of one of the most basal orders of Pterygota: structure and function of Ephemeroptera AKH. J. Insect Physiol. 58, 1390-1396.

Gäde, G., Marco, H. G., Simek, P., Audsley, N., Clark, K. D., and Weaver, R. J. (2008). Predicted versus expressed adipokinetic hormones, and other small peptides from the corpus cardiacum-corpus allatum: a case study with beetles and moths. Peptides 29, 1124-1139.

Gether, U. (2000). Uncovering molecular mechanisms involved in activation of $\mathrm{G}$ protein-coupled receptors. Endocr. Rev. 21, 90-113.

Girardie, J., Huet, J. C., tay-Kadiri, Z., Ettaouil, S., Delbecque, J. P., Fournier, B., et al. (1998). Isolation, sequence determination, physical and physiological characterization of the neuroparsins and ovary maturing parsins of Schistocerca gregaria. Insect Biochem. Mol. Biol. 28, 641-650.

Goldsworthy, G., Chandrakant, S., and Opoku-Ware, K. (2003). Adipokinetic hormone enhances nodule formation and phenoloxidase activation in adult locusts injected with bacterial lipopolysaccharide. J. Insect Physiol. 49, 795-803.

Goldsworthy, G., Opoku-Ware, K., and Mullen, L. (2002). Adipokinetic hormone enhances laminarin and bacterial lipopolysaccharideinduced activation of the prophenoloxidase cascade in the African migratory locust, Locusta migratoria. J. Insect Physiol. 48, 601-608.

Gong, Z.-F., Xia, S.-Z., Liu, L., Feng, C.H., and Guo, A.-K. (1998). Operant visual learning and memory in Drosophila mutants dunce, amnesiac and radish. J. Insect Physiol. 44, 1149-1158.

Gonzalez, R., and Orchard, I. (2008). Characterization of neuropeptide Flike immunoreactivity in the bloodfeeding hemipteran, Rhodnius prolixus. Peptides 29, 545-558.

Gonzalez, R., and Orchard, I. (2009). Physiological activity of neuropeptide $f$ on the hindgut of the blood-feeding hemipteran, Rhodnius prolixus. J. Insect Sci. 9, 1-14.

Graf, R., Neuenschwander, S., Brown, M. R., and Ackermann, U. (1997). Insulin-mediated secretion of ecdysteroids from mosquito ovaries and molecular cloning of the insulin receptor homologue from ovaries of bloodfed Aedes aegypti. Insect Mol. Biol. 6, 151-163.

Graveley, B. R., Brooks, A. N., Carlson, J. W., Duff, M. O., Landolin, J. M., Yang, L., et al. (2011). The developmental transcriptome of Drosophila melanogaster. Nature 471, 473-479.

Griebler, M., Westerlund, S. A., Hoffmann, K. H., and MeyeringVos, M. (2008). RNA interference with the allatoregulating neuropeptide genes from the fall armyworm Spodoptera frugiperda and its effects on the JH titer in the hemolymph. J. Insect Physiol. 54, 997-1007.

Grimmelikhuijzen, C. J. P., Cazzamali, G., Williamson, M., and Hauser, F. (2007). The promise of insect genomics. Pest Manag. Sci. 63, 413-416.

Grimmelikhuijzen, C. J. P., and Hauser, F. (2012a). Mini-review: the evolution of neuropeptide signaling. Regul. Pept. 177, S6-S9.

Grimmelikhuijzen, C. J. P., and Hauser, F. (2012b). "Arthropod genomics and pest management targeting GPCRs," in Advanced Technologies for Managing Insect Pests, eds I. Ishaaya, S. R. Palli, and A. R. Horowitz (Heidelberg: Springer Verlag), 165-177.

Grönke, S., Muller, G., Hirsch, J., Fellert, S., Andreou, A., Haase, T., et al. (2007). Dual lipolytic control of body fat storage and mobilization in Drosophila. PLoS Biol. 5:e137. doi: 10.1371/journal.pbio.0050137

Guerrero, F. D. (1997). Transcriptional expression of a putative tachykininlike peptide receptor gene from stable fly. Peptides 18, 1-5.

Ha, S. D., Kataoka, H., Suzuki, A., Kim, B. J., Kim, H. J., Hwang, S. H., et al. (2000). Cloning and sequence analysis of cDNA for diuretic hormone receptor from the Bombyx mori. Mol. Cells 10, 13-17.

Hansen, K. K., Hauser, F., Cazzamali, G., Williamson, M., and Grimmelikhuijzen, C. J. P. (2006). Cloning and characterization of the adipokinetic hormone receptor from the cockroach Periplaneta americana. Biochem. Biophys. Res. Commun. 343, 638-643.

Hansen, K. K., Hauser, F., Williamson, M., Weber, S. B., and Grimmelikhuijzen, C. J. P. (2011). The Drosophila genes
CG14593 and CG30106 code for G-protein-coupled receptors specifically activated by the neuropeptides CCHamide-1 and CCHamide-2. Biochem. Biophys. Res. Commun. 404, 184-189.

Hansen, K. K., Stafflinger, E., Schneider, M., Hauser, F., Cazzamali, G., Williamson, M., et al. (2010). Discovery of a novel insect neuropeptide signaling system closely related to the insect adipokinetic hormone and corazonin hormonal systems. J. Biol. Chem. 285, 10736-10747.

Harshini, S., Nachman, R. J., and Sreekumar, S. (2002). In vitro release of digestive enzymes by FMRF amide related neuropeptides and analogues in the lepidopteran insect Opisina arenosella (Walk.). Peptides 23, 1759-1763.

Häsemeyer, M., Yapici, N., Heberlein, U., and Dickson, B. J. (2009). Sensory neurons in the Drosophila genital tract regulate female reproductive behavior. Neuron 61, 511-518.

Hashimoto, H., Shintani, N., and Baba, A. (2002). Higher brain functions of PACAP and a homologous Drosophila memory gene amnesiac: insights from knockouts and mutants. Biochem. Biophys. Res. Commun. 297, 427-431.

Hatan, M., Shinder, V., Israeli, D. Schnorrer, F., and Volk, T. (2011). The Drosophila blood brain barrier is maintained by GPCR-dependent dynamic actin structures. J. Cell Biol. 192, 307-319.

Hauser, F., Cazzamali, G. Williamson, M., Blenau, W., and Grimmelikhuijzen, C. J. P. (2006). A review of neurohormone GPCRs present in the fruitfly Drosophila melanogaster and the honey bee Apis mellifera. Prog. Neurobiol. 80 1-19.

Hauser, F., Cazzamali, G., Williamson, M., Park, Y., Li, B., Tanaka, Y., et al. (2008). A genome-wide inventory of neurohormone GPCRs in the red flour beetle Tribolium castaneum Front. Neuroendocrinol. 29:3. doi: 10.1016/j.yfrne.2007.10.003

Hauser, F., Neupert, S., Williamson, M., Predel, R., Tanaka, Y., and Grimmelikhuijzen, C. J. P. (2010). Genomics and peptidomics of neuropeptides and protein hormones present in the parasitic wasp Nasonia vitripennis. J. Proteome Res. 9, 5296-5310.

Hauser, F., Nothacker, H. P., and Grimmelikhuijzen, C. J. P. (1997). Molecular cloning, genomic organization, and developmental regulation of a novel receptor from Drosophila melanogaster structurally related to members of the thyroid-stimulating hormone, follicle-stimulating hormone, luteinizing hormone/choriogonadotropin receptor family from mammals. J. Biol. Chem. 272, 1002-1010.

Hauser, F., Søndergaard, L., and Grimmelikhuijzen, C. J. P. (1998). Molecular cloning, genomic organization and developmental regulation of a novel receptor from Drosophila melanogaster structurally related to gonadotropin-releasing hormone receptors for vertebrates. Biochem. Biophys. Res. Commun. 249, 822-828.

Hayes, T. K., Guan, X. C., Johnson, V., Strey, A., and Tobe, S. S. (1994). Structure-activity studies of allatostatin 4 on the inhibition of juvenile hormone biosynthesis by corpora allata: the importance of individual side chains and stereochemistry. Peptides 15, 1165-1171.

Hayes, T. K., Pannabecker, T. L., Hinckley, D. J., Holman, G. M., Nachman, R. J., Petzel, D. H., et al. (1989). Leucokinins, a new family of ion transport stimulators and inhibitors in insect Malpighian tubules. Life Sci. 44, 1259-1266.

Hector, C. E., Bretz, C. A., Zhao, Y., and Johnson, E. C. (2009). Functional differences between two CRF-related diuretic hormone receptors in Drosophila. J. Exp. Biol. 212, 3142-3147.

Hepler, J. R., and Gilman, A. G. (1992). G proteins. Trends Biochem. Sci. 17, 383-387.

Hergarden, A. C., Tayler, T. D., and Anderson, D. J. (2012). AllatostatinA neurons inhibit feeding behavior in adult Drosophila. Proc. Natl. Acad. Sci. U.S.A. 109, 3967-3972.

Hermann, C., Saccon, R., Senthilan, P. R., Domnik, L., Dircksen, H., Yoshii, T., et al. (2012). The circadian clock network in the brain of different Drosophila species. J. Comp. Neurol. doi: 10.1002/cne.23178. [Epub ahead of print].

Herrero, P. (2012). Fruit fly behavior in response to chemosensory signals. Peptides. 38, 228-237.

Hewes, R. S., and Taghert, P. H. (2001). Neuropeptides and neuropeptide receptors in the Drosophila melanogaster genome. Genome Res. $11,1126-1142$

Hill, S. R., and Orchard, I. (2005). In vitro analysis of the digestive enzymes amylase and alphaglucosidase in the midguts of Locusta migratoria $\mathrm{L}$. in response to the myosuppressin 
SchistoFLRFamide. J. Insect Physiol. $51,1-9$.

Hillyer, J. F., Estevez-Lao, T. Y., Funkhouser, L. J., and Aluoch, V. A. (2012). Anopheles gambiae corazonin: gene structure, expression and effect on mosquito heart physiology. Insect Mol. Biol. 21, 343-355.

Ho, I. H. M., and Murrell-Lagnado, R. D. (1999). Molecular mechanism for sodium-dependent activation of $\mathrm{G}$ protein-gated $\mathrm{K}^{+}$channels. J. Physiol. 520(Pt 3), 645-651.

Hofer, S., Dircksen, H., Tollbäck, P., and Homberg, U. (2005). Novel insect orcokinins: characterization and neural distribution in the brains of selected dicondylian insects. J. Comp. Neurol. 490, 57-71.

Hofer, S., and Homberg, U. (2006). Evidence for a role of orcokininrelated peptides in the circadian clock controlling locomotor activity of the cockroach Leucophaea maderae. J. Exp. Biol. 209, 2794-2803.

Hoffmann, K. H., Meyering-Vos, M., and Lorenz, M. W. (1999). Allatostatins and allatotropins: is the regulation of corpora allata activity their primary function? Eur. J. Entomol. 96, 266.

Holman, G. M., Cook, B. J., and Nachman, R. J. (1986). Primary structure and synthesis of two additional neuropeptides from Leucophaea maderae: members of a new family of cephalomyotropins. Comp. Biochem. Physiol. C 84, 271-276.

Holman, G. M., Cook, B. J., and Nachman, R. J. (1987). Isolation, primary structure and synthesis of leucomyosuppressin, an insect neuropeptide that inhibits the spontaneous contractions of the cockroach hindgut. Comp. Biochem. Physiol. B $88,27-30$.

Homberg, U., Reischig, T., and Stengl, M. (2003). Neural organization of the circadian system of the cockroach Leucophaea maderae. Chronobiol. Int. 20, 577-591.

Homma, T., Watanabe, K., Tsurumaru, S., Kataoka, H., Imai, K., Kamba, M., et al. (2006). G protein-coupled receptor for diapause hormone, an inducer of Bombyx embryonic diapause. Biochem. Biophys. Res. Commun. 344, 386-393.

Honegger, H.-W., Dewey, E. M., and Kostron, B. (2004). From bioassays to Drosophila genetics: strategies for characterizing an essential insect neurohormone, bursicon. Acta Biol. Hung. 55, 91-102.

Hong, S.-T., Bang, S., Hyun, S., Kang, J., Jeong, K., Paik, D., et al. (2008).
cAMP signaling in mushroom bodies modulates temperature preference behaviour in Drosophila. Nature 454, 771-775.

Hong, S. H., Lee, K. S., Kwak, S. J., Kim, A. K., Bai, H., Jung, M. S. et al. (2012). Minibrain/Dyrkla regulates food intake through the Sir2-FOXO-sNPF/NPY pathway in Drosophila and mammals. PLoS Genet. 8:e1002857. doi: 10.1371/journal.pgen.1002857

Hook, V., Funkelstein, L., Lu, D., Bark, S., Wegrzyn, J., and Hwang, S. R. (2008). Proteases for processing proneuropeptides into peptide neurotransmitters and hormones. Annu. Rev. Pharmacol. Toxicol. 48, 393-423.

Horn, F., van der Wenden, E. M., Oliveira, L., IJzerman, A. P., and Vriend, G. (2000). Receptors coupling to $G$ proteins: is there a signal behind the sequence? Proteins 41, 448-459.

Horodyski, F. M., Bhatt, S. R., and Lee, K. Y. (2001). Alternative splicing of transcripts expressed by the Manduca sexta allatotropin (Mas-AT) gene is regulated in a tissue-specific manner. Peptides 22, 263-269.

Horodyski, F. M., Verlinden, H., Filkin, N., Vandersmissen, H. P., Fleury, C., Reynolds, S. E., et al. (2011). Isolation and functional characterization of an allatotropin receptor from Manduca sexta. Insect Biochem. Mol. Biol. 41, 804-814.

Hsu, S. Y., Kudo, M., Chen, T., Nakabayashi, K., Bhalla, A., van der Spek, P. J., et al. (2000). The three subfamilies of leucinerich repeat-containing $G$ proteincoupled receptors (LGR): identification of LGR6 and LGR7 and the signaling mechanism for LGR7. Mol. Endocrinol. 14, 1257-1271.

Huang, H., He, X., Deng, X., Li, G., Ying, G., Sun, Y., et al. (2010). Bombyx adipokinetic hormone receptor activates extracellular signal-regulated kinase 1 and 2 via $G$ protein-dependent PKA and PKC but beta-arrestin-independent pathways. Biochemistry 49, 10862-10872.

Huang, J. H., Bellés, X., and Lee, H. J. (2011a). Functional characterization of hypertrehalosemic hormone receptor in relation to hemolymph trehalose and to oxidative stress in the cockroach Blattella germanica. Front. Endocrin. (Lausanne) 2:114 doi: 10.3389/fendo.2011.00114

Huang, Y., Crim, J. W., Nuss, A. B., and Brown, M. R. (2011b). Neuropeptide F and the corn earworm, Helicoverpa zea: a midgut peptide revisited. Peptides 32, 483-492.

Hummon, A. B., Richmond, T. A., Verleyen, P., Baggerman, G., Huybrechts, J., Ewing, M. A., et al. (2006). From the genome to the proteome: uncovering peptides in the Apis brain. Science 314, 647-649.

Huybrechts, J., Bonhomme, J., Minoli, S., Prunier-Leterme, N., Dombrovsky, A., Abdel-Latief, M., et al. (2010). Neuropeptide and neurohormone precursors in the pea aphid, Acyrthosiphon pisum. Insect Mol. Biol. 19(Suppl. 2), 87-95.

Huybrechts, J., De Loof, A., and Schoofs, L. (2004). Diapausing colorado potato beetles are devoid of short neuropeptide F I and II. Biochem. Biophys. Res. Commun. 317, 909-916.

Hyun, S., Lee, Y., Hong, S. T., Bang, S., Paik, D., Kang, J., et al. (2005). Drosophila GPCR han is a receptor for the circadian clock neuropeptide, P. D. F. Neuron 48, 267-278.

Ida, T., Takahashi, T., Tominaga, H., Sato, T., Kume, K., Ozaki, M. et al. (2011a). Identification of the novel bioactive peptides dRYamide1 and dRYamide-2, ligands for a neuropeptide Y-like receptor in Drosophila. Biochem. Biophys. Res. Commun. 410, 872-877.

Ida, T., Takahashi, T., Tominaga, H., Sato, T., Kume, K., YoshizawaKumagaye, K., et al. (2011b). Identification of the endogenous cysteine-rich peptide trissin, a ligand for an orphan $G$ proteincoupled receptor in Drosophila. Biochem. Biophys. Res. Commun. $414,44-48$.

Iga, M., and Smagghe, G. (2011). Relationship between larval-pupal metamorphosis and transcript expression of insulin-like peptide and insulin receptor in Spodoptera littoralis. Peptides 32, 531-538.

Ignell, R., Root, C. M., Birse, R. T., Wang, J. W., Nässel, D. R., and Winther, $\AA$. M. E. (2009). Presynaptic peptidergic modulation of olfactory receptor neurons in Drosophila. Proc. Natl. Acad. Sci. U.S.A. 106, 13070-13075.

Im, S. H., and Taghert, P. H. (2010). PDF receptor expression reveals direct interactions between circadian oscillators in Drosophila. J. Comp. Neurol. 518, 1925-1945.

Ionescu, A., and Donini, A. (2012). AedesCAPA-PVK-1 displays diuretic and dose dependent antidiuretic potential in the larval mosquito Aedes aegypti (Liverpool). J. Insect Physiol. 58, 1299-1306.
Isaac, R. E., Li, C., Leedale, A. E., and Shirras, A. D. (2010). Drosophila male sex peptide inhibits siesta sleep and promotes locomotor activity in the post-mated female. Proc. Biol. Sci. 277, 65-70.

Isaac, R. E., Taylor, C. A., Hamasaka, Y., Nässel, D. R., and Shirras, A. D. (2004). Proctolin in the postgenomic era: new insights and challenges. Invert. Neurosci. 5, 51-64.

Isabel, G., Martin, J. R., Chidami, S., Veenstra, J. A., and Rosay, P. (2005). AKH-producing neuroendocrine cell ablation decreases trehalose and induces behavioral changes in Drosophila. Am. J. Physiol. Regul. Integr. Comp. Physiol. 288, R531-R538.

Iversen, A., Cazzamali, G. Williamson, M., Hauser, F., and Grimmelikhuijzen, C. J. P. (2002a). Molecular cloning and functional expression of a Drosophila receptor for the neuropeptides capa- 1 and -2. Biochem. Biophys. Res. Commun. 299, 628-633.

Iversen, A., Cazzamali, G., Williamson, M., Hauser, F., and Grimmelikhuijzen, C. J. P. (2002b). Molecular identification of the first insect ecdysis triggering hormone receptors. Biochem. Biophys. Res. Commun. 299, 924-931.

Ja, W. W., Carvalho, G. B., Madrigal, M., Roberts, R. W., and Benzer, S (2009). The Drosophila G proteincoupled receptor, methuselah, exhibits a promiscuous response to peptides. Protein Sci. 18, 2203-2208.

Jagge, C. L., and Pietrantonio, P. V. (2008). Diuretic hormone 44 receptor in malpighian tubules of the mosquito Aedes aegypti: evidence for transcriptional regulation paralleling urination. Insect Mol. Biol. 17, 413-426.

Janssen, T., Husson, S. J., Lindemans, M., Mertens, I., Rademakers, S., Ver Donck, K., et al. (2008). Functional characterization of three $\mathrm{G}$ protein-coupled receptors for pigment dispersing factors in Caenorhabditis elegans. J. Biol. Chem. 283, 15241-15249.

Jedlička, P., Steinbauerová, V., Šimek, P., and Zahradníćková, H. (2012). Functional characterization of the adipokinetic hormone in the pea aphid, Acyrthosiphon pisum. Comp. Biochem. Physiol. A 162, 51-58.

Johard, H. A., Muren, J. E., Nichols, R., Larhammar, D. S., and Nässel, D. R. (2001). A putative tachykinin receptor in the cockroach brain: molecular cloning and analysis of expression by means of antisera to portions of the receptor protein. Brain Res. 919, 94-105. 
Johard, H. A., Enell, L. E., Gustafsson, E., Trifilieff, P., Veenstra, J. A., and Nässel, D. R. (2008). Intrinsic neurons of Drosophila mushroom bodies express short neuropeptide F: relations to extrinsic neurons expressing different neurotransmitters. J. Comp. Neurol. 507, 1479-1496.

Johnson, E. C., Garczynski, S. F., Park, D., Crim, J. W., Nässel, D. R., and Taghert, P. H. (2003a). Identification and characterization of a $G$ protein-coupled receptor for the neuropeptide proctolin in Drosophila melanogaster. Proc. Natl. Acad. Sci. U.S.A. 100, 6198-6203.

Johnson, E. C., Bohn, L. M., Barak, L. S., Birse, R. T., Nässel, D. R., Caron, M. G., et al. (2003b). Identification of Drosophila neuropeptide receptors by $G$ protein-coupled receptors-betaarrestin2 interactions. J. Biol. Chem. 278, 52172-52178.

Johnson, E. C., Bohn, L. M., and Taghert, P. H. (2004). Drosophila CG8422 encodes a functional diuretic hormone receptor. J. Exp. Biol. 207, 743-748.

Johnson, E. C., Shafer, O. T., Trigg, J. S., Park, J., Schooley, D. A., Dow, J. A., et al. (2005). A novel diuretic hormone receptor in Drosophila: evidence for conservation of CGRP signaling. J. Exp. Biol. 208, 1239-1246.

Jørgensen, L. M., Hauser, F., Cazzamali, G., Williamson, M., and Grimmelikhuijzen, C. J. P. (2006). Molecular identification of the first SIFamide receptor. Biochem. Biophys. Res. Commun. 340, 696-701.

Jurenka, R., and Nusawardani, T. (2011). The pyrokinin/ pheromone biosynthesis-activating neuropeptide (PBAN) family of peptides and their receptors in Insecta: evolutionary trace indicates potential receptor ligand-binding domains. Insect Mol. Biol. 20, 323-334.

Kahsai, L., Carlsson, M. A., Winther, A. M., and Nässel, D. R. (2012). Distribution of metabotropic receptors of serotonin, dopamine, GABA, glutamate, and short neuropeptide $\mathrm{F}$ in the central complex of Drosophila. Neuroscience 208, 11-26.

Kahsai, L., Kapan, N., Dircksen, H., Winther, A. M., and Nässel, D. R. (2010). Metabolic stress responses in Drosophila are modulated by brain neurosecretory cells that produce multiple neuropeptides. PLoS ONE 5:e11480. doi: 10.1371/ journal.pone.0011480

Kamps, A. R., Pruitt, M. M., Herriges, J. C., and Coffman, C. R. (2010).
An evolutionarily conserved arginine is essential for Tre1 G proteincoupled receptor function during germ cell migration in Drosophila melanogaster. PLoS ONE 5:e11839. doi: 10.1371/journal.pone.0011839

Kapan, N., Lushchak, O. V., Luo, J., and Nässel, D. R. (2012). Identified peptidergic neurons in the Drosophila brain regulate insulin-producing cells, stress responses and metabolism by coexpressed short neuropeptide $\mathrm{F}$ and corazonin. Cell. Mol. Life Sci. 69, 4051-4066.

Kaplan, N., Morpurgo, N., and Linial, M. (2007). Novel families of toxinlike peptides in insects and mammals: a computational approach. J. Mol. Biol. 369, 553-566.

Kataoka, H., Troetschler, R. G., Li, J. P., Kramer, S. J., Carney, R. L., and Schooley, D. A. (1989). Isolation and identification of a diuretic hormone from the tobacco hornworm, Manduca sexta. Proc. Natl. Acad. Sci. U.S.A. 86, 2976-2980.

Kaufmann, C., and Brown, M. R. (2006). Adipokinetic hormones in the African malaria mosquito, Anopheles gambiae: identification and expression of genes for two peptides and a putative receptor. Insect Biochem. Mol. Biol. 36, 466-481.

Kaufmann, C., Merzendorfer, H., and Gäde, G. (2009). The adipokinetic hormone system in Culicinae (Diptera: Culicidae): molecular identification and characterization of two adipokinetic hormone (AKH) precursors from Aedes aegypti and Culex pipiens and two putative AKH receptor variants from A. aegypti. Insect Biochem. Mol. Biol. 39, 770-781.

Kay, I., Coast, G. M., Cusinato, O., Wheeler, C. H., Totty, N. F., and Goldsworthy, G. (1991). Isolation and characterization of a diuretic peptide from Acheta domesticus. Evidence for a family of insect diuretic peptides. Biol. Chem. Hoppe Seyler 372, 505-512.

Kay, I., Patel, M., Coast, G. M., Totty, N. F., Mallet, A. I., and Goldsworthy, G. (1992). Isolation, characterization and biological activity of a CRF-related diuretic peptide from Periplaneta americana L. Regul. Pept. $42,111-122$.

Kean, L., Cazenave, W., Costes, L., Broderick, K. E., Graham, S., Pollock, V. P., et al. (2002). Two nitridergic peptides are encoded by the gene capability in Drosophila melanogaster. Am. J. Physiol. Regul. Integr. Comp. Physiol. 282, R1297-R1307.
Keeley, L. L., Chung, J. S., and Hayes, T. K. (1992). Diuretic and antifeedant actions by Manduca sexta diuretic hormone in lepidopteran larvae. Cell. Mol. Life Sci. 48, 1145-1148.

Keene, A. C., Krashes, M. J., Leung, B., Bernard, J. A., and Waddell, S. (2006). Drosophila dorsal paired medial neurons provide a general mechanism for memory consolidation. Curr. Biol. 16, 1524-1530.

Keene, A. C., Stratmann, M., Keller, A., Perrat, P. N., Vosshall, L. B. and Waddell, S. (2004). Diverse odor-conditioned memories require uniquely timed dorsal paired medial neuron output. Neuron 44, 521-533.

Kennerdell, J. R., and Carthew, R. W. (1998). Use of dsRNA-mediated genetic interference to demonstrate that frizzled and frizzled 2 act in the wingless pathway. Cell 95 , 1017-1026.

Kersch, C. N., and Pietrantonio, P. V. (2011). Mosquito Aedes aegypti (L.) leucokinin receptor is critical for in vivo fluid excretion post blood feeding. FEBS Lett. 585, 3507-3512.

Kidd, T., Abu-Shumays, R., Katzen, A., Sisson, J. C., Jiménez, G., Pinchin, S., et al. (2005). The $\varepsilon$-subunit of mitochondrial ATP synthase is required for normal spindle orientation during the drosophila embryonic divisions. Genetics 170, 697-708.

Kim, Y. J., Bartalska, K., Audsley, N., Yamanaka, N., Yapici, N., Lee, J. Y., et al. (2010). MIPs are ancestral ligands for the sex peptide receptor. Proc. Natl. Acad. Sci. U.S.A. 107, 6520-6525.

Kim, Y. J., Žitňan, D., Cho, K. H., Schooley, D. A., Mizoguchi, A., and Adams, M. E. (2006a). Central peptidergic ensembles associated with organization of an innate behavior. Proc. Natl. Acad. Sci. U.S.A. 103, 14211-14216.

Kim, Y. J., Žitňan, D., Galizia, C. G., Cho, K. H., and Adams, M. E. (2006b). A command chemical triggers an innate behavior by sequential activation of multiple peptidergic ensembles. Curr. Biol. 16 1395-1407.

Kim, Y. J., Spalovska-Valachova, I., Cho, K. H., Zitnanova, I., Park, Y., Adams, M. E., et al. (2004). Corazonin receptor signaling in ecdysis initiation. Proc. Natl. Acad. Sci. U.S.A. 101, 6704-6709.

Kimura, K., Kodama, A., Hayasaka, Y., and Ohta, T. (2004). Activation of the cAMP/PKA signaling pathway is required for post-ecdysial cell death in wing epidermal cells of Drosophila melanogaster. Development 131, 1597-1606.
Kodrík, D. (2008). Adipokinetic hormone functions that are not associated with insect flight. Physiol. Entomol. 33, 171-180.

Kodrík, D., Krishnan, N., and Habustova, O. (2007). Is the titer of adipokinetic peptides in Leptinotarsa decemlineata fed on genetically modified potatoes increased by oxidative stress? Peptides 28, 974-980.

Kofuji, P., Davidson, N., and Lester, H. A. (1995). Evidence that neuronal G-protein-gated inwardly rectifying $\mathrm{K}+$ channels are activated by $\mathrm{G}$ beta gama subunits and function as heteromultimers. Proc. Natl. Acad. Sci. U.S.A. 92, 6542-6546.

Koladich, P. M., Cusson, M., Bendena, W. G., Tobe, S. S., and McNeil, J. N. (2002). Cardioacceleratory effects of Manduca sexta allatotropin in the true armyworm moth, Pseudaletia unipuncta. Peptides 23, 645-651.

Konuma, T., Morooka, N., Nagasawa, H., and Nagata, S. (2012). Knockdown of the adipokinetic hormone receptor increases feeding frequency in the two-spotted cricket Gryllus bimaculatus. Endocrinology 153, 3111-3122.

Kramer, S. J., Toschi, A., Miller, C. A., Kataoka, H., Quistad, G. B., Li, J. P., et al. (1991). Identification of an allatostatin from the tobacco hornworm Manduca sexta. Proc. Natl. Acad. Sci. U.S.A. 88, 9458-9462.

Krashes, M. J., DasGupta, S., Vreede, A., White, B., Armstrong, J. D., and Waddell, S. (2009). A neural circuit mechanism integrating motivational state with memory expression in Drosophila. Cell 139, 416-427.

Kreienkamp, H. J., Larusson, H. J., Witte, I., Roeder, T., Birgül, N., Hönck, H. H., et al. (2002). Functional annotation of two orphan G-protein-coupled receptors, Drostarl and -2, from Drosophila melanogaster and their ligands by reverse pharmacology. J. Biol. Chem. 277, 39937-39943.

Kubiak, T. M., Larsen, M. J., Burton, K. J., Bannow, C. A., Martin, R A., Zantello, M. R., et al. (2002). Cloning and functional expression of the first Drosophila melanogaster sulfakinin receptor DSK-R1. Biochem. Biophys. Res. Commun 291, 313-320.

Kubli, E. (2010). Sexual behavior: dietary food switch induced by sex. Curr. Biol. 20, 474-476.

Kubli, E., and Bopp, D. (2012). Sexual behavior: how sex peptide flips the postmating switch of female flies. Curr. Biol. 22, 520-522.

Kunwar, P. S., Sano, H., Renault, A. D., Barbosa, V., Fuse, N., and 
Lehmann, R. (2008). Tre1 GPCR initiates germ cell transepithelial migration by regulating Drosophila melanogaster E-cadherin. J. Cell Biol. 183, 157-168.

Kunwar, P. S., Starz-Gaiano, M., Bainton, R. J., Heberlein, U., and Lehmann, R. (2003). Tre1, a G protein-coupled receptor, directs transepithelial migration of Drosophila germ cells. PLoS Biol. 1:E80. doi: 10.1371/journal.pbio.0000080

Kwok, R., and Orchard, I. (2002). Characterization of a putative SchistoFLRFamide receptor in the CNS of Locusta migratoria. Peptides $23,765-772$.

Lange, A. B. (2002). A review of the involvement of proctolin as a cotransmitter and local neurohormone in the oviduct of the locust, Locusta migratoria. Peptides 23, 2063-2070.

Lange, A. B., Alim, U., Vandersmissen, H. P., Mizoguchi, A., Vanden Broeck, J., and Orchard, I. (2012). The distribution and physiological effects of the myoinhibiting peptides in the kissing bug, Rhodnius Prolixus. Front Neurosci. 6:98. doi: 10.3389/fnins.2012.00098

Lange, A. B., and Orchard, I. (1998). The effects of SchistoFLRFamide on contractions of locust midgut. Peptides 19, 459-467.

Lange, A. B., and Orchard, I. (2006). "Proctolin in insects," in Handbook of Biologically Active Peptides, ed A. J. Kastin (New York, NY: Academic Press, Elsevier), 177-180.

Larsen, M. J., Burton, K. J., Zantello, M. R., Smith, V. G., Lowery, D. L., and Kubiak, T. M. (2001). Type A allatostatins from Drosophila melanogaster and Diplotera puncata activate two Drosophila allatostatin receptors, DAR-1 and DAR-2, expressed in $\mathrm{CHO}$ cells. Biochem. Biophys. Res. Commun. 286, 895-901.

Lear, B. C., Merrill, C. E., Lin, J. M., Schroeder, A., Zhang, L., and Allada, R. (2005). A G proteincoupled receptor, groom-of-PDF, is required for PDF neuron action in circadian behavior. Neuron 48, 221-227.

Lee, G., and Park, J. H. (2004). Hemolymph sugar homeostasis and starvation-induced hyperactivity affected by genetic manipulations of the adipokinetic hormone-encoding gene in Drosophila melanogaster. Genetics 167, 311-323.

Lee, G. H., Bahn, J. H., and Park, J. H. (2006). Sex- and clock-controlled expression of the neuropeptide $\mathrm{F}$ gene in Drosophila. Proc. Natl. Acad. Sci. U.S.A. 103, 12580-12585.

Lee, K. S., Hong, S. H., Kim, A. K., Ju, S. K., Kwon, O. Y., and Yu, K. (2009). Processed short neuropeptide $\mathrm{F}$ peptides regulate growth through the ERK-insulin pathway in Drosophila melanogaster. FEBS Lett. 583, 2573-2577.

Lee, K. S., Kwon, O. Y., Lee, J. H., Kwon, K., Min, K. J., Jung, S. A., et al. (2008). Drosophila short neuropeptide F signalling regulates growth by ERK-mediated insulin signalling. Nat. Cell Biol. 10, 468-475.

Lee, K. S., You, K. H., Choo, J. K., Han, Y. M., and Yu, K. (2004). Drosophila short neuropeptide $\mathrm{F}$ regulates food intake and body size. J. Biol. Chem. 279, 50781-50789.

Lee, K. Y., Horodyski, F. M., and Chamberlin, M. E. (1998). Inhibition of midgut ion transport by allatotropin (Mas-AT) and Manduca FLRFamides in the tobacco hornworm Manduca sexta. J. Exp. Biol. 201, 3067-3074.

Lehmberg, E., Ota, R. B., Furuya, K., King, D. S., Applebaum, S. W., Ferenz, H. J., et al. (1991). Identification of a diuretic hormone of Locusta migratoria. Biochem. Biophys. Res. Commun. 179, 1036-1041.

Li, B., Beeman, R. W., and Park, Y. (2011a). Functions of duplicated genes encoding CCAP receptors in the red flour beetle, Tribolium castaneum. J. Insect Physiol. 57, 1190-1197.

Li, B., Predel, R., Neupert, S., Hauser, F., Tanaka, Y., Cazzamali, G., et al. (2008). Genomics, transcriptomics, and peptidomics of neuropeptides and protein hormones in the red flour beetle Tribolium castaneum. Genome Res. 18, 113-122.

Li, X. J., Wolfgang, W., Wu, Y. N., North, R. A., and Forte, M. (1991). Cloning, heterologous expression and developmental regulation of a Drosophila receptor for tachykinin-like peptides. EMBO J. 10, 3221-3229.

Li, X. J., Wu, Y. N., North, R. A., and Forte, M. (1992). Cloning, functional expression, and developmental regulation of a neuropeptide-Y receptor from Drosophila melanogaster. J. Biol. Chem. 267, 9-12.

Li, Y., Hernandez-Martinez, S., Fernandez, F., Mayoral, J. G., Topalis, P., Priestap, H., et al. (2006). Biochemical, molecular, and functional characterization of PISCF-allatostatin, a regulator of juvenile hormone biosynthesis in the mosquito Aedes aegypti. J. Biol. Chem. 281, 34048-34055.

Li., Y., Hoxha, V., Lama, C., Dinh, B. H., Vo, C. N., and Dauwalder, B. (2011b). The hector G-protein coupled receptor is required in a subset of fruitless neurons for male courtship behavior. PLOS ONE 6:e28269. doi: 10.1371/journal.pone.0028269

Lin, Y.-J., Seroude, L., and Benzer, S. (1998). Extended life-span and stress resistance in the Drosophila Mutant methuselah. Science 282, 943-946.

Lindemans, M., Janssen, T., Beets, I., Temmerman, L., Meelkop, E., and Schoofs, L. (2011). Gonadotropinreleasing hormone and adipokinetic hormone signaling systems share a common evolutionary origin. Front. Endocrinol. 2:16. doi: 10.3389/fendo.2011.00016

Lingo, P. R., Zhao, Z., and Shen, P. (2007). Co-regulation of coldresistant food acquisition by insulin- and neuropeptide Y-like systems in Drosophila melanogaster. Neuroscience 148, 371-374.

Liu, F., Baggerman, G., D'Hertog, W. Verleyen, P., Schoofs, L., and Wets, G. (2006). In silico identification of new secretory peptide genes in Drosophila melanogaster. Mol. Cell. Proteomics 5, 510-522.

Liu, W., Guo, F., Lu, B., and Guo, A. (2008). amnesiac regulates sleep onset and maintenance in Drosophila melanogaster. Biochem. Biophys. Res. Commun. 372, 798-803.

López-Arias, B., Dorado, B., and Herrero, P. (2011). Blockade of the release of the neuropeptide leucokinin to determine its possible functions in fly behavior: chemoreception assays. Peptides 32, 545-552.

Lorenz, M. W., Kellner, R., and Hoffmann, K. H. (1995). Identification of two allatostatins from the cricket, Gryllus bimaculatus de Geer (Ensifera, Gryllidae): additional members of a family of neuropeptides inhibiting juvenile hormone biosynthesis. Regul. Pept. $57,227-236$.

Lorenz, M. W., Kellner, R., and Hoffmann, K. H. (1999). Allatostatins in Gryllus bimaculatus (Ensifera: Gryllidae): new structures and physiological properties. Eur. J. Entomol. 96, 267-274.

Lorenz, M. W. (2003). Adipokinetic hormone inhibits the formation of energy stores and egg production in the cricket Gryllus bimaculatus. Comp. Biochem. Physiol. B Biochem. Mol. Biol. 136, 197-206.
Lorenz, M. W., and Gäde, G. (2009). Hormonal regulation of energy metabolism in insects as a driving force for performance. Integr. Comp. Biol. 49, 380-392.

Loveall, B. J., and Deitcher, D. L. (2010). The essential role of bursicon during Drosophila development. BMC Dev. Biol. 10:92. doi: 10.1186/ 1471-213X-10-92

Lovejoy, D. A., Rotzinger, S., and Barsyste-Lovejoy, D. (2009). Evolution of complementary peptide systems: teneurin Cterminal-associated peptides and corticotropin-releasing factor superfamilies. Ann. N.Y. Acad. Sci. 1163, 215-220.

Lu, H. L., and Pietrantonio, P. V. (2011). Immunolocalization of the short neuropeptide $\mathrm{F}$ receptor in queen brains and ovaries of the red imported fire ant (Solenopsis invicta Buren). BMC Neurosci. 12:57. doi: 10.1186/1471-2202-12-57

Lungchukiet, P., Donly, B. C., Zhang, J., Tobe, S. S., and Bendena, W. G. (2008). Molecular cloning and characterization of an allatostatin-like receptor in the cockroach Diploptera punctata. Peptides 29, 276-285.

Luo, C. W., Dewey, E. M., Sudo, S., Ewer, J., Hsu, S. Y., Honegger, H. W., et al. (2005). Bursicon, the insect cuticle-hardening hormone, is a heterodimeric cystine knot protein that activates $\mathrm{G}$ proteincoupled receptor LGR2. Proc. Natl. Acad. Sci. U.S.A. 102, 2820-2825.

Lustig, K. D., Conklin, B. R., Herzmark, P., Taussig, R., and Bourne, H. R. (1993). Type II adenylylcyclase integrates coincident signals from Gs, Gi, and Gq. J. Biol. Chem. 268, 13900-13905.

Lwalaba, D., Hoffmann, K. H., and Woodring, J. (2010). Control of the release of digestive enzymes in the larvae of the fall armyworm, Spodoptera frugiperda. Arch. Insect Biochem. Physiol. 73, 14-29.

Maestro, J. L., Aguilar, R., Pascual, N., Valero, M. L., Piulachs, M. D., Andreu, D., et al. (2001). Screening of antifeedant activity in brain extracts led to the identification of sulfakinin as a satiety promoter in the German cockroach. Are arthropod sulfakinins homologous to vertebrate gastrinscholecystokinins? Eur. J. Biochem 268, 5824-5830.

Maestro, J. L., Tobe, S. S., and Bellés, X. (2011). Leucomyosuppressin modulates cardiac rhythm in the cockroach Blattella germanica. J. Insect Physiol. 57, 1677-1681.

Malik, A., Gäde, G., and Lange, A. B. (2012). Sequencing and 
biological effects of an adipokinetic/hypertrehalosemic peptide in the stick insect, Baculum extradentatum. Peptides 34, 51-56.

Marciniak, P., Kuczer, M., and Rosinski, G. (2011). New physiological activities of myosuppressin, sulfakinin and NVP-like peptide in Zophobas atratus beetle. J. Comp. Physiol. B 181, 721-730.

Matsumoto, S., Brown, M. R., Crim, J. W., Vigna, S. R., and Lea, A. O. (1989). Isolation and primary structure ofneuropeptides from the mosquito, Aedes aegypti, immunoreactive to FMRFamide antiserum. Insect Biochem. Mol. Biol. 19, 277-283.

Matthews, H. J., Audsley, N., and Weaver, R. J. (2008). In vitro and in vivo effects of myo-active peptides on larvae of the tomato moth Lacanobia oleracea and the cotton leaf worm Spodoptera littoralis (Lepidoptera; Noctuidae). Arch. Insect Biochem. Physiol. 69, 60-69.

Mayoral, J. G., Nouzova, M., Brockhoff, A., Goodwin, M., HernandezMartinez, S., Richter, D., et al. (2010). Allatostatin-C receptors in mosquitoes. Peptides 31, 442-450.

Meelkop, E., Temmerman, L., Schoofs, L., and Janssen, T. (2011). Signalling through pigment dispersing hormone-like peptides in invertebrates. Prog. Neurobiol. 93, 125-147.

Meeusen, T., Mertens, I., Clynen, E., Baggerman, G., Nichols, R., Nachman, R. J., et al. (2002). Identification in Drosophila melanogaster of the invertebrate G protein-coupled FMRFamide receptor. Proc. Natl. Acad. Sci. U.S.A. 99, 15363-15368.

Meeusen, T., Mertens, I., De Loof, A., and Schoofs, L. (2003). G proteincoupled receptors in invertebrates: a state of the art. Int. Rev. Cytol. 230, 189-261.

Melcher, C., Bader, R., Walther, S., Simakov, O., and Pankratz, M. J. (2006). Neuromedin U and its putative Drosophila homolog hugin. PLoS Biol. 4:e68. doi: 10.1371/ journal.pbio.0040068

Mendive, F. M., Van Loy, T., Claeysen, S., Poels, J., Williamson, M., Hauser, F., et al. (2005). Drosophila molting neurohormone bursicon is a heterodimer and the natural agonist of the orphan receptor DLGR2. FEBS Lett. 579, 2171-2176.

Menschaert, G., Vandekerckhove, T. T., Baggerman, G., Schoofs, L., Luyten, W., and Van Criekinge, W. (2010). Peptidomics coming of age: a review of contributions from a bioinformatics angle. J. Proteome Res. 9, 2051-2061.

Mertens, I., Meeusen, T., Huybrechts, R., De Loof, A., and Schoofs, L. (2002). Characterization of the short neuropeptide $F$ receptor from Drosophila melanogaster. Biochem. Biophys. Res. Commun. 297, 1140-1148.

Mertens, I., Vandingenen, A., Meeusen, T., De Loof, A., and Schoofs, L. (2004). Postgenomic characterization of G-protein-coupled receptors. Pharmacogenomics 5, 657-672.

Mertens, I., Vandingenen, A., Johnson, E. C., Shafer, O. T., Li, W., Trigg, J. S., et al. (2005). PDF receptor signaling in Drosophila contributes to both circadian and geotactic behaviors. Neuron 48, 213-219.

Mertens, I., Husson, S. J., Janssen, T., Lindemans, M., and Schoofs, L. (2007). PACAP and PDF signaling in the regulation of mammalian and insect circadian rhythms. Peptides 28, 1775-1783.

Metpally, R. P. R., and Sowdhamini, R. (2005). Cross genome phylogenetic analysis of human and Drosophila $G$ protein-coupled receptors: application to functional annotation of orphan receptors. BMC Genomics 6:106. doi: 10.1186/1471-2164-6106

Meyering-Vos, M., and Müller, A. (2007). Structure of the sulfakinin cDNA and gene expression from the Mediterranean field cricket Gryllus bimaculatus. Insect Mol. Biol. 16, 445-454.

Mikani, A., Wang, Q. S., and Takeda, M. (2012). Brain-midgut short neuropeptide $F$ mechanism that inhibits digestive activity of the American cockroach, Periplaneta americana upon starvation. Peptides $34,135-144$.

Monnier, D., Colas, J. F., Rosay, P., Hen, R., Borrelli, E., and Maroteaux, L. (1992). NKD, a developmentally regulated tachykinin receptor in Drosophila. J. Biol. Chem. 267, 1298-1302.

Moore, M. S., DeZazzo, J., Luk, A. Y., Tully, T., Singh, C. M., and Heberlein, U. (1998). Ethanol intoxication in Drosophila: genetic and pharmacological evidence for regulation by the cAMP signaling pathway. Cell 93, 997-1007.

Motosaka, K., Koganezawa, M., Narikawa, S., Furuyama, A., Shinozaki, K., Isono, K., et al. (2007). Cyclic AMP-dependent memory mutants are defective in the food choice behavior of Drosophila. J. Comp. Physiol. A Neuroethol. Sens. Neural Behav. Physiol. 193, 279-283.
Nachman, R. J., Holman, G. M., Cook, B. J., Haddon, W. F., and Ling, N. (1986a). LeucosulfakininII, a blocked sulfated insect neuropeptide with homology to cholecystokinin and gastrin. Biochem. Biophys. Res. Commun. 140, 357-364

Nachman, R. J., Holman, G. M., Haddon, W. F., and Ling, N. (1986b). Leucosulfakinin, a sulfated insect neuropeptide with homology to gastrin and cholecystokinin. Science 234, 71-73.

Nachman, R. J., and Pietrantonio, P. V. (2010). Interaction of mimetic analogs of insect kinin neuropeptides with arthropod receptors. $A d v$. Exp. Med. Biol. 692, 27-48.

Nagata, S., Matsumoto, S., Mizoguchi, A., and Nagasawa, H. (2012a). Identification of cDNAs encoding allatotropin and allatotropinlike peptides from the silkworm, Bombyx mori. Peptides 34, 98-105.

Nagata, S., Matsumoto, S., Nakane, T., Ohara, A., Morooka, N., Konuma, T., et al. (2012b). Effects of starvation on brain short neuropeptide F-1, -2 , and -3 levels and short neuropeptide $\mathrm{F}$ receptor expression levels of the silkworm, Bombyx mori. Front. Endocrinol. (Lausanne) 3:3. doi: 10.3389/fendo.2012.00003

Nagata, S., Morooka, N., Matsumoto, S., Kawai, T., and Nagasawa, H. (2011). Effects of neuropeptides on feeding initiation in larvae of the silkworm, Bombyx mori. Gen. Comp. Endocrinol. 172, 90-95.

Nambu, J. R., Murphy-Erdosh, C., Andrews, P. C., Feistner, G. J., and Scheller, R. H. (1988). Isolation and characterization of a Drosophila neuropeptide gene. Neuron 1 , 55-61.

Natzle, J. E., Kiger, J. A. Jr., and Green, M. M. (2008). Bursicon signaling mutations separate the epithelial-mesenchymal transition from programmed cell death during Drosophila melanogaster wing maturation. Genetics 180, 885-893.

Nässel, D. R. (2002). Neuropeptides in the nervous system of Drosophila and other insects: multiple roles as neuromodulators and neurohormones. Prog. Neurobiol. 68, 1-84.

Nässel, D. R., Enell, L. E., Santos, J. G., Wegener, C., and Johard, H. A. (2008). A large population of diverse neurons in the Drosophila central nervous system expresses short neuropeptide F, suggesting multiple distributed peptide functions. BMC Neurosci. 9:90. doi 10.1186/1471-2202-9-90

Nässel, D. R., and Winther, A. M. (2010). Drosophila neuropeptides in regulation of physiology and behavior. Prog. Neurobiol. 92, 42-104.

Nässel, D. R., and Wegener, C. (2011). A comparative review of short and long neuropeptide $\mathrm{F}$ signaling in invertebrates: any similarities to vertebrate neuropeptide $\mathrm{Y}$ signaling? Peptides 32, 1335-1355.

Neupert, S., and Predel, R. (2005). Mass spectrometric analysis of single identified neurons of an insect. Biochem. Biophys. Res. Commun. 327, 640-645

Nouzova, M., Brockhoff, A., Mayoral, J. G., Goodwin, M., Meyerhof, W., and Noriega, F. G. (2012). Functional characterization of an allatotropin receptor expressed in the corpora allata of mosquitoes. Peptides 34, 201-208.

Nuss, A. B., Forschler, B. T., Crim J. W., and Brown, M. R. (2008) Distribution of neuropeptide F-like immunoreactivity in the Eastern Subterranean termite, Reticulitermes flavipes. J. Insect Sci. $8,1-18$.

Nuss, A. B., Forschler, B. T., Crim, J. W., Te Brugge, V., Pohl, J., and Brown, M. R. (2010). Molecular characterization of neuropeptide $\mathrm{F}$ from the eastern subterranean termite Reticulitermes flavipes (Kollar) (Isoptera: Rhinotermitidae) Peptides 31, 419-428.

Nygaard, S., Zhang, G., Schiott, M., Li, C., Wurm, Y., Hu, H., et al. (2011). The genome of the leaf-cutting ant Acromyrmex echinatior suggests key adaptations to advanced social life and fungus farming. Genome Res. 21, 1339-1348.

Offermanns, S., and Simon, M. I. (1995). G alpha 15 and G alpha 16 couple a wide variety of receptors to phospholipase C. J. Biol. Chem. 270, 15175-15180.

Olsen, S. S., Cazzamali, G., Williamson, M., Grimmelikhuijzen, C. J. P., and Hauser, F. (2007). Identification of one capa and two pyrokinin receptors from the malaria mosquito Anopheles gambiae. Biochem. Biophys. Res. Commun. 362, 245-251.

Ons, S., Richter, F., Urlaub, H., and Pomar, R. R. (2009). The neuropeptidome of Rhodnius prolixus brain. Proteomics 9, 788-792.

Orchard, I., Belanger, J. H., and Lange, A. B. (1989). Proctolin: a review with emphasis on insects. J. Neurobiol. 20, 470-496.

Orchard, I., Lee, d. H., da, S. R., and Lange, A. B. (2011). The proctolin gene and biological effects of proctolin in the blood-feeding bug, Rhodnius prolixus. Front. 
Endocrinol. (Lausanne) 2:59. doi: 10.3389/fendo.2011.00059

Overend, G., Cabrero, P., Guo, A. X., Sebastian, S., Cundall, M., Armstrong, H., et al. (2012). The receptor guanylate cyclase Gyc76C and a peptide ligand, NPLP1-VQQ, modulate the innate immune IMD pathway in response to salt stress. Peptides 34, 209-218.

Paluzzi, J. P., and Orchard, I. (2006). Distribution, activity and evidence for the release of an anti-diuretic peptide in the kissing bug Rhodnius prolixus. J. Exp. Biol. 209, 907-915.

Park, Y., Kim, Y. J., and Adams, M. E. (2002). Identification of G proteincoupled receptors for Drosophila PRXamide peptides, CCAP, corazonin, and AKH supports a theory of ligand-receptor coevolution. Proc. Natl. Acad. Sci. U.S.A. 99, 11423-11428.

Pascual, N., Castresana, J., Valero, M. L., Andreu, D., and Bellés, X. (2004). Orcokinins in insects and other invertebrates. Insect Biochem. Mol. Biol. 34, 1141-1146.

Patel, M. V., Hallal, D. A., Jones, J. W., Bronner, D. N., Zein, R., Caravas, J., et al. (2012). Dramatic expansion and developmental expression diversification of the Methuselah gene family during recent Drosophila evolution. J. Exp. Zool. B Mol. Dev. Evol. 318, 368-387.

Peabody, N. C., Diao, F., Luan, H., Wang, H., Dewey, E. M., Honegger, H. W., et al. (2008). Bursicon functions within the Drosophila CNS to modulate wing expansion behavior, hormone secretion, and cell death. J. Neurosci. 28, 14379-14391.

Peng, J., Zipperlen, P., and Kubli, E. (2005). Drosophila sex-peptide stimulates female innate immune system after mating via the Toll and Imd pathways. Curr. Biol. 15, 1690-1694.

Pennefather, J. N., Lecci, A., Candenas, M. L., Patak, E., Pinto, F. M., and Maggi, C. A. (2004). Tachykinins and tachykinin receptors: a growing family. Life Sci. 74, 1445-1463.

Petri, B., Homberg, U., Loesel, R., and Stengl, M. (2002). Evidence for a role of GABA and Massallatotropin in photic entranement of the circadian clock of the cockroach Leucophaea maderae. J. Exp. Biol. 205, 1459-1469.

Phillips, J. E., Meredith, J., Wang, Y., Zhao, Y., and Brock, H. (2001). "Ion transport peptide (ITP): structure, function, evolution," in Perspectives in Comparative Endocrinology: Unity and Diversity, eds H. J. Goos, R. K. Rastogi, H. Vaudry, and R.
Pierantoni (Bologna: Medimond), 745-752.

Poels, J., Birse, R. T., Nachman, R. J., Fichna, J., Janecka, A., Vanden Broeck, J., et al. (2009). Characterization and distribution of NKD, a receptor for Drosophila tachykinin-related peptide 6 . Peptides 30, 545-556.

Poels, J., Van Loy, T., Vandersmissen, H. P., Van Hiel, M. B., Van Soest, S., Nachman, R. J., et al. (2010). Myoinhibiting peptides are the ancestral ligands of the promiscuous Drosophila sex peptide receptor. Cell. Mol. Life Sci. 67, 3511-3522.

Poels, J., Verlinden, H., Fichna, J., Van Loy, T., Franssens, V., Studzian, K., et al. (2007). Functional comparison of two evolutionary conserved insect neurokinin-like receptors. Peptides 28, 103-108.

Pollock, V. P., McGettigan, J., Cabrero, P., Maudlin, I. M., Dow, J. A., and Davies, S. A. (2004). Conservation of capa peptide-induced nitric oxide signalling in Diptera. J. Exp. Biol. 207, 4135-4145.

Prasher, D. C., McCann, R. O., Longiaru, M., and Cormier, M. J. (1987). Sequence comparisons of complementary DNAs encoding aequorin isotypes. Biochemistry 26, 1326-1332.

Pratt, G. E., Farnsworth, D. E., Fok, K. F., Siegel, N. R., McCormack, A. L., Shabanowitz, J., et al. (1991). Identity of a second type of allatostatin from cockroach brains: an octadecapeptide amide with a tyrosine-rich address sequence. Proc. Natl. Acad. Sci. U.S.A. 88, 2412-2416.

Pratt, G. E., Farnsworth, D. E., Siegel, N. R., Fok, K. F., and Feyereisen, R. (1989). Identification of an allatostatin from adult Diploptera punctata. Biochem. Biophys. Res. Commun. 163, 1243-1247.

Predel, R., Nachman, R. J., and Gäde, G. (2001). Myostimulatory neuropeptides in cockroaches: structures, distribution, pharmacological activities, and mimetic analogs. J. Insect Physiol. 47, 311-324.

Predel, R., Neupert, S., Roth, S., Derst, C., and Nässel, D. R. (2005). Tachykinin-related peptide precursors in two cockroach species. FEBS J. 272, 3365-3375

Predel, R., Neupert, S., Russell, W. K., Scheibner, O., and Nachman, R. J. (2007). Corazonin in insects. Peptides 28, 3-10.

Predel, R., Neupert, S., Garczynski, S. F., Crim, J. W., Brown, M. R., Russell, W. K., et al. (2010). Neuropeptidomics of the mosquito
Aedes aegypti. J. Proteome Res. 9, 2006-2015.

Predel, R., Wegener, C., Russell, W. K., Tichy, S. E., Russell, D. H., and Nachman, R. J. (2004). Peptidomics of CNS-associated neurohemal systems of adult Drosophila melanogaster: a mass spectrometric survey of peptides from individual flies. J. Comp. Neurol. 474, 379-392.

Predel, R., and Wegener, C. (2006). Biology of the CAPA peptides in insects. Cell. Mol. Life Sci. 63 , 2477-2490.

Price, D. A., and Greenberg, M. J. (1977). Purification and characterization of a cardioexcitatory neuropeptide from the central ganglia of a bivalve mollusc. Prep. Biochem. 7, 261-281.

Proux, J. P., Miller, C. A., Li, J. P., Carney, R. L., Girardie, A., Delaage, M., et al. (1987). Identification of an arginine vasopressin-like diuretic hormone from Locusta migratoria. Biochem. Biophys. Res. Commun. 149, 180-186.

Quinn, W. G., Sziber, P. P., and Booker, R. (1979). The Drosophila memory mutant amnesiac. Nature 277 212-214.

Radford, J. C., Davies, S. A., and Dow, J. A. (2002). Systematic Gprotein-coupled receptor analysis in Drosophila melanogaster identifies a leucokinin receptor with novel roles. J. Biol. Chem. 277, 38810-38817.

Rahman, M. M., Fromm, B., Neupert, S., Kreusch, S., and Predel, R. (2009). Extended FMRFamides in dipteran insects: conservative expression in the neuroendocrine system is accompanied by rapid sequence evolution. Gen. Comp. Endocrinol. 162, 52-58.

Rao, K. R., Mohrherr, C. J., Riehm, J. P., Zahnow, C. A., Norton, S., Johnson, L., et al. (1987). Primary structure of an analog of crustacean pigment-dispersing hormone from the lubber grasshopper Romalea microptera. J. Biol. Chem. 262, 2672-2675.

Reagan, J. D. (1994). Expression cloning of an insect diuretic hormone receptor. A member of the calcitonin/secretin receptor family. J. Biol. Chem. 269, 9-12.

Reagan, J. D. (1995). Functional expression of a diuretic hormone receptor in baculovirus-infected insect cells: evidence suggesting that the $\mathrm{N}$-terminal region of diuretic hormone is associated with receptor activation. Insect Biochem. Mol. Biol. $25,535-539$.

Reagan, J. D. (1996). Molecular cloning and function expression of a diuretic hormone receptor from the house cricket, Acheta domesticus. Insect Biochem. Mol. Biol. 26, 1-6.

Reale, V., Chatwin, H. M., and Evans, P. D. (2004). The activation of G-protein gated inwardly rectifying $\mathrm{K}+$ channels by a cloned Drosophila melanogaster neuropeptide F-like receptor. Eur. J. Neurosci. 19, 570-576.

Reumer, A., Van Loy, T., Clynen, E., and Schoofs, L. (2008). How functional genomics and genetics complements insect endocrinology. Gen. Comp. Endocrinol. 155, 22-30.

Rewitz, K. F., Yamanaka, N., Gilbert, L. I., and O'Connor, M. B. (2009). The insect neuropeptide PTTH activates receptor tyrosine kinase torso to initiate metamorphosis. Science 326, 1403-1405.

Rholam, M., and Fahy, C. (2009). Processing of peptide and hormone precursors at the dibasic cleavage sites. Cell. Mol. Life Sci. 66, 2075-2091.

Ribeiro, C., and Dickson, B. J. (2010). Sex peptide receptor and neuronal TOR/S6K signaling modulate nutrient balancing in Drosophila. Curr. Biol. 20, 1000-1005.

Riehle, M. A., Garczynski, S. F., Crim, J. W., Hill, C. A., and Brown, M. R. (2002). Neuropeptides and peptide hormones in Anopheles gambiae. Science 298, 172-175.

Robb, S., and Evans, P. D. (1990). FMRFamide-like peptides in the locust: distribution, partial characterization and bioactivity. J. Exp. Biol. 149, 335-360.

Robinson, G. E., Hackett, K. J., PurcellMiramontes, M., Brown, S. J., Evans, J. D., Goldsmith, M. R., et al. (2011). Creating a buzz about insect genomes. Science 331, 1386.

Roch, G. J., Busby, E. R., and Sherwood, N. M. (2011). Evolution of GnRH: diving deeper. Gen. Comp. Endocrinol. 171, 1-16.

Roller, L., Yamanaka, N., Watanabe, K., Daubnerova, I., Žitňan, D., Kataoka, H., et al. (2008). The unique evolution of neuropeptide genes in the silkworm Bombyx mori. Insect Biochem. Mol. Biol. 38, 1147-1157.

Roller, L., Žitňanová, I., Dai, L., Šimo, L., Park, Y., Satake, H., et al. (2010). Ecdysis triggering hormone signaling in arthropods. Peptides 31 , 429-441.

Root, C. M., Ko, K. I., Jafari, A., and Wang, J. W. (2011). Presynaptic facilitation by neuropeptide signaling mediates odor-driven food search. Cell 145, 133-144.

Rosenkilde, C., Cazzamali, G., Williamson, M., Hauser, F., Søndergaard, L., DeLotto, R., 
et al. (2003). Molecular cloning, functional expression, and gene silencing of two Drosophila receptors for the Drosophila neuropeptide pyrokinin-2. Biochem. Biophys. Res. Commun. 309, 485-494.

Sakai, T., Satake, H., and Takeda, M. (2006). Nutrient-induced alphaamylase and protease activity is regulated by crustacean cardioactive peptide (CCAP) in the cockroach midgut. Peptides 27, 2157-2164.

Saudan, P., Hauck, K., Soller, M., Choffat, Y., Ottiger, M., Sporri, M., et al. (2002). Ductus ejaculatorius peptide 99B (DUP99B), a novel Drosophila melanogaster sexpeptide pheromone. Eur. J. Biochem. 269, 989-997.

Scherkenbeck, J., and Zdobinsky, T. (2009). Insect neuropeptides: structures, chemical modifications and potential for insect control. Bioorg. Med. Chem. 17, 4071-4084.

Schinko, J. B., Weber, M., Viktorinova, I., Kiupakis, A., Averof, M., Klingler, M., et al. (2010). Functionality of the GAL4/UAS system in Tribolium requires the use of endogenous core promoters. BMC Dev. Biol. 10:53. doi: 10.1186/1471-213X-10-53

Schneider, L. E., and Taghert, P. H. (1988). Isolation and characterization of a Drosophila gene that encodes multiple neuropeptides related to Phe-Met-Arg-Phe-NH2 (FMRFamide). Proc. Natl. Acad. Sci. U.S.A. 85, 1993-1997.

Schöller, S., Belmont, M., Cazzamali, G., Hauser, F., Williamson, M., and Grimmelikhuijzen, C. J. P. (2005). Molecular identification of a myosuppressin receptor from the malaria mosquito Anopheles gambiae. Biochem. Biophys. Res. Commun. 327, 29-34.

Schoofs, L., and Baggerman, G. (2003). Peptidomics in Drosophila melanogaster. Brief. Funct. Genomic. Proteomic. 2, 114-120.

Schoofs, L., Clynen, E., Cerstiaens, A., Baggerman, G., Wei, Z., Vercammen, T., et al. (2001). Newly discovered functions for some myotropic neuropeptides in locusts. Peptides 22, 219-227.

Schoofs, L., Holman, G. M., Hayes, T. K., Nachman, R. J., and De Loof, A. (1991). Isolation, primary structure, and synthesis of locustapyrokinin - a myotropic peptide of Locusta migratoria. Gen. Comp. Endocrinol. 81, 97-104.

Schwabe, T., Bainton, R. J., Fetter, R. D., Heberlein, U., and Gaul, U. (2005). GPCR signaling is required for blood-brain barrier formation in Drosophila. Cell 123, 133-144.
Secher, T., Lenz, C., Cazzamali, G., Sorensen, G., Williamson, M., Hansen, G. N., et al. (2001). Molecular cloning of a functional allatostatin gut/brain receptor and an allatostatin preprohormone from the silkworm Bombyx mori. J. Biol. Chem. 276, 47052-47060.

Sellami, A., Agricola, H., and Veenstra, J. A. (2011). Neuroendocrine cells in Drosophila melanogaster producing GPA2/GPB5, a hormone with homology to LH, FSH and TSH. Gen. Comp. Endocrinol. 170, 582-588.

Setzu, M., Biolchini, M., Lilliu, A., Manca, M., Muroni, P., Poddighe, S., et al. (2012). Neuropeptide F peptides act through unique signaling pathways to affect cardiac activity. Peptides 33, 230-239.

Sha, K., Conner, W. C., Choi, D. Y., and Park, J. H. (2012). Characterization expression, and evolutionary aspects of Corazonin neuropeptide and its receptor from the House Fly, Musca domestica (Diptera: Muscidae). Gene 497, 191-199.

Shafer, O. T., Kim, D. J., Dunbar-Yaffe, R., Nikolaev, V. O., Lohse, M. J., and Taghert, P. H. (2008). Widespread receptivity to neuropeptide PDF throughout the neuronal circadian clock network of Drosophila revealed by real-time cyclic AMP imaging. Neuron 58, 223-237.

Shen, P., and Cai, H. N. (2001). Drosophila neuropeptide F mediates integration of chemosensory stimulation and conditioning of the nervous system by food. J. Neurobiol. $47,16-25$.

Shi, Y., Huang, H., Deng, X., He, X., Yang, J., Yang, H., et al. (2011). Identification and functional characterization of two orphan G-protein-coupled receptors for adipokinetic hormones from silkworm Bombyx mori. J. Biol. Chem. 286, 42390-42402.

Shohat-Ophir, G., Kaun, K. R., Azanchi, R., Mohammed, H. and Heberlein, U. (2012). Sexual deprivation increases ethanol intake in Drosophila. Science 335, 1351-1355.

Siegert, K. J. (1999). Locust corpora cardiaca contain an inactive adipokinetic hormone. FEBS Lett. $447,237-240$.

Simonet, G., Poels, J., Claeys, I., Van Loy, T., Franssens, V., De Loof, A., et al. (2004). Neuroendocrinological and molecular aspects of insect reproduction. J. Neuroendocrinol. 16, 649-659.

Siviter, R. J., Coast, G. M., Winther, A. M., Nachman, R. J., Taylor, C. A., Shirras, A. D., et al. (2000).
Expression and functional characterization of a Drosophila neuropeptide precursor with homology to mammalian preprotachykinin A. J. Biol. Chem. 275, 23273-23280.

Söderberg, J. A. E., Carlsson, M. A., and Nässel, D. R. (2012). Insulin-producing cells in the Drosophila brain also express satiety-inducing cholecystokininlike peptide, drosulfakinin. Front. Endocrinol. (Lausanne) 3:109. doi 10.3389/fendo.2012.00109

Spit, J., Badisco, L., Verlinden, H., Van Wielendaele, P., Zels, S., Dillen, S., et al. (2012). Peptidergic control of food intake and digestion in insects. Can. J. Zool. 90, 489-506.

Stables, J., Green, A., Marshall, F., Fraser, N., Knight, E., Sautel, M. et al. (1997). A bioluminescent assay for agonist activity at potentially any G-protein-coupled receptor. Anal. Biochem. 252, 115-126.

Stafflinger, E., Hansen, K. K., Hauser, F., Schneider, M., Cazzamali, G., Williamson, M., et al. (2008). Cloning and identification of an oxytocin/vasopressin-like receptor and its ligand from insects. Proc. Natl. Acad. Sci. U.S.A. 105, 3262-3267.

Staljanssens, D., Azari, E. K., Christiaens, O., Beaufays, J., Lins, L., Van Camp, J., et al. (2011). The CCK(-like) receptor in the animal kingdom: functions, evolution and structures. Peptides 32, 607-619.

Stanek, D. M., Pohl, J., Crim, J. W., and Brown, M. R. (2002). Neuropeptide $\mathrm{F}$ and its expression in the yellow fever mosquito, Aedes aegypti. Peptides 23, 1367-1378.

Stangier, J., Hilbich, C., Beyreuther, K., and Keller, R. (1987). Unusual cardioactive peptide (CCAP) from pericardial organs of the shore crab Carcinus maenas. Proc. Natl. Acad. Sci. U.S.A. 84, 575-579.

Stangier, J., Hilbich, C., and Keller, R. (1989). Occurrence of crustacean cardioactive peptide (CCAP) in the nervous system of an insect, Locusta migratoria. J. Comp. Physiol. B 159, 5-11.

Starratt, A. N., and Brown, B. E. (1975) Structure of the pentapeptide proctolin, a proposed neurotransmitter in insects. Life Sci. 17, 1253-1256.

Staubli, F., Jørgensen, T. J. D., Cazzamali, G., Williamson, M. Lenz, C., Søndergaard, L., et al. (2002). Molecular identification of the insect adipokinetic hormone receptors. Proc. Natl. Acad. Sci. U.S.A. 99, 3446-3451.

Stay, B. (2000). A review of the role of neurosecretion in the control of juvenile hormone synthesis: a tribute to Berta Scharrer. Insect Biochem. Mol. Biol. 30, 653-662.

Stay, B., and Tobe, S. S. (2007). The role of allatostatins in juvenile hormone synthesis in insects and crustaceans. Annu. Rev. Entomol. 52, 277-299.

Sterkel, M., Riccillo, F. L., and Ronderos, J. R. (2010). Cardioacceleratory and myostimulatory activity of allatotropin in Triatoma infestans. Comp. Biochem. Physiol. A Mol. Integr. Physiol. 155, 371-377.

Sterkel, M., Oliveira, P. L., Urlaub, H., Hernandez-Martinez, S., RiveraPomar, R., and Ons, S. (2012). OKB, a novel family of braingut neuropeptides from insects. Insect Biochem. Mol. Biol. 42, 466-473.

Stone, J. V., Mordue, W., Batley, K. E., and Morris, H. R. (1976). Structure of locust adipokinetic hormone, a neurohormone that regulates lipid utilization during flight. Nature 263 , 207-211.

Sudo, S., Kuwabara, Y., Park, J. I., Hsu, S. Y., and Hsueh, A. J. (2005). Heterodimeric fly glycoprotein hormone-alpha2 (GPA2) and glycoprotein hormone-beta5 (GPB5) activate fly leucine-rich repeatcontaining G protein-coupled receptor-1 (DLGR1) and stimulation of human thyrotropin receptors by chimeric fly GPA2 and human GPB5. Endocrinology 146, 3596-3604.

Taghert, P. H., and Nitabach, M. N. (2012). Peptide neuromodulation in invertebrate model systems. Neuron 76, 82-97.

Talsma, A. D., Christov, C. P., TerrienteFelix, A., Linneweber, G. A., Perea, D., Wayland, M., et al. (2012). Remote control of renal physiology by the intestinal neuropeptide pigment-dispersing factor in Drosophila. Proc. Natl. Acad. Sci. U.S.A. 109, 12177-12182.

Tanaka, Y., Hua, Y., Roller, L., and Tanaka, S. (2002). Corazonin reduces the spinning rate in the silkworm, Bombyx mori. J. Insect Physiol. 48, 707-714.

Tawfik, A. I., Tanaka, S., De Loof, A., Schoofs, L., Baggerman, G., Waelkens, E., et al. (1999). Identification of the gregarizationassociated dark-pigmentotropin in locusts through an albino mutant. Proc. Natl. Acad. Sci. U.S.A. 96 7083-7087.

Taylor, C. A., Winther, A. M., Siviter, R. J., Shirras, A. D., Isaac, R E., and Nässel, D. R. (2004). Identification of a proctolin preprohormone gene (Proct) of Drosophila melanogaster: expression and 
predicted prohormone processing. J. Neurobiol. 58, 379-391.

Teal, P. E., Meredith, J. A., and Nachman, R. J. (1999). Development of amphiphylic mimics of insect neuropeptides for pest control. Ann. N.Y. Acad. Sci. 897, 348-360.

Te Brugge, V., Ianowski, J. P., and Orchard, I. (2009). Biological activity of diuretic factors on the anterior midgut of the blood-feeding bug, Rhodnius prolixus. Gen. Comp. Endocrinol. 162, 105-112.

Te Brugge, V., Paluzzi, J. P., Schooley, D. A., and Orchard, I. (2011). Identification of the elusive peptidergic diuretic hormone in the blood-feeding bug Rhodnius prolixus: a CRF-related peptide. J. Exp. Biol. 214, 371-381.

Terhzaz, S., O'Connell, F. C., Pollock, V. P., Kean, L., Davies, S. A., Veenstra, J. A., et al. (1999). Isolation and characterization of a leucokinin-like peptide of Drosophila melanogaster. J. Exp. Biol. 202( $\mathrm{Pt} 24)$, 3667-3676.

Terhzaz, S., Rosay, P., Goodwin, S. F., and Veenstra, J. A. (2007). The neuropeptide SIFamide modulates sexual behavior in Drosophila. Biochem. Biophys. Res. Commun. 352, 305-310.

Terhzaz, S., Cabrero, P., Robben, J. H., Radford, J. C., Hudson, B. D., Milligan, G., et al. (2012). Mechanism and function of Drosophila capa GPCR: a desiccation stress-responsive receptor with functional homology to human neuromedinU receptor. PLoS ONE 7:e29897. doi: 10.1371/journal.pone.0029897

Truman, J. W. (1996). Ecdysis control sheds another layer. Science 271, 40-41.

Ulens, C., Daenens, P., and Tytgat, J. (1999). The dual modulation of GIRK1/GIRK2 channels by opioid receptor ligands. Eur. J. Pharmacol. 385, 239-245.

Urnov, F. D., Rebar, E. J., Holmes, M. C., Zhang, H. S., and Gregory, P. D. (2010). Genome editing with engineered zinc finger nucleases. Nat. Rev. Genet. 11, 636-646.

Van Hiel, M. B., Van Loy, T., Poels, J., Vandersmissen, H. P., Verlinden, H., Badisco, L., et al. (2010). Neuropeptide receptors as possible targets for development of insect pest control agents. Adv. Exp. Med. Biol. 692, 211-226.

Van Hiel, M. B., Vandersmissen, H. P., Van Loy, T., and Vanden Broeck, J. (2012). An evolutionary comparison of leucine-rich repeat containing G protein-coupled receptors reveals a novel LGR subtype. Peptides 34, 193-200.

Van Loy, T., Vandersmissen, H. P., Poels, J., Van Hiel, M. B., Verlinden, H., and Vanden Broeck, J. (2010). Tachykinin-related peptides and their receptors in invertebrates: a current view. Peptides 31, 520-524.

Van Wielendaele, P., Dillen, S., Marchal, E., Badisco, L., and Vanden Broeck, J. (2012). CRF-like diuretic hormone negatively affects both feeding and reproduction in the desert locust, Schistocerca gregaria. PLoS ONE 7:e31425. doi: 10.1371/ journal.pone.0031425

Vanden Broeck, J. (1996). G-proteincoupled receptors in insect cells. Int Rev. Cytol. 164, 189-268.

Vanden Broeck, J. (2001). Insect G protein-coupled receptors and signal transduction. Arch. Insect Biochem. Physiol. 48, 1-12.

Vanden Broeck, J., Poels, J., Simonet, G., Dicksens, L., and De Loof, A (1998). Identification of $\mathrm{G}$ proteincoupled receptors in insect cells. Ann. N.Y. Acad. Sci. 839, 123-128.

Vargas, M. A., Luo, N., Yamaguchi, A., and Kapahi, P. (2010). A role for S6 kinase and serotonin in postmating dietary switch and balance of nutrients in D. melanogaster. Curr. Biol. 20, 1006-1011.

Večeřa, J., Krishnan, N., Alquicer, G., Kodrík, D., and Socha, R. (2007). Adipokinetic hormone-induced enhancement of antioxidant capacity of Pyrrhocoris apterus hemolymph in response to oxidative stress. Comp. Biochem. Physiol. C Toxicol. Pharmacol. 146, 336-342.

Veelaert, D., Schoofs, L., Verhaert, P., and De Loof, A. (1997). Identification of two novel peptides from the central nervous system of the desert locust, Schistocerca gregaria. Biochem. Biophys. Res. Commun. 241, 530-534.

Veenstra, J. A. (1989). Isolation and structure of corazonin, a cardioactive peptide from the American cockroach. FEBS Lett. 250, 231-234.

Veenstra, J. A. (2009a). Allatostatin C and its paralog allatostatin double C: the arthropod somatostatins. Insect Biochem. Mol. Biol. 39, 161-170.

Veenstra, J. A. (2009b). Does corazonin signal nutritional stress in insects? Insect Biochem. Mol. Biol. $39,755-762$.

Veenstra, J. A. (2010). What the loss of the hormone neuroparsin in the melanogaster subgroup of Drosophila can tell us about its function. Insect Biochem. Mol. Biol. 40, 354-361.
Veenstra, J. A., Lehman, H. K., and Davis, N. T. (1994). Allatotropin is a cardioacceleratory peptide in Manduca sexta. J. Exp. Biol. 188 347-354.

Veenstra, J. A., Rodriguez, L., and Weaver, R. J. (2012). Allatotropin, leucokinin and AKH in honey bees and other Hymenoptera. Peptides $35,122-130$.

Verleyen, P., Huybrechts, J., Sas, F., Clynen, E., Baggerman, G., De Loof, A., et al. (2004a). Neuropeptidomics of the grey flesh fly, Neobellieria bullata. Biochem. Biophys. Res. Commun. 316, 763-770.

Verleyen, P., Huybrechts, J., Baggerman, G., Van Lommel, A., De Loof, A., and Schoofs, L. (2004b). SIFamide is a highly conserved neuropeptide: a comparative study in different insect species. Biochem. Biophys. Res. Commun. 320, 334-341.

Verleyen, P., Huybrechts, J., and Schoofs, L. (2009). SIFamide illustrates the rapid evolution in Arthropod neuropeptide research. Gen. Comp. Endocrinol. 162, 27-35.

Verlinden, H., Badisco, L., Marchal, E. Van Wielendaele, P., and Vanden Broeck, J. (2009). Endocrinology of reproduction and phase transition in locusts. Gen. Comp. Endocrinol. $162,79-92$.

Verlinden, H., Vleugels, R., Marchal, E., Badisco, L., Pfluger, H. J., Blenau, W., et al. (2010). The role of octopamine in locusts and other arthropods. J. Insect Physiol. 56, 854-867.

Vilaplana, L., Pascual, N., Perera, N., Leira, D., and Bellés, X. (2008). Antifeeding properties of myosuppressin in a generalist phytophagous leafworm, Spodoptera littoralis (Boisduval). Regul. Pept. $148,68-75$.

Vitt, U. A., Hsu, S. Y., and Hsueh, A. J. (2001). Evolution and classification of cystine knotcontaining hormones and related extracellular signaling molecules. Mol. Endocrinol. 15, 681-694.

Vosko, A. M., Schroeder, A., Loh, D. H., and Colwell, C. S. (2007) Vasoactive intestinal peptide and the mammalian circadian system. Gen Comp. Endocrinol. 152, 165-175.

Vuerinckx, K., Verlinden, H., Lindemans, M., Broeck, J. V., and Huybrechts, R. (2011). Characterization of an allatotropinlike peptide receptor in the red flour beetle, Tribolium castaneum. Insect Biochem. Mol. Biol. 41, 815-822.

Wang, C., Chin-Sang, I., and Bendena, W. G. (2012). The FGLamide-allatostatins influence foraging behavior in Drosophila melanogaster. PLoS ONE 7:e36059. doi: 10.1371/journal.pone.0036059

Wasielewski, O., and Skonieczna, M. (2008). Pleiotropic effects of the neuropeptides CCAP and myosuppressin in the beetle, Tenebrio molitor L. J. Comp. Physiol. B 178, 877-885.

Weaver, R. J., and Audsley, N. (2008). Neuropeptides of the beetle, Tenebrio molitor identified using MALDI-TOF mass spectrometry and deduced sequences from the Tribolium castaneum genome. Peptides 29, 168-178.

Weaver, R. J., and Audsley, N. (2009). Neuropeptide regulators of juvenile hormone synthesis: structures, functions, distribution, and unanswered questions. Ann. N.Y. Acad. Sci. 1163, 316-329.

Weaver, R. J., Freeman, Z. A., Pickering, M. G., and Edwards, J. P. (1994) Identification of two allatostatins from the CNS of the cockroach Periplaneta americana: Novel members of a family of neuropeptide inhibitors of insect juvenile hormone biosynthesis. Comp. Biochem. Physiol. C Pharmacol. Toxicol. Endocrinol. 107, 119-127.

Weaver, R. J., Marco, H. G., Simek, P., Audsley, N., Clark, K. D., and Gäde, G. (2012). Adipokinetic hormones (AKHs) of sphingid Lepidoptera, including the identification of a second M. sexta AKH. Peptides 34, 44-50.

Wegener, C., Herbert, Z., Eckert, M., and Predel, R. (2002). The periviscerokinin (PVK) peptide family in insects: evidence for the inclusion of $\mathrm{CAP}(2 \mathrm{~b})$ as a PVK family member. Peptides 23, 605-611.

Wegener, C., Reinl, T., Jänsch, L., and Predel, R. (2006). Direct mass spectrometric peptide profiling and fragmentation of larval peptide hormone release sites in Drosophila melanogaster reveals tagma-specific peptide expression and differential processing. J. Neurochem. 96, 1362-1374.

Wei, Z., Baggerman, G., Nachman, J., Goldsworthy, G., Verhaert, P., De Loof, A., et al. (2000). Sulfakinins reduce food intake in the desert locust, Schistocerca gregaria. J. Insect Physiol. 46, 1259-1265.

Wen, T., Parrish, C. A., Xu, D., Wu, Q., and Shen, P. (2005). Drosophila neuropeptide $\mathrm{F}$ and its receptor, NPFR1, define a signaling pathway that acutely modulates alcohol sensitivity. Proc. Natl. Acad. Sci. U.S.A. 102, 2141-2146.

Wen, Z., Gulia, M., Clark, K. D., Dhara, A., Crim, J. W., Strand, M. R., et al. (2010). Two insulin-like peptide 
family members from the mosquito Aedes aegypti exhibit differential biological and receptor binding activities. Mol. Cell. Endocrinol. 328, 47-55.

Wesolowska, N., and Rong, Y. S. (2010). The past, present and future of gene targeting in Drosophila. Fly (Austin) 4, 53-59.

West, A. P., Llamas, L. L., Snow, P. M., Benzer, S., and Bjorkman, P. J. (2001). Crystal structure of the ectodomain of Methuselah, a Drosophila G protein-coupled receptor associated with extended lifespan. Proc. Natl. Acad. Sci. U.S.A. 98, 3744-3749.

Wheeler, D. E., Buck, N., and Evans, J. D. (2006). Expression of insulin pathway genes during the period of caste determination in the honey bee, Apis mellifera. Insect Mol. Biol. $15,597-602$.

Wicher, D., Agricola, H., Sohler, S., Gundel, M., Heinemann, S. H., Wollweber, L., et al. (2006a). Differential receptor activation by cockroach adipokinetic hormones produces differential effects on ion currents, neuronal activity, and locomotion. J. Neurophysiol. 95, 2314-2325.

Wicher, D., Agricola, H., Schonherr, R., Heinemann, S. H., and Derst, C. (2006b). TRPgamma channels are inhibited by cAMP and contribute to pacemaking in neurosecretory insect neurons. J. Biol. Chem. 281, 3227-3236.

Wicher, D., Derst, C., Gautier, H., Lapied, B., Heinemann, S. H., and Agricola, H. (2007). The satiety signaling neuropeptide perisulfakinin inhibits the activity of central neurons promoting general activity. Front. Cell. Neurosci. 1:3. doi: 10.3389/neuro.03.003.2007

Williamson, M., Lenz, C., Winther, A. M., Nässel, D. R., and Grimmelikhuijzen, C. J. P. (2001). Molecular cloning, genomic organization, and expression of a C-type (Manduca sexta-type) allatostatin preprohormone from Drosophila melanogaster. Biochem. Biophys. Res. Commun. 282, 124-130.

Woodhead, A. P., Stay, B., Seidel, S. L., Khan, M. A., and Tobe, S. S. (1989). Primary structure of four allatostatins: neuropeptide inhibitors of juvenile hormone synthesis. Proc. Natl. Acad. Sci. U.S.A. 86, 5997-6001.

Woodhead, A. P., Khan, M. A., Stay, B., and Tobe, S. S. (1994). Two new allatostatins from the brains of Diploptera punctata. Insect Biochem. Mol. Biol. 24, 257-263.

Wu, Q., Wen, T., Lee, G., Park, J. H., Cai, H. N., and Shen, P. (2003). Developmental control of foraging and social behavior by the Drosophila neuropeptide Y-like system. Neuron 39, 147-161.

Wu, Q., Zhao, Z., and Shen, P. (2005a). Regulation of aversion to noxious food by Drosophila neuropeptide Y- and insulin-like systems. Nat. Neurosci. 8, 1350-1355.

Wu, Q., Zhang, Y., Xu, J., and Shen, P. (2005b). Regulation of hungerdriven behaviors by neural ribosomal S6 kinase in Drosophila. Proc. Natl. Acad. Sci. U.S.A. 102, 13289-13294.

Würden, S., and Homberg, U. (1995). Immunocytochemical mapping of serotonin and neuropeptides in the accessory medulla of the locust, Schistocerca gregaria. J. Comp. Neurol. 362, 305-319.

Xu, J., Li, M., and Shen, P. (2010). A G-protein-coupled neuropeptide Y-like receptor suppresses behavioral and sensory response to multiple stressful stimuli in Drosophila. J. Neurosci. 30, 2504-2512.

Yagi, K. J., Kwok, R., Chan, K. K., Setter, R. R., Myles, T. G., Tobe, S. S., et al. (2005). Phe-Gly-Leu-amide allatostatin in the termite Reticulitermes flavipes: Content in brain and corpus allatum and effect on juvenile hormone synthesis. J. Insect Physiol. 51, 357-365.

Yamanaka, N., Yamamoto, S., Žitňan, D., Watanabe, K., Kawada, T., Satake, H., et al. (2008). Neuropeptide receptor transcriptome reveals unidentified neuroendocrine pathways. PLoS ONE 3:e3048. doi: 10.1371/journal.pone.0003048

Yamanaka, N., Hua, Y. J., Roller, L., Spalovska-Valachova, I., Mizoguchi, A., Kataoka, H., et al. (2010). Bombyx prothoracicostatic peptides activate the sex peptide receptor to regulate ecdysteroid biosynthesis. Proc. Natl. Acad. Sci. U.S.A. 107, 2060-2065.

Yamanaka, N., Roller, L., Žitňan, D., Satake, H., Mizoguchi, A., Kataoka, H., et al. (2011). Bombyx orcokinins are brain-gut peptides involved in the neuronal regulation of ecdysteroidogenesis. J. Comp. Neurol. 519, 238-246.

Yapici, N., Kim, Y. J., Ribeiro, C., and Dickson, B. J. (2008). A receptor that mediates the post-mating switch in Drosophila reproductive behaviour. Nature 451, 33-37.

Yoshiura, S., Ohta, N., and Matsuzaki, F. (2012). Tre1 GPCR signaling orients stem cell divisions in the Drosophila central nervous system. Dev. Cell 22, 79-91.

Yu, D., Akalal, D.-B. G., and Davis, R. L. (2006). Drosophila $\alpha / \beta$ mushroom body neurons form a branchspecific, long-term cellular memory trace after spaced olfactory conditioning. Neuron 52, 845-855.

Zandawala, M. (2012). Calcitonin-like diuretic hormones in insects. Insect Biochem. Mol. Biol. 42, 816-825.

Zandawala, M., Lytvyn, Y., Taiakina, D., and Orchard, I. (2012). Cloning of the CDNA, localization, and physiological effects of FGLamide-related allatostatins in the blood-gorging bug, Rhodnius prolixus. Insect Biochem. Mol. Biol. 42, 10-21.

Zhao, Y., Bretz, C. A., Hawksworth, S. A., Hirsh, J., and Johnson, E. C. (2010). Corazonin neurons function in sexually dimorphic circuitry that shape behavioral responses to stress in Drosophila. PLoS ONE 5:e9141. doi: 10.1371/journal.pone.0009141

Zhu, C., Huang, H., Hua, R., Li, G., Yang, D., Luo, J., et al. (2009). Molecular and functional characterization of adipokinetic hormone receptor and its peptide ligands in Bombyx mori. FEBS Lett. 583, 1463-1468.

Zhu, W., Verhaert, P., Shaw, C., Maule, A., De Loof, A., and Vaudry, H. (1998). NPF immunolocalization in cockroaches and locusts: Comparison of antisera to beetle, tapeworm, and pig NPY/NPF-type peptides. Ann. N.Y. Acad. Sci. 839, 625-627.

Ziegler, R., Jasensky, R. D., and Morimoto, H. (1995). Characterization of the adipokinetic hormone receptor form the fat body of Manduca sexta. Regul. Pept. 57, 329-338.

Ziegler, R., Isoe, J., Moore, W., Riehle, M. A., and Wells, M. A. (2011). The putative AKH receptor of the tobacco hornworm, Manduca sexta, and its expression. J. Insect Sci. 11, 40.

Zoephel, J., Reiher, W., Rexer, K H., Kahnt, J., and Wegener, C. (2012). Peptidomics of the agriculturally damaging larval stage of the cabbage root fly Delia radicum (Diptera: Anthomyiidae).
PLoS ONE 7:e41543. doi: 10.1371/journal.pone.0041543

Zupanc, G. K. (1996). Peptidergic transmission: from morphological correlates to functional implications. Micron 27, 35-91.

Žitňan, D., Hollar, L., Spalovská, I., Takáč, P., Žitňanová, I., Gill, S. S., et al. (2002). Molecular cloning and function of ecdysis-triggering hormones in the silkworm Bombyx mori. J. Exp. Biol. 205, 3459-3473.

Žitňan, D., Ross, L. S., Žitňanová, I., Hermesman, J. L., Gill, S. S., and Adams, M. E. (1999). Steroid induction of a peptide hormone gene leads to orchestration of a defined behavioral sequence. Neuron 23, 523-535.

Žitňan, D., Kim, Y. J., Žitňanová, I., Roller, L., and Adams, M. E. (2007). Complex steroid-peptidereceptor cascade controls insect ecdysis. Gen. Comp. Endocrinol. 153, 88-96.

Žitňan, D., Žitňanová, I., Spalovská, I., Takáè, P., Park, Y., and Adams, M. E. (2003). Conservation of ecdysis-triggering hormone signalling in insects. J. Exp. Biol. 206, 1275-1289.

Conflict of Interest Statement: The authors declare that the research was conducted in the absence of any commercial or financial relationships that could be construed as a potential conflict of interest.

Received: 01 October 2012; paper pending published: 11 October 2012; accepted: 14 November 2012; published online: 30 November 2012.

Citation: Caers J, Verlinden H, Zels $S$, Vandersmissen HP, Vuerinckx K and Schoofs L (2012) More than two decades of research on insect neuropeptide GPCRs: an overview. Front. Endocrin. 3:151. doi: 10.3389/fendo. 2012.00151

This article was submitted to Frontiers in Neuroendocrine Science, a specialty of Frontiers in Endocrinology.

Copyright (c) 2012 Caers, Verlinden, Zels, Vandersmissen, Vuerinckx and Schoofs. This is an open-access article distributed under the terms of the Creative Commons Attribution License, which permits use, distribution and reproduction in other forums, provided the original authors and source are credited and subject to any copyright notices concerning any third-party graphics etc. 